PROPAGANDA, MASCULINITY, AND

THE FRENCH INTERWAR NOVEL

A Dissertation
presented to
the Faculty of the Graduate School
at the University of Missouri-Columbia
In Partial Fulfillment
of the Requirements for the Degree
Doctor of Philosophy
Dr. Valerie Kaussen, Dissertation Supervisor
MAY 2021
COURTNEY WEBSTER


(C) Copyright by Courtney L Webster 2021

All Rights Reserved 
The undersigned, appointed by the dean of the Graduate School, have examined the dissertation entitled

\section{PROPAGANDA, MASCULINITY, AND THE FRENCH INTERWAR NOVEL} presented by Courtney L Webster, a candidate for the degree of Doctor of Philosophy, and certify that, in their opinion, it is worthy of acceptance.

Dr. Valerie Kaussen

Dr. Megan Moore

Dr. Mary Jo Muratore

Dr. Carol Lazzaro-Weis

Dr. Ilyana Karthas 


\section{DEDICATION}

For my family who never doubted me, not even once. Thank you. 


\section{ACKNOWLEDGEMENTS}

I am grateful to all of those with whom I have had the pleasure to work during this project. Each of the members of my Dissertation Committee has provided me extensive personal and professional guidance and taught me a great deal about literature, history, research and life in general.

I would like to thank Dr. Valerie Kaussen for her unwavering support and dedication to this project. I would also like to express my appreciation for the dedication and work of my Dissertation Committee, your thoughtful contributions and critiques rendered this undertaking less arduous. Lastly, I would like to thank the Department of Romance Languages and Literature at the University of Missouri-Columbia for the opportunity and flexibility to work on what ultimately became an interdisciplinary project. 


\section{TABLE OF CONTENTS}

ACKNOWLEDGEMENTS

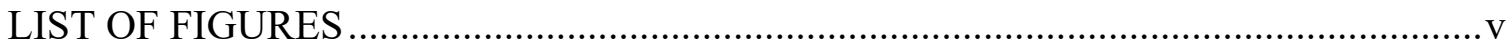

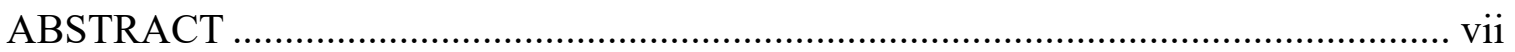

PROPAGANDA, MASCULINITY, AND THE FRENCH INTERWAR NOVEL ........... 1

The Advertising Poster, Propaganda, and the Interwar and Wartime Novel ..........5

Visual Culture and Literature: Interdisciplinary Methods................................ 9

The Disruptions of the Interwar/Wartime Period: Historical Context .................. 11

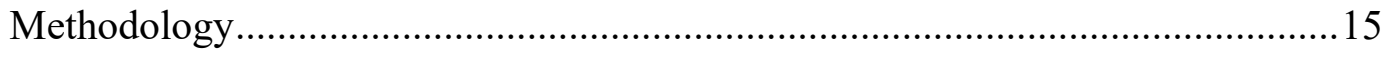

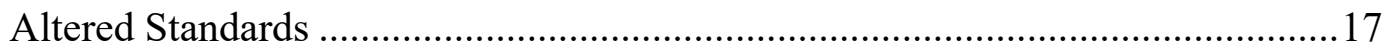

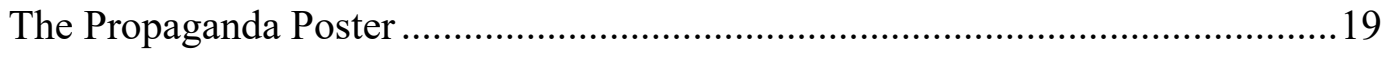

Gendered Practice and War ........................................................................2 23

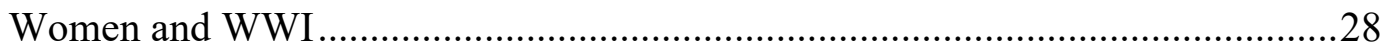

Masculine Practice, the Conseil de Revision, and Physical Culture ......................32

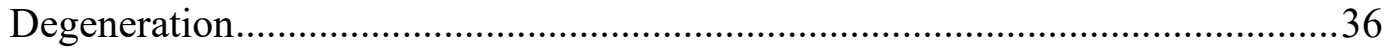

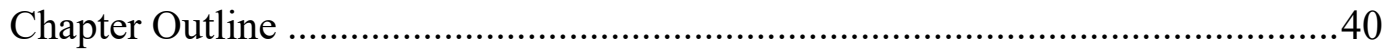

Chapter

1. ANDRÉ GIDE AND PRE-WWI MASCULINITY: L'IMMORALISTE ..............45

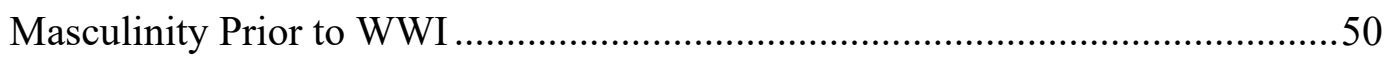

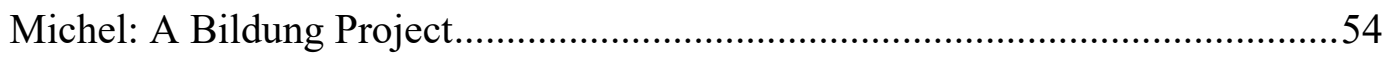

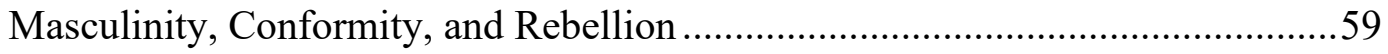

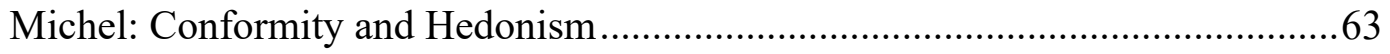

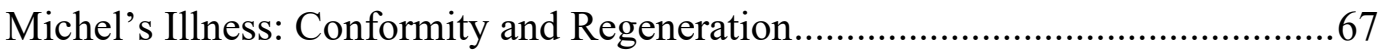

Propagandized Masculinity ..................................................................... 73 
2. COLETTE AND HER MUSE OF MASCULINITY: CHÉRI AND LA FIN DE

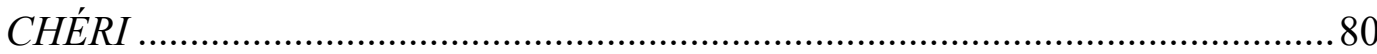

Belle Epoque Chéri vs. Propagandized Masculinity …………………………........ 85

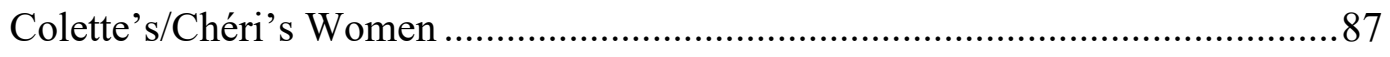

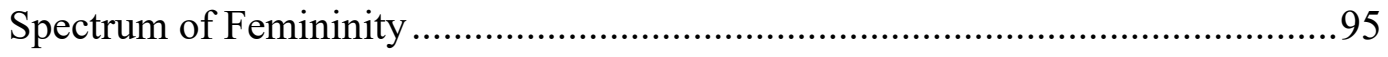

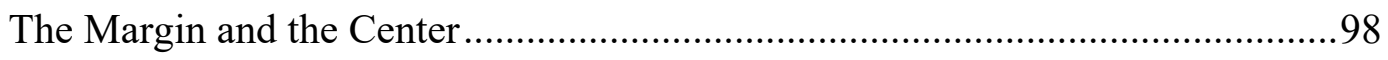

3. THE ANTI-HERO AND THE REJECTION OF SOLDIERING AS

MASCULINITY IN CÉLINE'S VOYAGE AU BOUT DE LA NUIT .................. 101

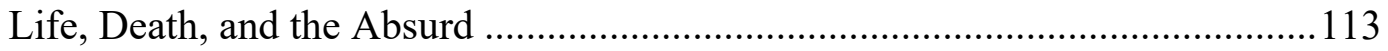

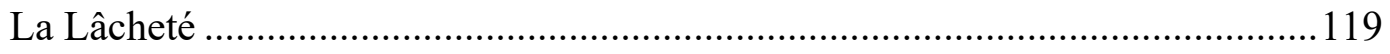

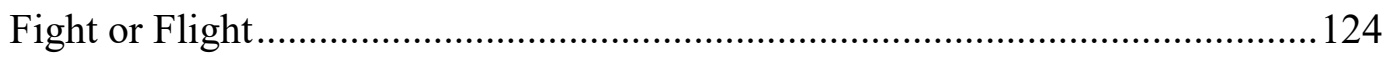

Hallucinations: The Galley Ship and Bardamu .................................................. 126

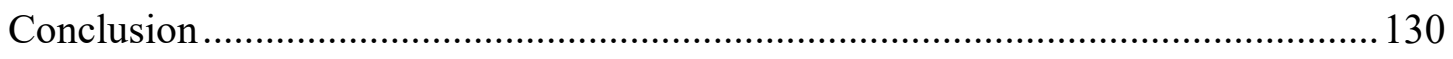

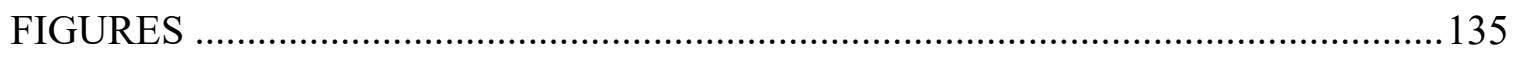

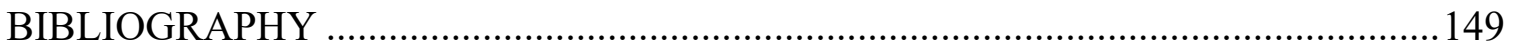

VITA 


\section{LIST OF FIGURES}

Figure

Page

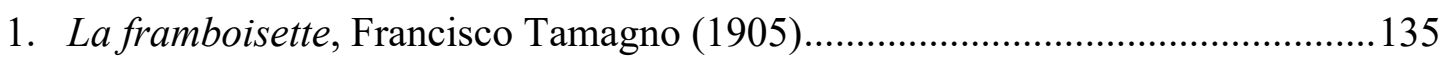

2. France-Champagne, Pierre Bonnard (1891) ................................................ 135

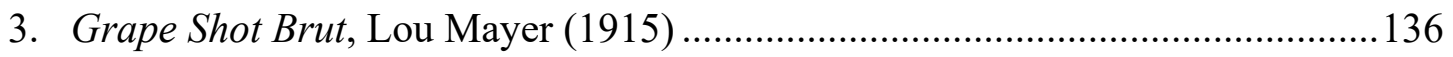

4. Quinquina Dubonnet Aperitif, Jules Chèret (1895) ........................................ 136

5. Postcard published by "Le Rire Rouge” for Christmas 1914 ............................. 137

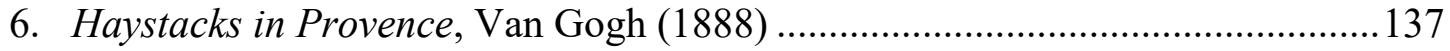

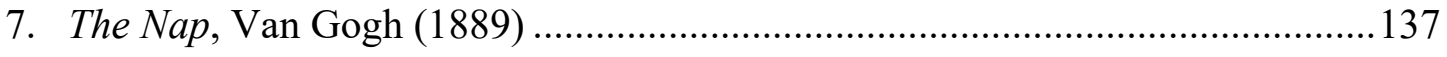

8.

9.

10. "The sunrise illuminates the trench where the standing soldier dreams of victory and his home. So that he can assure one and return to the other. Subscribe to the 3rd National Defense Loan." (1917) ..................................... 138

11. 4th National Loan/Subscribe/Central Society of Banks of Province (1918)....... 139

12. Commercial Credit of France/Subscribe for Victory and for the Triumph of Liberty - 4th National Defense Loan (1918)

13. Absinthe Parisienne/“Drink Then, You Will See After,” Giles-Didot \& Malteste (1896).

14.

15. Conseil de Révision. Anti-conseil de révision cartoon

16. Le conseil de révision/ "The review board. Honoré Daumier (1842)

17. Bon pour les Filles/“Good for Women”.

18. Bon pour les Service/"Good for Service”.

19. Le Rire/“At the Review Board,” Paul Leonnec (1895)

20. Méthode Desbonnet/Results Guaranteed in 26 Lessons (1904) 142 
21. La Baïonnette, 29 November (1917) 143

22. La Culture Physique (1904), "Régénération du Snob," satire 143

23. Le Rêve. The Dream, Nug 342 (1916) 144

24. "Third National Defense Loan - Subscribe!" "For France who fights! For each little one who grows each day! Auguste Laroux (1917).

25. "Request for Godmother - Young Soldier, hardly bearded would like to correspond with a young godmother possessing treasures of love to share Respond," Xavier Sager (1915).

26. "The repeating rifle, it's good for repopulation," Rex 2100 (1915), Ville de Paris - Bibliothèque Marguerite Durand

27. "Société Marseillaise de Crédit," "At the call of Rouget de L'isle Subscribe to the Liberation Loan" (1918), Carlu, Jacques, Artist. Société Marseillaise de Crédit. Souscrivez á l'Emprunt de la Libération. [Paris: Devambez] Photograph. 145

28. La rouquine - Quinquina Dubonnet Apériti/In Every Café, Jules Cheret (1895)

29. Sidonie Gabrielle Colette photographed by Henri Manuel (c. 1909) 146

30. "We will get them!"'/2nd Loan for National Defense/Subscribe, Jules Able Faivre (1916) 146

31. "French Canadians Enlist! England, rampart of our liberty, is menaced. Will we stay indifferent?" A. H. Hider (1915).

32. "If only I was bigger." Boubot (1915)

33. "Cowards! France will not forget!" 148

34. M.D., Parade of troops (1918), Strasbourg (Alsace) 148 35. "July 14th in Paris, 1916, on Avenue Champs Elysees" 148 


\title{
PROPAGANDA, MASCULINITY, AND THE FRENCH INTERWAR NOVEL
}

\author{
Courtney L Webster \\ Dr. Valerie Kaussen, Dissertation Supervisor
}

\begin{abstract}
My dissertation centers on literary representations of non-normative gender performances, the struggle around new gender norms, and the lived realities of gender in pre- and post-World War I- (WWI) era France. The novels discussed in this study, L'Immoraliste (André Gide, 1902), Chéri and La Fin de Chéri (Colette, 1920 and 1926, repectively), and Voyage au bout de la nuit (Céline, 1932) all depict how WWI significantly disrupted French life and troubled gender roles in nearly all environments. The novels that I analyze reveal, in particular, how French manhood became a source of nationalist anxiety in this era, as masculinity was seen as weakened by prior French military defeats and the so-called "excesses" of the belle époque. Using an interdisciplinary approach, the dissertation puts WWI-era novels in dialogue with the visual culture of war propaganda found in French government-sponsored propaganda posters. As I show, propaganda posters heavily promoted heteronormative standards of French masculinity, disseminated images of the ideal French male as physically powerful, courageous, and ready to defend family and nation, and reminded young French men that they carried the weight of defending not only the nation, but the future of French masculinity and the health of the population more broadly. As my study argues, novels by Colette, Gide, Celine, and others call into question WWI propagandized gender norms by imagining alternative gender performances and creating spaces for self-
\end{abstract}


determined gender performances. My dissertation thus argues that novels by Gide, Colette, Céline, and others demonstrate that the normative standards encountered in WWI propaganda were, in fact, fictions that belied the lived realities of gender. 


\section{Propaganda, Masculinity, and the French Interwar Novel}

This dissertation centers on literary representations of non-normative gender performances, the struggle between new norms of masculinity and femininity, and the lived realities of gender in pre- and post-World World War I (WWI) era France. The four novels examined in the chapters that follow all problematize normative masculine hegemony just prior to and during wartime: L'Immoraliste (André Gide, 1902) Voyage au bout de la nuit (Louis Ferdinand Céline, 1932), Chéri and La Fin de Chéri. (Gabrielle Sidonie Colette, 1920 and 1926 respectively). Further, while calling into question normative masculinity, I show how each novel works to cast or recast into doubt the traditional ideas of gender $=$ sex. In these literary deconstructions of gender $=$ sex, and standards of masculinity and femininity, the non-normative becomes normalized, shifting from the margins into the center.

My project follows in the footsteps of Margaret Higonnet, who wrote,

If popular culture insisted on the anchoring polarities of gender, the literature of war allowed more latitude for probing definitions of masculinity and femininity. Both male and female authors challenged prevailing myths about their sex. ${ }^{1}$

Indeed, I compare these WWI era literary representations of masculinity and gender more broadly to normative representations of gender as they are depicted in the popular visual culture of the period: advertising and war propaganda posters. I explore how advertising and especially war propaganda posters reproduced the gendered norms that the period's literary works call into question, sometimes directly referring to these images themselves.

\footnotetext{
${ }^{1}$ Margaret R. Higonnet, Behind the Lines: Gender and the Two World Wars, 1 st ed. (New Haven: Yale University, 1987), 13.
} 
My dissertation argues that wartime and interwar novels present reality as it was lived and sometimes idealized by soldiers and civilian authors, and further that these writers critiqued the ways the dominant culture represented gendered bodies and identities, the images of which appear in the advertising and propaganda posters of the era, which illustrated and promoted hegemonic ideas about gender in pre-war and wartime. The propaganda poster offered no respite for a coward in the shadow of the war. The portrayed standards of masculinity represented an upstanding French man who did not run from the war, who was not frightened of battle, and who managed heteronormative relationships with a traditional woman.

As the literature of the era shows, in pre- and post-WWI France, dissonant notions about gendered behaviors weighed heavily on the French public. The Franco-Prussian war had nearly cost France its capital city, Paris, and though the Armistice agreement gave the French government some concessions, the Prussian army occupied Paris until France paid off the huge war reparations required as the price of peace. The nation's soul was damaged, and the losses of the war (including the fall of the Second Empire) bred anxiety over the state of French masculinity and femininity. Exemplary of the kind of sounding board that developed in response to these anxieties was the concept of racial or national degeneration, which offered a mitigating explanation for what was understood as the French population's (and thus the nation's) weakness. Concurrently, fears over future conflicts intensified the nationalist agenda, drawing France to examine its faults and seek to restore its national glory by way of altering the behaviors of its men and women. Thus, throughout the wartime period, including the immediate pre- and post-War years, French society was a society at war, which had deep consequences for individual French men 
and women alike: wartime demanded shifts in gender norms, forcing gender and gendered performances into the broader discussion of France's failures and success. The confluence of the French interwar nationalist agenda, the attempt to manage fears over disrupted gender norms, and the perception of the Frenchman's weakness (due to supposed degeneration) gave rise not only to literature that critiques wartime standards but to a new form of art poster.

The propaganda poster was not dissimilar to the pre-war advertising already displayed on French buildings, pushing images traditionally perceived as scandalous to the French viewer. For example, Figures 1, 2, 3, 4, and 13 feature ladies who appear tipsy, caught up in the bubbly and dizzying effects of champagne. There is the more suggestive image of a flapper riding the champagne cork as it flies from her bottle, negotiating a transaction with a male customer. The lovely, direct gaze, careless nature, disheveled coiffure, state of dress and undress, and the nuanced inebriation all speak to formerly private moments in French society. The images of the art poster and their model appeared on the sides of buildings throughout Paris, where they were visible to every passerby, from common to wealthy. The scandalous posters presented images and moments the French traditionally regarded as private, rendering them especially provocative and desensitizing the French public in order to sell a product. ${ }^{2}$

As the larger French public became accustomed to suggestive imagery in public spaces, political, cultural, and governmental institutions adopted the format, adapting it to suit their needs. The calls for allegiance using delicate and discomfiting imagery were well-suited to wartime propaganda. Such imagery sought to encourage soldier support,

\footnotetext{
${ }^{2}$ Hollis Clayson. Painted Love: Prostitution in French Art of the Impressionist Era (Test \& Documents), 1st ed (Los Angeles: Getty Research Institute, 2003).
} 
recruit volunteers, and aid in goods procurement, as well as admonish and disparage or "vilify" various peoples, values, and ideas.

Also part of the conspicuous consumer culture of the Belle Epoque, the war propaganda poster attempted to alter the French public's perception of its obligations and troubles, direct citizens' behaviors, and influence French cultural and social norms. The propaganda poster's methods and means of addressing the public were nearly identical to those employed in advertising posters; only the subject matter had changed. No longer asked to identify with a male bourgeois spectator nor to envy or desire the joyful women depicted in advertisements and thus consume the product necessary to possess her, the public was instead pressured to identify with the nation and to consume the "product" or the idea that the war was desirable, requiring men and women to alter their thoughts and behaviors to accommodate the particular wartime needs. Further, propaganda posters would address as well as soothe the cultural insecurities that arose due to the war, thus tending to a set of insecurities that replaced those addressed by the earlier product advertisements, which involved the economic power and prowess of the male bourgeois subject. In a striking about-face, it is the now the men who are being sold to the public as soldiers (and standards of masculine performance) and no longer the men who are the consumer.

Government control over and military involvement in producing propagandistic images began in August, 1914. Propaganda posters were disseminated, controlled, and censored by The Under-Secretary of State for the Fine Arts, under the general direction of the Section Photographique et Cinématographique de l'Armée. Hence the 
heteronormative, matrimonormative, and Poilu-lauding messages of the posters expressed the positions of both the state and the military. ${ }^{34}$

\section{The Advertising Poster, Propaganda, and the Interwar and Wartime Novel}

The pre-war advertising poster presented suggestive imagery that included a product all but eclipsed by a young lady. Populating the poster were images of young women dressed for parties, hair lightly mussed, their outfits slightly askew, alluding to their state of inebriation and thus, likely, their accessibility. According to the marketing strategy, these images sought to incite envy and desire for the product by associating it with the woman pictured. ${ }^{5}$ Once he possessed the product, the assumed male consumer would be enabled to also "get the girl." The advertising poster relied on the commodification of women (selling sex) as well as on a particular definition of feminine allure in this period. The traditional heterosexual relationship is evoked, with the audience or consumer considered to be male and the artwork showing a presumably available young woman. ${ }^{6}$ Objectified in the advertising posters, the young woman becomes the commodity the male audience is seeking, thus reinforcing the traditional heterosexual relationship.

Whereas the advertising poster sought to incite the consumer to desire the lady and her perceived state of joy and carefree inebriation, the propaganda poster used imagery to elicit a desire for soldiering and its support, motivating feelings of duty, pride,

\footnotetext{
${ }^{3}$ Charles Ridel. "Propaganda at Home (France)," in International Encyclopedia of the First World War 1914-1918 (Online, 2021).

${ }^{4}$ Poilu - primary definition is hairy or shaggy with a secondary definition of a WWI French soldier. The usage infers virility and exemplary traditional French masculinity.

${ }^{5}$ Roth, “Advertising/Pornography/Art, 921-47.

${ }^{6}$ Hollis, Painted Love.
} 
and shame, as well as rage and disgust for the nation's enemies (both internal and external). In addition to these sentiments, the propaganda poster introduced a set of normative behaviors for wartime and interwar French men and women. These calculated images advanced a prescribed image of masculinity as virile, upstanding, and physically powerful. Matrimonormative images also play a central role, since the posters leaned heavily on a dichotomous system of complementary genders, patriotism, and patriarchy. ${ }^{7}$

The particular form of masculinity and the gendered behaviors that the WWI era presented as ideal and normative were not invented in nineteen-fourteen; they were part of a longer tradition of visual culture that appeared in government propaganda and also in the free press, especially in satirical newspapers, like Le Rire. As early as eighteen-fortytwo, images appeared in the French press calling the nation's masculinity, particularly for soldiering, into question. The Conseil de Revision, a public event every year until 1873, was a government physical and appraisal of France's young men that judged their aptitude for military readiness. ${ }^{8}$ Increasing failure rates of this assessment lead to further insecurity and doubt in French masculinity. A satirical image concerning the Conseil de Révision by Honoré Daumier (Figure 16;1842) centers its critique on the sorry state of the average French male's body. The image published in Le Rire depicts the emaciated and weakened bodies of young men, stripped down to their pants, who are under scrutiny and appear to be failing, as they are measured and assessed by four frowning government and military officials in suits or full regalia, while a bust of Louis Philippe, "the Citizen King." looks on in the background. Again, in 1895, the artist Paul Leonnec (Figure 19) demonstrates the same fears over inadequacies of the male body in a cartoon that

\footnotetext{
${ }^{7}$ Roberts, Civilization Without Sexes.

${ }^{8}$ I discuss this in more depth on page 38.
} 
appeared on the cover of the Le Rire. In this image, the men represented are once again young, with few if any markers of mature physical masculinity (facial hair; musculature); instead, they appear to be boys, one of whom is knock-kneed. The immature physicality of the young men, who also look nearly identical in their near and complete nudity, contrasts with the group of men who inspect them. The numerous Third Republic officials (eight in all) are all middle-aged, have moustaches, and wear coats bedecked with medals and uniforms that attest to their "earned" power and prestige. The "nation" in this image appears symbolically in the background in the image of the tri-colore and a bust of Marianne. Neither of these cartoons promotes an idea of France's masculine strength; in fact, each insinuates and emphasizes the new recruits' lack of masculinity.

Figures 20 and 22, both dating from 1904, allow us to better surmise what ideal masculine physicality was supposed to look like. These images promote physical activity regimes and the physical culture movement and thus suggest what the French male was perceived to lack and what he needed to do in order to conform to masculine physical norms. The ad for one project to improve the male body, the Méthode Desbonnet (Figure 20 ) and the cartoon in Figure 22 both promote a physical activity regime, based in the physical culture movement, which sought to rehabilitate the weakened French male. ${ }^{9}$ Both images offer a vision of the weak bourgeois male, whose body must be strengthened and transformed. The well-dressed bourgeois men are thin, with curved postures and narrow, sloping shoulders. What these bodies communicate to the viewer is a need for

\footnotetext{
${ }^{9}$ La Méthode Desbonnet - founded by Edmond Desbonnet considered the father of European Physical Culture. He was a trained photographer, wrote books on physical exercise and founded athletic clubs, the first opening in Lille, France in 1885. His "method" consisted of guided physical training to rehabilitate the human form believing that rehabilitating the body was the key to rehabilitating man/woman and their genes.
} 
straight posture, broad and level shoulders, and muscular arms and legs. Governmentsanctioned images of the war period index masculinity according to these same physical norms. The men in Figures 10, 12, and 23 all possess straight posture and level shoulders. Further, Figure 21, discussed in detail in Chapter One, presents the ultimate French masculine ideal, the Poilu. ${ }^{10}$ Additionally, Figures 23, 24, and 25 all depict the expected virility of French masculinity. ${ }^{11}$ Traits associated with virility were physical as well as social. In Figures 23, 24, and 25, good posture, level shoulders, and strength are not all that are depicted. The men present across the three government-sanctioned ads are uniformed, plainly communicating that virile French masculinity serves in the military. Further, the men are illustrated with ladies (who happen to be seeking them or waiting for them) and their children communicating the expectation of heteronormativity.

Despite their flooding public spaces, these images of masculinity found in the press and in wartime propaganda are not fully representative of masculinity or femininity in the period. The artistic opposition to these images, I argue, appears in the inter-war and wartime novel in which divergent, alternative, and self-determined gender performances are the norm. I pursue this argument by determining if the works represent the clash of the visual and literary and, if not, in what ways and through what themes they complement one another. Conversely, I explore whether these two forms of media subvert each other's implied goals and if the novels are reactionary. Though beyond the scope of this study, I touch upon whether the propagandized heteronormativity seen by the authors caused or at least colluded with the conflict leading to war. My thesis leads to

\footnotetext{
${ }^{10}$ See Footnote 4 for a definition of the term.

${ }^{11}$ For a deeper discussion on virility, see Judith Surkis, Sexing the Citizen: Morality and Masculinity in France, 1870-1920, as well as Joan Tumblety, Remaking the Male Body.
} 
the question, did one medium represent part of a cultural movement that catalyzed the other? The advertising poster was a means to elicit sales; in comparison, the propaganda poster was a way to elicit calculated actions, masculine abeyance to soldiering notions, and feminine notions of home-making and child-bearing. The activities of advertisers, propagandists, and writers did not occur independent of one another, and reactions to the hardening of gender roles and the normative standards represented by the propaganda poster are thus apparent in the wartime novel.

\section{Visual Culture and Literature: Interdisciplinary Methods}

The propaganda poster followed the example of the advertising poster, setting forth imagery that would evoke a reaction from the spectator. The government planned the imagery so that viewers would sympathize with the goals of the propaganda. As WWI progressed, the propaganda poster's message and its targeted audience evolved in conformity with the needs of the war effort, moving from soldiers to soldier support to funding. Each of the posters examined addresses one or more of these needs while communicating public relations messages from the French government represented in the language and imagery of normative standards of masculinity and femininity. For example, Figures $5,10,11$, and 12 show the imagery of masculinity shifting from the eager young soldier in the first poster to the weathered, mature soldier of later images.

Many areas of private and public life became fodder for the propaganda poster; however, I do not address all of them in this dissertation. My analysis focuses on sustaining support—financial, moral, and emotional—as represented in posters, ads, and postcards. I analyze the images and ideas depicted in the propaganda poster that concerned and promoted perceived standards for masculinity and femininity and compare 
them to literary works that challenge those standards. I lean heavily on the methodology set forth by John Berger in Ways of Seeing (1977), which supports discussions of imagery in both visual and literary works. Berger writes that "art is a symbiotic relationship in which both image and observer generate meaning." 12 Works of art transmit the social information derived from the artists' experience, yet what is understood is dependent on the viewer who engenders the meaning. Whereas these disparate forms of expression, posters and novels, were no doubt composed for particular reasons or openly stated goals, they nonetheless convey standards of gendered behavior that mark social and cultural acceptability. Both praise or anathematize the prescribed bravery of the French soldier and the demure patience and embrace of child-bearing expected of the French woman. The images and novels not only depict actions and conditions but present critiques of dress, relationships, and comportment to members of the public who view or read them. French propaganda art of this period works to standardize masculine hegemony, normalize matrimonormativity and further communicate masculine domination over French society. By illustrating heteronormative and matrimonormative standards, the propaganda posters inversely or directly problematize non-normative gender. In addition to this problematization, gender and sex were combined into the same constructs, further complicating the process for not only non-normative genders but all citizens in their practice of identity.

Following a Sartrian-inflected model of gender, I suggest that it is "le regard de l'autre" that defines femininity or masculinity. ${ }^{13}$ In the case of poster art, advertising, or

\footnotetext{
12 Prathiba Rai, "Review: Ways of Seeing," The Oxford Culture Review, 2017. https://theoxfordculturereview.com/2017/04/04/review-ways-of-seeing/

13 John Berger. Ways of Seeing: Based on the BBC Television Series (Penguin Books for Art). 1st ed.. London: Penguin Books, 1990.
} 
propaganda, the image functions as the "regard de l'autre" as well as informs viewers on the status of their own regard. The war novel functioned in a similar fashion. Interwar novelists, addressing the same themes and images as the propaganda posters, endeavored to show that, under the "regard de l'autre, "What was considered "otherness" by the government and conventional society was in fact, according to their view, not foreign or different, but instead, dominant. The novelists accomplished this overturning of the normative by using their lived experiences as soldiers, former soldiers, and civilian witnesses of war. This thesis shows the impact that the propaganda poster was intended to have on the interwar spectator, as demonstrated through the reactivity of the war novel. More specifically, I illustrate the social and cultural norms that the propaganda poster urged/proposed as well as the resistance/submission to these norms reflected in interwar novels. $^{14}$

\section{The Disruptions of the Interwar/Wartime Period: Historical Context}

The historical geography of France in the Inter-war period is one of peaks and valleys. Mary-Louise Roberts states that the French worldview as of 1914 was one of stability and security, despite the losses of the Franco-Prussian war. World War I began this same year, and before long, the acres of nightmarish no man's land would overtake farms, cities, and villages. This drastic change to the physical geography of France, caused by four years of warfare on its soil, is mirrored in the social and cultural upheaval experienced in the same period. The changes that had appeared in women's fashion and hairstyle prompted a crisis in gender norms, causing scandal and backlash in regards to

\footnotetext{
${ }^{14}$ See Roberts, Civilization Without Sexes for more information.
} 
femininity.$^{15}$ The cultural tension only increased as the state of masculinity was questioned. ${ }^{16}$ Foregrounded by the Franco-Prussian defeat, followed by WWI, women in the workplace, and the low birth rate, any change to "tradition" was met with opposition. French masculinity, represented by the soldier, was no longer a reliable benchmark for society due to their experiences of hysteria and shell shock. The soldier's counterpart, the heretofore considered complementary French wife and mother, was herself no longer recognizable due to similar wartime challenges and adaptations. These changes due to the disruptions of WWI were seen as a cultural assault rather than an acclimatization. My chosen works are set in this tumultuous period and describe the changes men and women underwent as soldiers and civilians also evidenced in the propaganda imagery. Although they are works of fiction, the unease that resulted from so many changes as well as the changes themselves are recorded in the novels of my study.

The myriad changes the war brought tested both the socially and culturally constructed models of gender roles and sexuality. Warfare upended French life, causing women to take men's places in all manner of employment at the home front. To further complicate matters, French women labored for the Republic under the punitive laws of the Napoleonic Code. The Napoleonic Code, among other things, considered women as "minors," incapable of inheritance, property ownership, and even custody of their own children. ${ }^{17}$ Yet, in France's time of need, women stepped in to keep the country running.

\footnotetext{
${ }^{15}$ See Mary Louise Roberts, "Samson and Delilah Revisited: The Politics of Women's Fashion in 1920's France, The American Historical Review 98, no. 3 (1993) or Adam C. Stanley, Modernizing Tradition: Gender and Consumerism in Interwar France and Germany (Baton Rouge: LSU Press, 2008) for more information.

${ }^{16}$ See Carolyn J. Dean, The Frail Social Body: Pornography, Homosexuality, and Other Fantasies in Interwar France (Berkeley: University of California Press, 2000) for more information.

${ }^{17}$ See Eugen Weber, France, Fin de Siècle (Cambridge: Harvard University Press, 1986) for more information.
} 
The disruptions were not limited to the home front and women's work. Robert A. Nye explains that "changes in one sex provoked adjustments in the other, producing moments of crisis and negotiation." ${ }^{18}$ The traditional hegemonic warrior male became visible as a fragile and mythological creature due to the traumatic nature of modern warfare.

Advances in the technology of warfare eviscerated the French army as well as the ideal of the soldier. Traditional ideas about men and war were altered in that the masculine experience of war was no longer linked to fearlessness and adventure. ${ }^{19}$ French masculinity, which had been built on honor codes and ideals of courage, was disrupted.

When French masculinity was understood to be failing at the front, older men were conscripted. When the conscripts were not enough, masculinity was imported in the form of colonial soldiers, given empty promises of citizenship and validation. ${ }^{20}$ Prior to WWI, urban degeneration had been cited as causing the national weaknesses that allowed the French army to lose control of Paris to Prussian forces. This cause célèbre would not fade away but instead enjoyed renewed support due to the war's hardships and unexpected consequences. As France's birthrate plummeted, there was a further assault on traditional ideas of masculinity. While degeneration was seen as a primary cause for male weakness, the latter also developed a causal relationship with the drop in the birthrate. Virility, the very manliness understood as necessary to save by repopulating France, was seen as lacking. ${ }^{21}$ It would not be enough to blame the male population. The

\footnotetext{
${ }^{18}$ Robert A. Nye, Masculinity and Male Codes of Honor in Modern France. (Berkeley: University of California Press, 1998). 10.

${ }^{19}$ See Anthony Fletcher, “'Sticking it Out': Fear and Shell Shock," in Life, Death, and Growing Up on the Western Front (New Haven: Yale University Press, 2013).

${ }^{20}$ See Paul Fussell, The Great War and Modern Memory. (New York: Sterling Publishing Company, 1975), or Siân Reynolds, France Between the Wars: Gender and Politics. (New York: Routledge, 1996).

${ }^{21}$ See Nye, Masculinity and Male Codes, 1993.
} 
female population, working to keep France running, found themselves blamed for the loss of national virility and the birthrate: fashion choices as well as working were both considered to have consequences for natality. ${ }^{22}$ While their national service was necessary, French women suffered for it. Critics and authors of the period considered women at fault for emasculating French men with fashion changes, workforce adjustments as well failing to produce children. ${ }^{23}$ While being asked to support the nation with their work, they were accused of neglecting not only their children but their national duty as wives.

A gender analysis of this period provides a useful tool to examine French recovery after the war. The war propaganda of the period, produced and approved by the French government, worked to display the very things the French were scared of losing: traditional heterosexual relationships, the virile and brave male warrior, and the gender roles the war had disrupted. ${ }^{24}$ The imagery of the propaganda posters not only exposes the fears of the French government during WWI, but also provides for a closer inspection of the lens through which the government viewed wartime society. These governmentapproved optics push the myths of the brave warrior soldier and the demure mother/wife. Careful consideration of both the approved war propaganda images and war novels written by both civilians and soldiers, when juxtaposed, allows for a deeper analysis of the debates they created.

${ }^{22}$ Roberts, Civilization Without Sexes, 1994.

${ }^{23}$ See Roberts, Civilization Without Sexes, 1994, and Joan Tumblety, Remaking the Male Body: Masculinity and the Uses of Physical Culture in Interwar and Vichy France (New York: Oxford University Press, 2012).

${ }^{24}$ See Fussell, The Great War, 1975, Reynolds, France Between the Wars, 1996, or Roberts, Civilization Without Sexes, 1994, for more information. 


\section{Methodology}

My methodology is based on R. W. Connell and James W. Messerschmidt's "geography of masculinities." 25 This is a model that maps out the interplay of dominant and non-dominant masculine power structures at local, regional, and global levels. Viewing gender as a spectrum — femininity at one end and masculinity at the otherallows for fluidity and overlapping of gendered behaviors. The spectrum of gendered behavior enables a description of differentiated practices of masculinity and femininity removed from biological sex and thus no longer relegated to the practices and behaviors of specific groups. ${ }^{26}$ In addition, a gender spectrum facilitates a non-hierarchical approach to discussing, analyzing, and understanding gendered practices and behaviors that are also non-cisgendered, or biologically independent. I chose to use the gender spectrum for its ability to address multiple gender performances. However, the spectrum does not address the power dynamic encountered by those practicing normative and nonnormative masculinity and femininity throughout history, including the interwar period in both the propaganda and the novels I reviewed.

Because of the dynamic nature of gendered behaviors, practices, and cultural traditions, Connell and Messerschmidt's model of gendered geography and hierarchical power structures at local, regional, and global levels is pertinent when describing and interpreting gendered practices and behaviors expected of the French population in visual propaganda and the war novel. I supplement Connell and Messerschmidt's model of hierarchical masculine behaviors to accommodate femininity, from non-normative to pre-

\footnotetext{
${ }^{25}$ R. W. Connell and James W. Messerschmidt, "Hegemonic Masculinity," Gender \& Society 19, no. 6 (2005): 829-59, https://doi.org/10.1177/0891243205278639

${ }^{26}$ Ibid, 829-59.
} 
WWI traditional feminine behaviors, keeping in mind that in this altered model feminine performance would reside in a lower hierarchical position than some of the lowest levels of masculine performance in their model.

In arguing that the wartime and interwar novels present reality as it was lived, criticized, and idealized by soldiers and civilian authors, I examine the performances and standards of masculinity, femininity, and alterity in Celine's Voyage au bout de la nuit, Colette's Chéri and La Fin de Chéri, and, to a lesser extent, Gide's L'Immoraliste, Henri Barbusse's Le feu, and Victor Margueritte's La Garçonne. I argue that the portrayals of gendered behavior in my selected novels represent "the other" that was not present in the wartime propaganda poster. Considered injured, "the other" did not appear in wartime propaganda posters, which suppressed any gendered behavior that did not conform to nor meet the propagandized standards of masculinity and heteronormativity. In order to discuss the standards by which masculinity and femininity were performed, I rely on Judith Butler and Jack Halberstam. Following Judith Butler's theory on gender performance, specific sets of behaviors that are culturally significant and dependent render a sexed human masculine or feminine. Masculine standards are understandable as culturally informed instructions for performing or being. For example, the reader of L'Immoraliste can speculate that the protagonist Michel's struggles to perform masculinity began at a young age as he was assigned and instructed in masculine behaviors; his biology alone was not sufficient to "be a man.” Butler's work on performativity asserts that gender is not biological but a culturally informed performance. ${ }^{27}$

\footnotetext{
${ }^{27}$ Judith Butler, Gender Trouble: Feminism and the Subversion of Identity, 1st ed. (New York: Routledge Classics, 2006).
} 
I also refer to Jack Halberstam's work on masculinity and his analysis of the ways masculine performance is differentiated from feminine performance. The importance of masculine differentiation from the feminine is that masculinity is viewed as "natural" and femininity as "artificial." 28 Thus, it is this artifice that must be avoided to maintain a masculine performance, in other words, a self-denying or un-performance.

\section{Altered Standards}

Cultural standards of gendered behavior, as illustrated in the propaganda poster, were not new. The emphasis on standardized masculinity already weighed on French men. The foreign occupation and the peace treaty requiring France to pay massive reparations following the Franco-Prussian War was emasculating, and the subsequent reviving of the Conseil de Révision, the government-administered annual military service ascertainment, was an attempt to codify and verify the physical health of every French man for military service. These standards, which are represented by uniforms, fearlessness, vigilance, women-as-wives, and rifles, are recurring in war propaganda imagery and the interwar novel. Very likely influenced by these standards, the authors I examine wrote novels that propose more truthful narratives that contradict or even combat official state and military propaganda. I submit that these standards of masculine dominance, as illustrated in war propaganda and forced onto the French public, caused so much discomfort for Céline, Colette, and Gide, that such imagery and its import is not only evident in the interwar novel but is the unnamed antagonist.

\footnotetext{
${ }^{28}$ Jack Halberstam, Female Masculinity (Durham: Duke University Press, 1998), 240.
} 
In these novels, multiple characters of differing biological genders and nonstandard gender practices find themselves with one uniting factor: a desire for belonging and acceptance. Some characters, such as Bardamu in Voyage au bout de la nuit, search for their place by traveling through various cultures and continents while rejecting all conformity. Others, such as Charlotte in Chéri and La Fin de Chéri, adapt their dress and comportment to reflect their true selves. Finally, Edmée and Chéri maintain their dress and adapt their comportment and gendered behaviors to reflect their true selves by not fully conforming to culturally held standards of masculinity or femininity. For each of these characters, their war experience is a catalyst, compelling them to find means for living their non-normative genders within a world of narrowly defined and policed gendered behaviors.

In different ways, Collette's Charlotte and Edmée both adapted their true selves to their gender performances. Charlotte responds to wartime stresses by discarding her corset, dressing in fatigues and pants, and cropping her red hair, all of which would have scandalized traditional French society. These acts seem to have liberated her to be herself and not a prescribed version of matronhood. As Hollis wrote,

Irrespective of a corset's style and manufacture, removing one's stays had long been, iconographically, a symbol of female dishonor, of taking leave of social decencies. ...It denotes the sexual impetuosity of the woman and hence her hypersexuality or deviance..$^{29}$

For Charlotte, a former dancer and courtesan, removing her stays in late middle age is neither a nod to her deviance nor recognition of her dishonor. Instead, she removes her

\footnotetext{
${ }^{29}$ Clayson, Painted Love, 2003, 90.
} 
corset and alters her dress to her personal taste, finally realizing the fiction of moralizing fashion. The war, by way of altering the gendered work and social landscapes of France, thus catalyzed changes in dress, gendered behaviors, grooming, and personal agency.

\section{The Propaganda Poster}

The earliest WWI propaganda images, dating back to 1914, featured scenes of young men in uniform near what are ostensibly the frontline trenches. These scenes rarely include blood, enemies, fighting, or an indication of the real state of soldiers. ${ }^{30}$ Instead, the scenes in the trenches appear almost bucolic. For example, in Figure 5, the spectator imagines that the young soldier engages happily in French Christmas traditions, placing his shoes out for Father Christmas to fill with treats. The one-time Christmas armistice, the Trêve de Noël [Christmas Armistice; translation mine] of 1914, is not apparent in this image; this suggests that the unofficial truce was likely publicized, and the artist used le trêve to present "a civilized" and sanitized view of the war. The text beneath includes the soldier's wish for just one packet of tobacco. The young soldier is a vision, wellgroomed, bright-faced, good posture, and well-equipped with a soldier's gear, complete with a white scarf to keep him warm. His well-fitting uniform is neither in tatters nor dirty despite the earthen trench setting. The sky above is clear and the surrounding trench—where he appears to be reclining comfortably while standing up —is easily mistaken for a peaceful field covered with bales of straw. ${ }^{31}$ There is a striking similarity to Van Gogh's paintings of peasants reclining on hay bales. Further, Figure 5 shows no

\footnotetext{
${ }^{30}$ See Figure 5.

${ }^{31}$ See Figures 6 and 7.
} 
evidence of battle, fear, or death. The only indications that this is not a peaceful, bucolic scene are the soldier's uniform and rifle.

In contrast, historians and inter-war novelists present a dire portrayal of the WWI battlefront. ${ }^{32}$ Insufficient uniforms, rations, arms, men, and the deadly results of technological progress were the norms. The trench was a dangerous, dirty maze riddled with barbed wire, fear, death, and uncertainty, as evidenced by contemporary photography. ${ }^{33}$ The accounts of WWI soldiers and historians conform to those of writers Barbusse and Céline, in Le feu and Voyage au bout de la nuit, respectively. Both authors were active-duty soldiers in WWI and had their respective works criticized due to the depictions of chaotic battles, soldier conditions, and brutal violence. From all accounts, including those of Céline and Barbusse, the area dubbed No Man's Land earned that name because there were no men left. Soldiers were dead and villages abandoned. Men lost their lives, limbs, and hope in this place that signified the end of the world, with nothing to offer but absence, loss, and violence. Figuratively, this was an area devoid of humanity.

Barbusse used his own battlefield experience and that of his fellow combatants to expose the dehumanizing effects of war. To fully convey the impact of war, he leaves multiple characters nameless, brutalized by the war as well as their anonymity. Of the named characters in the squad, many slowly fall from focus or in battle as the novel progresses. Of the characters who do live, the reader often does not learn their stories or where they go after the war. A reader might wonder why Barbusse left these soldiers,

\footnotetext{
${ }^{32}$ See Fussell, The Great War, 1975, and Jay Winter, Sites of Memory, Sites of Mourning: The Great War in European Cultural History (Cambridge: Cambridge University Press, 1998), for more information. ${ }^{33}$ See Figures 8 and 9.
} 
who interact with his main character, without full identities. I suggest the author was elaborating on the symbolism of the characters' profession and location: No Man's Land. Men who go there often do not return, and if they do, they come home afflicted or mangled. Damaged physically and mentally, as Barbusse shows, they are no longer culturally considered "men" in WWI and Interwar France. Further, as long as the men remain anonymous, their existence is in doubt. Obliterated by the battle and again by a culture that could not reconcile the reality of actual men with traditional ideas of French masculinity, they are denied existence.

The spaces and soldiers in propaganda posters evolved over the course of the war, an evolution also represented in the novels of Barbusse, Colette, and Celine. The rosycheeked young soldier in the peaceful 1914 Christmastime image (Figure 5) is replaced just three years later by a mature man standing guard (Figure 10), a more realistic, less bucolic character. Although both scenes have many common elements, they, too, have transformed considerably. The trench is now recognizably earthen and clearly on the battlefront. Although the soldier appears clean, his uniform is no longer pressed and fitted; rather, it appears well lived in. The soldier is older but not a full departure from the pink-cheeked image from three years prior. The locale is the same; the circumstances are the same; the difference is that now the war is wearing on the public.

The image of an older man who seems battle-ready indicates two things. First, the experienced individual responds to and soothes the broader public fear that the Frenchman was somehow ill-prepared for warfare. Second, the aging of the soldier acknowledges the malaise in the public sphere created by the death toll of the war. The 
lies perpetuated by Figure 5 are no longer sustainable. Figure 10 does not tell the full truth, nor does it indicate battle. Rather, it implies battle readiness and defense.

A later image from 1917 changes the narrative once again. The first shift from the soldier standing vigil in the trench appears in Figure 11. This image is still not a complete departure from Figures 5 or 10, but there are some distinct changes. Although the older soldier in Figure 11 resembles that of Figure 10, he displays intense alertness with his gaze fixed upon the horizon, or perhaps the enemy. He is still shown in the trench and still seems fairly clean; however, for the first time in this series, his uniform shows visible signs of wear. There is also a significant change in physical stance. Rather than leaning against earthen walls, the soldier is depicted eagerly heading out of the trench. His rifle is in hand, and he seems ready to leap up from the protective earthen ditch. Taken as a whole, the image belies fear while acknowledging conflict. Figure 5 did not present a battlefield or a need to stand watch. In contrast, the later image concedes that French men are afraid, countering that notion with the fearless soldier peering across the battlefield, ready for action. This was a necessary transition, as the propaganda—read: the state - began to adjust their imagery to reflect some truth rather than the complete fabrication of Figure 5. The earlier image was sold to the war-wary/-weary French public after the Franco-Prussian near loss. Showing an older man in Figure 10 is also conceding that there are no longer any young men or conscripted civilians left. Older men were now eligible due to this desperation. Last, the state is admitting that these men are at war, in battlefields. 
Gendered Practice and War

For centuries, women have labored under the dichotomy of womanhood.

Culturally, socially, and religiously, women face a double standard that is paradoxically mutually exclusive. The goddess/whore dichotomy is embodied in social politics and the advertising poster of the pre- and post-WWI period, with presentations of the femme du foyer and the registered prostitute (goddess/whore). This stereotype applies to the multitudes of women in the workforce, as well. Clayson noted, "Paid employment of any sort...was out-of-bounds for the respectable bourgeoise" ${ }^{" 34}$ It is a cruel contradiction that fulfilling war needs meant employing women to take the place of men while these same women labored under this false dichotomy. Female nurses, doctors, and volunteers who wanted to assist in the war effort were not exempt, instead prevented by law from being nurses unless they were nuns. ${ }^{35}$ Women who served labored without healthcare, uniforms, rank, quarters, or rations, and often without pay. Field Marshal Douglas Haig of the British Army explained that women could not participate in any roles the military desperately needed filled due to the "danger from the soldier," thus granting only positions as maids who could only work when men were not present. ${ }^{36}$

The notions of masculinity and femininity were the primary battleground in a war for the ideals of interwar France. There was a perception of the sexes as both culturally and socially complementary in the interwar period; thus, discussing one without the other would produce an incomplete argument. To engage in the topic of masculine practice in interwar France, I begin with its companion, femininity. I will now guide my larger

\footnotetext{
${ }^{34}$ Clayson, Painted Love, 114

${ }^{35}$ Louise Elliott.Dalby, The Great War and Women's Liberation (Saratoga Springs: Skidmore College Faculty Research Lecture, 1970), 6.

${ }^{36}$ Ibid, 20.
} 
discussion of masculinity in interwar France by discussing the social discourse of femininity.

With WWI came unprecedented changes in demographics, economics, society, and culture. Women taking what were, prior to the war, men's places in the workforce assisted in the accusation of women for the feminization and degradation of men. ${ }^{37}$ As men left to fight and returned maimed or traumatized, French society looked to women to compensate. France lost more men than any other country in WWI $\left(1.3\right.$ million $\left.^{38}\right)$. This high mortality rate, coupled with low birth rates and the return of many soldiers psychologically and physically scarred $\left(1.1\right.$ million $\left.^{39}\right)$, was not only an affront to France's traditional patriarchal society, but a sign that the traditional patriarchal society faced extinction, a dangerous impediment to rebuilding the nation. French society struggled to reconcile the maimed war hero with the virile French man necessary for the continued defense and rebuilding that the nation would require. The vast numbers of men severely wounded and lost showed that women's necessity in the workforce was a true national need, not a premise constructed by the burgeoning feminist movement. ${ }^{40}$

To assist in the war effort, French women took on jobs and responsibilities traditionally reserved for men. This wartime role reversal allowed women to experience life in the place of men: at the center. The presumption that women only needed to hold these positions while the men were away proved to be in error. When men returned from the war, women not only wanted to work but needed to, and continued to do so while

\footnotetext{
${ }^{37}$ Roberts, Civilization Without Sexes, 1994, 73.

${ }^{38}$ Leonard Smith. France and the Great War 1914-1918, (Cambridge: Cambridge University Press, 2003), 69.

${ }^{39}$ Ibid, 69.

${ }^{40}$ Higonnet, Behind the Lines, 2.
} 
keeping a tenuous hold on their newfound liberties and independence. For many French women, the war was their first opportunity to work outside the home, earn a meaningful wage, manage their own finances, and ultimately develop a sense of agency.

Colette provides an example of this phenomenon with Edmée, wife of the male protagonist, Chéri, in La Fin de Chéri. Edmée appears marginalized and powerless prior to Chéri's departure for the war. Upon his return, however, she is a powerful force. From her nursing work, managing household finances, and giving Chéri no pity, she has blossomed in response to the burden demanded by the war. In a telling thought, Chéri describes how his relationship with Edmée has altered since his return from the war: "Pas d'erreur, songea-t-il. Le boudoir s'appelle à présent cabinet de travail." ${ }^{41}$ Related to more than just their intimate relationship, "the amorous" has become "the disinterested." The cabinet de travail to which Chéri refers is where Edmée spends hours checking reports, numbers, and bills, signing checks, and taking care of finances. To be fair, Edmée spends the war effort childless and with means. She takes over the household finances, managing Chéri’s investments while nursing wounded soldiers. Although these actions are primarily about survival, the lack of "male supervision" allowed her to use and develop new skills while discovering herself, free of Chéri's influence and authority.

Although the women of France faced new responsibilities due to wartime needs, these changes were not without strife. Long before WWI began, the Napoleonic Code gave women no rights to their children, not even legal guardianship in wartime. The advent of the war prompted women to address the Code. They were successful in gaining temporary guardianship status, if only during wartime. ${ }^{42}$ Nonetheless, women's legal

\footnotetext{
${ }^{41}$ Sidonie-Gabriell Colette, La Fin De Chéri French ed. (Paris: Flammarion, 1993), 4.

${ }^{42}$ Dalby, The Great War and Women's Liberation, 6.
} 
status changed very little, and the few provisions made would expire at the end of the war. Women with special training or more independence sought to offer direct assistance during the war. Women were eager to aid the war effort, a few as doctors, the majority as nurses and ambulance drivers. However, French society prevented many women from even volunteering to help the war efforts. Therefore, as men were sent off to serve, women snuck into battle zones in France to offer their assistance. ${ }^{43}$

Despite achieving eventual acceptance to provide services to the military, women did not receive consideration as service members. They were denied uniforms, rank, rations, and medical care. ${ }^{44}$ In a direct contradiction of the British War Office's own policy, the Head of the Office, Lord Derby, stated, "The employment of women in the Army has to come whether we like it or not, there must be no waste in the employment of women; every woman must be employed so as to replace a man." ${ }^{25}$ This statement seems to have been nothing more than the military posturing, as the above examples indicate. In contrast, the civilian world employed women in every possible role in France and Great Britain in the wake of having nearly all available men drafted into service. In fact, as Dalby writes, "men had to be officially dragged to war." 46

Higonnet asserts that "social differences between men and women are produced by systems of gender that construct and differentiate male and female activities and identities in accord with, but not actually determined by, biological sex." ${ }^{\prime 47}$ These same systems proved to be a myth in wartime, as shown in the civilian sector; however, in the

\footnotetext{
${ }^{43}$ Dalby, The Great War and Women's Liberation,., 9.

${ }^{44}$ Higonnet, Behind the Lines, 2.

${ }^{45}$ Dalby, The Great War, 18.

${ }^{46}$ Ibid, 18.

${ }^{47}$ Higonnet, Behind the Lines, 2.
} 
military, the systems were apparent on a smaller scale. The few women employed by the military were seen as a burden to the war effort, not a benefit. The civilian sector provided evidence to the contrary and showed the advantages of employing women in men's positions. Although the military could demand and force men to go to war, it could not be persuaded, forced, or coerced to allow women to cook, staff stores, sort mail, or be an official part of the war effort. To successfully manage wartime operations, the civilian sector suspended the myth of masculine and feminine identity systems, while the ideological functioning of the military hinged on the maintenance of the same myth. The civilian sector (mostly) accomplished the employment of women in men's jobs with few exceptions and little fuss, whereas the military, desperate for help, refused to employ women.

During the period under question, reproduction is clearly considered to be the burden of the man. As understood at the time, the "general physiological vigor of the father was usually regarded as the decisive factor in cases of infertility or stillbirth." 48 The era's pseudoscience indicated that the character of the man in question affected the gender of his offspring. ${ }^{49}$ In his book Patriotisme et paternité (1913), Fernand Boveret, the leader of the natalist movement between the wars, stated that "depopulation was the dishonor of the French," with the onus of reclaiming France's honor resting with the men. ${ }^{50}$ The honor of the soldier is not only tied to his bravery facing the enemy but also to his ability to reproduce: No reproduction meant no honor; no honor meant no virile

\footnotetext{
${ }^{48}$ Nye, Masculinity and Male Codes, 86.

${ }^{49}$ Ibid, 85-86.

${ }^{50} \mathrm{Ibid}, 96$.
} 
French men. The next step in this prevailing logic was that there would be no more France.

The needs of the war saw women taking men's jobs as a matter of necessity. French women were bringing home a wage and tasting economic independence for the first time. The functional "emancipation" of the French woman that had occurred as a stopgap during and after the wars, although ostensibly helping the nation and the war effort, led to suspicions that the working, independent woman engaged in acts of prostitution and, worse, had become infertile.

\section{Women and WWI}

Following WWI, changes in economics, fashion, grooming, and comportment on the home front marked a distinct transformation of the world for which the French man left to fight. Femininity was no longer known by its trappings and enforced by society, and women were no longer so easily cloistered and controlled. In addition to expanded financial responsibilities, women began to cut their hair, wear more modern fashions that eschewed the corset, and even take on other traditionally male habits, such as smoking, drinking, and enjoying their earned income. ${ }^{51}$ Ultimately, the same changes that drew women into the center facilitated the shift of traditional French masculinity to the margin.

Fashion took heavy blame for the most commonly "perceived changes in gender relations associated with the First World War-namely, the blurring of gender boundaries" $" 52$ The increased work lives of French women required simpler, more comfortable clothing. The corset and multiple layers that characterized pre-war fashion

\footnotetext{
${ }^{51}$ Roberts, "Samson and Delilah Revisited," 657-84.

${ }^{52}$ Roberts, Civilization Without Sexes, 73.
} 
were no longer practical, let alone cost-effective. Women's hairstyles had begun to shorten before the corset became optional, marking the loss of one more cultural signifier of femininity. The advent of la garçonne represented the most extreme example of modern fashion and lifestyle choices for women.

Within popular fashion and the style of la garçonne, the emphasis was no longer on any one feature of a woman's form; rather the sought-after shape diminished rather than called attention to breasts, hips, or waists. The garçonne, not unlike her more traditional peers, worked, smoked, and drank alcohol, yet her more masculine taste in dress and comportment set her apart from her contemporaries. ${ }^{53}$ The shorter, square dresses and the earlier advent of bloomers and athletic length skirts left pre-war ideas of the culturally desirable feminine form behind. This hairless, hipless, waistless, breastless "creature" fueled a myth of the disappearance of "woman," inspiring Pierre Drieu La Rochelle's statement, “Cette civilisation n'a plus de vêtements...plus de sexes." ${ }^{54}$ This myth finds a detailed representation in Victor Margeuritte's novel La garçonne (1922), considered so scandalous that it cost the author his Légion d'honneur. Cultural fear of this new "creature" inspired Margeuritte and other authors to ponder the effects such sartorial changes could have on all aspects of France's future.

Eh bien! Cette garçonne-là fera comme le garçon. Elle ira un peu plus à l'école ...La natalité baisse. Et pour cause! On ne verra bientôt plus, pour avoir enfants quand elles n'en voudront pas, que les idiotes. Et les séducteurs en deviendront du coup moins imprévoyants, et moins mufles. ${ }^{55}$

\footnotetext{
53 See Figure 14.

${ }^{54}$ Roberts, Civilization Without Sexes, 3.

${ }^{55}$ Victor Margueritte, La Garçonne (Paris: Flammarion, 1922), 66.
} 
Margeuritte, through his character Georges Blanchet, asserts that differences in the genders once held to be simultaneously compatible and disparate would disappear with male/female instead coalescing and becoming indistinguishable. Margeuritte predicts that as la garçonne became more like a boy, the birth rate would drop, and those men who might have wanted to seduce will wise up, becoming less careless and brutish to these new boy-like women. Worries over the falling birth rate were legitimate and women who fell outside of appropriate gender performances (e.g., la garçonne) took the blame.

The protagonist's aunt (tante Sylvestre), is shocked by the proposition of eliminating male and female sex role distinctions and abandoning maternity. She shrieks, “Mais c'est la fin du monde que vous annoncez là!” Monique, the protagonist, then announces the logic of equality behind the changes, saying, "Non, madame. La fin d'un certain monde, seulement. La fin...de l'hypocrisie et des préjugés." ${ }^{\circ 6}$ La garçonne, from Margeuritte's point of view, is a being that brings balance to the unjust hierarchies of male and female sex roles in traditional French society.

Margueritte is an example of an author who gives evidence for Higonnet's argument that "male and female authors challenged prevailing myths about their sex." 57 Margeuritte, Colette, and Céline all took part in these challenges to varying degrees. At first, Monique from La garçonne is scandalized by the idea of taking on male-gendered behaviors. When not afforded basic respect and fidelity from her betrothed, however, she loses faith and seeks to address the injustice by enacting revenge with a sexual tryst, as her fiancé had done. His response to her behavior, based on the assumption of a double

\footnotetext{
${ }^{56}$ Margueritte, La Garçonne, 66.

${ }^{57}$ Higonnet, Behind the Lines, 13.
} 
standard for the sexes, convinces her that more drastic changes are needed, and she begins to adopt the gender performance of la garçonne. Céline delivers a character in Bardamu who works toward rejecting conformity. Less interested in equality and seemingly bent on the destruction of all such concepts, Bardamu resists by flamboyantly rejecting conformity in any way he can, from rejecting a healthy relationship to challenging standards of traditional French masculinity. Colette's characters Edmée, Charlotte, and Léa, adjust their gendered behaviors, from demeanor, dress, and hairstyle to acts and activities considered masculine.

Colette demonstrates with the characters Chéri and Edmée how the trauma inflicted by the war experience on individual gender performances also granted a sense of freedom and independence to women, even if they did not adopt the garçonne identity. Colette fictionalizes the phenomenon described by Roberts: "At the end of the war they [women] refused to give up their lives of independence and become simple housewives once again.. ${ }^{58}$ Men returned seeking an idyllic, and perhaps hyper-idealized, vision of their former lives: "The man demanded his old position, but the woman refused to bow her head any longer, and instead played the part of rival. ${ }^{" 59}$ Colette demonstrates this dynamic and the feelings of the soldier returning from the war in her depiction of Chéri, who mourns his lost boudoir and finds that Edmée no longer needs him.

As Colette and other writers seek to show, women upgraded their roles by incorporating traditionally male work and behaviors into their gendered practices, rising to higher positions on the social and cultural scale, on par with the masculine position However, Mary Higgonnet reminds that these changes did not fundamentally alter

\footnotetext{
${ }^{58}$ Roberts, Civilization Without Sexes, 139.

${ }^{59}$ Ibid, 139.
} 
women's subordinate and dependent relationship to men. In the family, factory, schools, hospitals and on the street, men were still the masters. ${ }^{{ }^{60}}$ While this is a true statement, as my readings of Colette, Céline and Margueritte seek to show, Higgonet perhaps it oversimplifies a period in which numerous women made strides in gaining their independence and claiming some agency in their own lives.

It is impossible not to recognize that the binary system of gender that France knew as it embarked on WWI was temporarily under siege during and following wartime. As historians argue and novelists suggest, reestablishing pre-war traditions and a return to "normal" proved impossible, even without the advent of the most liberated woman of the era, la garçonne. The France that existed when the war began would not exist again, leading to calls for a great cultural accounting. Authors such as Henri Spont argued, "The social order is in such a profound state of upheaval that when one considers the future, a comprehensive revision seems imperative, "At present, everything has been called into question." ${ }^{61}$ Thus, with "everything...called into question," I now turn to a discussion of how officials, writers, and social scientists of the period sought to address these questions.

\section{Masculine Practice, the Conseil de Revision, and Physical Culture}

Since masculinity became equated with "France," Interwar society feared not only future conflict with enemies, such as Germany, but profound social collapse and degeneration. Without exemplars of a virile, healthy, traditional French masculinity, there could be no France, according to the era's ideologies of nation and gender. Before WWI,

\footnotetext{
${ }^{60}$ Higonnet, Behind the Lines, 57.

${ }^{61}$ Roberts, Civilization Without Sexes, 150.
} 
the success of rebuilding the French nation was the sole responsibility of French men due to the nation's defeat in the Franco-Prussian War and the subsequent Dreyfus Affair. ${ }^{62}$ In this earlier period, as well as during WWI, French citizenship was synonymous with the male sex, both legally and culturally. Formerly undefeated, this strike was not just to the French military but to all of French masculinity—hence, to the entire nation.

Prior to the Franco-Prussian war, masculinity had been determined by sex. Being of the male sex was sufficient to engender any man with virility and privilege. However, after the Franco-Prussian tragedy, the French man became subject to a twice-yearly government-administered physical, the "Conseil de revision" [Review Board], discussed earlier. Not only under pressure to rebuild, defend, and repopulate his nation, the French man found his physical body under scrutiny from the highest levels of the government and military, which would decide and declare his virility, masculinity, and worth as a citizen. Just as femininity underwent a comprehensive revision, to use Spont's terminology, masculinity was subjected to revision in a very public forum.

Established in 1805, the Conseil de revision was a means to choose future members of the military; however, over the decades, it became a coming-of-age government-sanctioned rite of passage for all young French men from 19 to 20 years of age. No young man could begin his profession or marry until he had passed this test. A military doctor or surgeon, along with roughly 15 other officials, reviewed the list of candidates for military service who underwent examinations of their intellectual and

\footnotetext{
${ }^{62}$ Subsequent to the Franco-Prussian War Captain Dreyfus, an officer in the French military and an Alsatian Jew, was charged with espionage, aiding the enemy in such a close conflict. The paranoia concerning the near loss and desire for a scapegoat polarized the nation. Rather than admit that the military had been matched in battle for the first time, Cpt. Dreyfus was falsely accused to cover national insecurities and explain away the near loss. Cpt. Dreyfus was cleared after five years in exile.
} 
physical capacity. Despite the conseil taking place in private at the "Mairie" [Town Hall/Mayor's Office], older local women would often insert themselves in the examination room. Referring back to Figure 19 a matronly woman, presumably a village matriarch, is seen pushing her way in at the door, this was not officially permitted after 1873 and yet was reported to be commonplace until the 1960 s. ${ }^{63}$ The "classe," as the young men would term themselves, saw their future determined by the results soon known by the whole town. Originally, being declared both "bon pour le service, bon pour les filles" [good for service, good for girls] was a family, if not a village, honor and a badge of virility and masculinity. The process was cause for celebration, with hats festooned with service cards and pictures taken.

In the early twentieth century, the number of men who did not meet the standards of the conseil was growing, and the rejection could ruin a young man. The original declaration of success was then divided from "bon pour le service, bon pour les filles" to either "bon pour le service" or "bon pour les filles.” The conseil and its results were so important on a social level that it became necessary to not only "pass" individuals fit for military service but also to "bless" those who did not pass lest they be branded a failure or not manly enough. The men began to receive a small ticket, declaring them either "bon pour le service" or "bon pour les filles." 64 This change in the measuring of success further indicates how deeply the standards of masculinity had saturated the nation ${ }_{2}$ affecting individual lives and notions of "France" itself, as after the Franco-Prussian war, the nation could no longer afford masculine failure. Instead of passing the men unfit for

\footnotetext{
${ }^{63}$ AMONT, Association Montaigne et Patrimoine, Le Conseil de Révision. Amontcev.free.fr/Le\%20conseil\%20de\%20revision_.htm\#_ftnref3 ${ }^{64}$ See Figures 17 and 18.
} 
military service in some other fashion, doctors declared them "bon pour les filles," a further indication of the heteronormative matrimony-centric culture. Prior to this label change, declaring men unfit had damaged their reputations, causing some men to be deemed unmarriageable. The conseil's decision made or destroyed a young man in the eyes of society. The conseil was proof of virility and masculinity; to fail was to no longer be a man.

The "Conseil de Revision" created a space in which, as Joan Tumbelty states, there was "a specific time and space where citizenship was judged through conformity to the physique of normative masculinity and health." ${ }^{65}$ Following the Franco-Prussian War it was enough to be physically male and meet the nineteenth-century requirements of intellect, restraint, and strong character. ${ }^{66}$ For example, Colette's character Chéri fit the nineteenth-century standards for masculinity, yet his gaunt face, dark-ringed eyes, and thin chest call to mind the young men illustrated in Figure 16, who are young men undergoing the physical examination of the conseil, representing exactly what the satirists illustrate as failure. Especially in the period leading up to WWI, tales of deficient physiques and high failure rates lent credibility to fears of the masculine demise. A preoccupation with the physical, from fashion to health to beauty, exposed a "fear of physical decline and its national implications." ${ }^{67}$ Degeneration thus became a cause célèbre of interwar France.

\footnotetext{
65 Tumblety, Remaking the Male Body, 10.

${ }^{66}$ Gail Bederman, Manliness and Civilization: A Cultural History of Gender and Race in the United States, 1880-1917 (Chicago: University of Chicago Press, 1996).

67 Ibid, 11.
} 


\section{Degeneration}

French society understood degeneration to have caused France's defeat in the Franco-Prussian War and near-defeat in WWI. According to Daniel Pick, "Degeneration involved at once a scenario of racial decline and an explanation of 'otherness,' securing the identity of...the scientist, (white) man, bourgeoisie against superstition, darkness, femininity, the masses." ${ }^{68}$ As shown in the Dreyfus affair, the idea of "Frenchness" became racialized, and being the "other" had an impact on one's inclusion as a citizen of the French nation. Cpt. Dreyfus' Jewish heritage separated him racially from the French citizenry, according to the era's concept of "Frenchness." The idea of a contaminated "race française" accompanied the nationalist paranoia and was fueled by the belief in eugenics held by many French physicians and politicians. ${ }^{69}$

Physical failings were often a means to identify "contaminating others" and to justify national fears and cultural paranoia. Interwar physical culturists looked to the past to trace the current traits and characteristics of a population. The study of inheritance in regard to what were likely acquired characteristics was considered scientific. The luxury and excesses of the Belle Epoque received blame for degrading the masculinity of later generations, with the then-present-day fatigue and neurasthenia then attributed to parentage. ${ }^{70}$ The perceived decadences of the prior century had presumably polluted the gene pool. Historians, such as Robert Nye, evinced that "fear about the demographic decline and racial degeneration powerfully influenced Third Republic politics and social

\footnotetext{
${ }^{68}$ Daniel Pick, Faces of Degeneration: A European Disorder, c.1848-c.1918 (Cambridge: Cambridge ${ }^{69}$ Ibid. University Press, 1993).

${ }^{70}$ Ibid.
} 
reform... and even stimulated the French eugenics movement." ${ }^{\text {71 }}$ Analogous to physical culture's ability to rehabilitate the body, as French physical culturists and doctors claimed, excesses of earlier generations could be excised from the genetic future of France in the same way, thus, extending an individual's perceived state of fitness to reflect the fitness of the country. ${ }^{72}$

The anxieties facing the French - the near defeat of WWI, women taking on men's roles outside the home, and the fear of not being able to rebuild the ranks of the French military (due to paranoia of future threat) — revealed how these insecurities were projected onto the male body. As France was formerly undefeated, the blow of the Franco-Prussian war was perceived as not only a loss of territory but as a crippling blow to French national identity and its foundation: masculinity. The male body in advertising, political cartoons, and public debate appeared as a physical manifestation of the weakened French state, embodied by its men, few of whom were healthy and old enough to serve the state in any capacity. Masculinity during this period was thus in profound crisis. Political cartoons and commentaries from the inter-war period and before WWI depict conscripts consistently below standards. In addition, the military added the previously referenced "bon pour les filles" category to the military review process to bolster social confidence in failed conscripts, ${ }^{73}$ allowing such men to still marry.

Typical of the Conseil de Revision political cartoon, Figure 16 (1842) indicates the national fear and paranoia over the male form. The young men are complete opposites from those depicted in Figure 15, published on the cover of La Voix du Peuple (a

\footnotetext{
${ }^{71}$ Sean Quinlan, The Great Nation in Decline: Sex, Modernity and Health Crises in Revolutionary France c.1750-1850, 1st ed. (New York: Routledge, 2016), 217.

${ }^{72}$ See Figure 20.

${ }^{73}$ See Figures 17 and 18.
} 
satirical/political magazine) in February of 1907, who are drawn with good posture, strong jawlines, and developed musculature. This political statement calls into question the Conseil and those who run it as well as their "victims." These young men resemble the standards of masculinity echoed in Figures 23, 24 and 25. It is worth noting that the officials in this image lurch for the healthy young man, grabbing and clawing at his virility in the name of France. While this is an opposite sentiment from Figures 16 and 19 (which depict the men under review as failing), it provides a perspective for the period that masculinity was perceived as under threat even by those who did not see masculinity itself as failing. The officials pictured in Figure 16 are not only healthy, but they show shock and surprise when measuring the young men: "It's a glorious spectacle to see noble French youth, full of enthusiasm, strength and elegance fight for the honor of serving our nation under Mars' flag!" [translation mine]. The sarcasm of the statement is hard to miss coupled with the twisted, malnourished, and physically lacking male forms present for the exam. A full nineteen years before WWI would begin, insecurity in the male body was already on display, as seen in Figure 19, which appeared in Le Rire on April 6, 1895. There are less-obvious defects in the men who appear in this image, yet the sarcasm persists: “At the Review Board: from the rich man to the mason's apprentice, to Apollo in the artist's drawing, all are forced to exhibit their anatomy and the nation chooses from the heap," [translation mine] —a "heap" of young men who are all soft, round, and knockkneed.

Defeat by degeneration had a very physical remedy, according to French physicians and theorists. Many professionals felt that a culture devoted to the body and the development of health and virility would cure France of her ills: the low birth rate, 
threats from aggressive nations, and uppity women. Thus, physical culture was not only a way to fix the broken French male, but was the path to being a good citizen. Exercise became an act of patriotism and nationalism, as one shed the burdens of past wars, lethargy, defeat, low birth rates, military shortages, and most importantly, gender trouble. The physical culture movement focused on the male body, then as the symbol of the nation's strength and health.

Political parties, schools, academics, and government programs were obsessed with the male form and with defining and pathologizing it. This is evident in political cartoons, propaganda, and publications. ${ }^{74}$ As discussed on pages 37 and 38, Figure 15 is an example of an anti-conseil de revision cartoon. The central female image, adorned with "Patrie," reaches out a long, deformed, and clawed hand to grab the young man. A military man holds the young man from the left while a round, older man-adorned "Capital" with a lock on his large belly_holds him from the right. The table in the background is an assembly of round men in uniforms who seem disinterested in the struggle before them. Importantly, this allegorical cartoon is one of the few political comics on the subject, for or against the conseil de revision, to feature healthy young men.

The young men in the foreground of Figure 15 look on in fear and anger as their classmates struggle against forces of "la patrie," "le capital," and "l'armée." The struggle is futile; their bodies and very identities are up for scrutiny at the hands of forces they cannot escape. This image thus represents what the authors that I focus on in this thesis illustrated in their novels: that young French men were vulnerable to highly

\footnotetext{
${ }^{74}$ See Figures 15, 16, and 19.
} 
politicized decisions about their masculinity based on subjective physical standards. The only way to succeed in life was to pass the conseil de revision - literally or symbolically - and play the part of the warrior-hero, as Chéri, Bardamu, and Michel all attempt to do. The novels in which they appear indeed represent an ideology and practice in which France sacrifices her young men to "l'armée" in the name of "la patrie."

\section{Chapter Outline}

This paper comprises the following chapters: Chapter One: André Gide and PreWWI Masculinity: L'Immoraliste, Chapter Two: Colette and her Muse of Masculinity; Chéri and La Fin de Chéri. Chéri, and Chapter Three: The Anti-Hero and the Rejection of Soldiering as Masculinity in Céline's Voyage au bout de la nuit. Each novel features a male protagonist impacted by standards of masculinity, both implicit and propagandized. The female characters of each work, to be certain, face similar standards. Throughout my argument, I will show the similarities and differences of the novels' masculine and feminine characters with propagandized forms of masculinity and femininity. These propagandized forms opposed the masculine and feminine performances by some of the novel's characters and attested to the veracity of other characters' performances. The analysis will demonstrate that in each work, the inability to comply with propagandized standards of masculinity was ruinous.

To begin, Chapter One is entitled André Gide and Pre-WWI Masculinity:

L'Immoraliste, in which I discuss tenets of pre-WWI masculinity: marriage, industry or land ownership, and reproduction. These same tenets, along with male biology, defined French citizenship in the late nineteenth century, the period André Gide chose for L'Immoraliste. Gide's protagonist, Michel, comes abruptly into adulthood, where the 
tenets of nineteenth-century masculinity assail him. I will discuss how Michel's attempts at conformity lead to illness symbolic of Michel's pursuit of late-nineteenth-century standards of masculinity, as his weak self is cause for a discussion of degeneration. An analysis of physical culture assists in understanding when Michel adjusts his behavior and performance to be authentic to himself and begins to heal. Although Michel finds his health, he still cannot compete with propagandized standards of the poilu, which now finds itself at the forefront due to national security fears. His decision to reject conformity has disastrous consequences, as he spends most of his fortune, sells his inherited properties, loses a child to miscarriage, and, later, his wife to illness. I argue that the cost of rejection was greater than Michel could bear; he finds himself a man without a country or culture, having rejected all that informed his masculinity and citizenship in French culture.

Chapter Two is entitled Colette and her Muse of Masculinity; Chéri and La Fin de Chéri. Chéri opens, not unlike L'Immoraliste, in the late-nineteenth century. The novel is replete with the expiring tropes of the Dandy and the "Fille de Joie"; as such, the decadence of the nineteenth century is on full, yet diminishing display. With the characters of Chéri, Léa and, to a lesser extent, Edmée and Charlotte, Colette presents an image of pre-WWI masculine and feminine behaviors that range from dandyism to female masculinity. I will discuss degeneration in relation to Chéri’s physique. Much like Gide's Michel, Chéri's masculine practice relies on the tenets of nineteenth-century masculinity and citizenship. His physical self counts for very little in his citizenship and authority, yet he does not suffer for his odd effeminate behaviors. Propagandized forms of masculinity do not align with Chéri's physical self or performance of masculinity. $\mathrm{He}$ 
has more in common with the Dandy than the Poilu, which Gide establishes in the text, with a boxing lesson and a comparison to WWI propagandized visions of masculinity. It is possible to examine Léa, as a traditional courtisane, much like Chéri: via the text and advertising posters of the period. The dialectics of feminine commodification are represented clearly in the text and reinforced in the advertising poster. I use John Berger's Ways of Seeing to assist in the reading of these images and for my comparative analysis. Chéri closes with Chéri telling Léa farewell, not accepting her age or the accompanying decay.

La Fin de Chéri opens post-WWI with Chéri, the petulant dandy of the previous novel, returning from the war as a hero. Seven years have passed since his farewell to Léa. The war experience leaves him hollow and searching for familiar elements from his former life, yet they have all vanished due to the war. These touchstones relied heavily on the gendered behavior of French women. Chéri seeks respite with his wife, Edmée, who has transformed into an independent, self-assured woman, no longer offering Chéri the pre-WWI subordinance that had defined their relationship. His mother, Charlotte, has moved her feminine practice close to that of the garçonne, or even female masculinity. Chéri faces what many WWI veterans did: an unexpected change in life at the home front that had its roots in the war itself.

The same impetus pushing Chéri to search for things "the way they used to be" also drove the women in his life to abandon, or more likely, adapt pragmatically from, the way things used to be. Missing these two points of reference, Chéri seeks out Léa, hoping she can provide the missing structure for his life. As Simone de Beauvoir explained in The Second Sex, masculinity seeks to define itself in relation to femininity. Chéri 
exemplifies this need to build identity in opposition to "the other": woman. Although this method may have aided Chéri in pre-WWI France, the post-war era does not offer such luxuries. Instead of finding women easily defined by domestic roles and other pre-WWI gendered standards, he encounters women who are steady and strengthened by their wartime experiences and hardships. This leads him to chase the past, seeking out Léa.

Chéri finds disappointment rather than the paragon of pre-WWI femininity that he imagined would endure, not unlike the ladies of the advertising poster. Colette emphasizes the change in the world around Chéri, yet not within him. The author thus places emphasis on his inability to change and his lack of utility in the post-war world, leading to my analysis that the pre-WWI masculinity no longer has a place. Propagandized wartime masculinity, the warrior or soldier, has overtaken pre-WWI masculinity.

Chapter Three is titled, The Anti-Hero and the Rejection of Soldiering as Masculinity in Céline's Voyage au bout de la nuit. I discuss Louis Ferdinand Céline's Voyage au bout de la nuit. Much like Colette's Chéri, Céline's Bardamu is a young man at the outset of WWI. Bardamu makes potential arguments against the state and the lot of the civilian/soldier in the grand scheme of warfare and government; however, he falls in line with pre-WWI masculinity, volunteering for the war effort after becoming caught up in the pomp and circumstance of a military parade. In this propaganda-fueled state of mind, he runs to join the frenzy and marches off with the parade. Unlike Gide's Michel, Bardamu finds himself drawn subconsciously to confront standards of French hegemonic masculinity. Yet, no sooner than he has joined does Céline use this and following events to demonstrate the futility of pre-WWI masculinity. 
Bardamu's show-off antics reveal a Sartrian critic of masculinity and heroism. This critique lays bare the need for le regard de l'autre, without which pre-WWI masculinity and the hero do not exist. With both of these things exposed as myth, Bardamu announces that he considers himself a lâche and that the world would be better if more people (read: men) were, as well. This is the opposite of mainstream pre-WWI French masculinity. The propagandized version of masculinity that Bardamu must pretend to confront has put him in danger and required that he kill for patriotism. Céline examines the character's absurdity once again when Bardamu tries to desert but is instead mistaken for a hero. Absurdity follows Bardamu around the globe as his trajectory takes him from France to Africa, then from Africa, in what he perceives as a slave ship, to America. The entire episode could be a hallucination, but it is symbolic for Céline of the plight of the working man. In America, Bardamu is no longer in a situation that is itself absurd; rather, he now employs the absurd in his decision to leave and return to France. The ensuing events further break Bardamu, leaving him unable to function in a post-war world where the tenets of pre-WWI masculinity no longer have a place. He is now inadequate and even useless, as the men on the ship during Bardamu's travel from Africa to America told him, "On doit avoir l'air utile." 75

\footnotetext{
${ }^{75}$ Louis-Ferdinand Céline, Voyage au bout de la nuit, French ed. (Paris: Assimil, 2000), 111. (One has to seem to be useful.)
} 


\section{ChAPTER ONE: ANDRÉ Gide AND PRE-WWI MASCULINITY: L'IMMORALISTE}

Literary portrayals of masculinity prior to WWI addressed the masculine condition and its environment. These works concentrated on the heteronormative standards that were applied to male citizens of pre-WWI France. Topics related to normative masculinity, such as coming of age, education, business, inheritance, the violation of social and cultural mores, and marriage, took precedence in the social lives of characters such as André Gide's Michel L'Immoraliste (1902).

Thoughtful contemplation of these topics in Gide's work thus can uncover many pre-WWI French standards as they were applied to boys as well as adult men. As L'Immoraliste shows, enforcement of these norms affected men directly and shaped their interactions with family, friends, romantic interests, and the world at large. L'Immoraliste represents these norms in terms of Michel's education, his taking on of his father's business and managing the families' assets, and, of course, marrying. These tenets of preWWI French masculinity operated to provide conduits of inheritance from father to son and enforced male dominance in the workplace and at home. Gide's novel shows, however, that for some, codes of masculine dominance proved difficult and incompatible with personal desires. The protagonist, Michel, is stymied by these codes and the behaviors they are expected to inculcate in young men. In Gide's handling, French cultural measures of masculinity of the pre-war era portent Michel's lifelong struggles. But it is Michel's grappling with these measures of masculinity that allows Gide to delineate the boundaries that defined masculinity and within which male subjects were to fit before the outbreak of WWI. 
L'Immoraliste is a novel whose genre, similar to Michel's selfhood, is not clear. The novel has a multi-genre disposition that fluctuates between a bildungsroman and a travel narrative and includes tropes from the nineteenth-century epistolary novel as well as modernist colonial orientalism, which equates the Western unconscious and desire with ethnic and class otherness and marginality. I suggest that the uncertainty in the genre does two things: One, it acts as an allegory for Michel's cloaking of his interior desires due to the misalignment between himself and traditional French masculinity, and two, it is symbolic of his conflicted self.

This uncertainty in genre signals Michel's lack of certainty as well the death of a beau idéal in his life. ${ }^{76}$ The relationship with his father is cut short by the latter's death (his mother has passed in his early teen years and has had seemingly little influence on his adult life). He admits that his few friendships have been presumptuous and selfserving: “J'aimais quelques amis...mais plutôt l'amitié qu'eux-mêmes; mon dévouement pour eux était grand, mais c'était besoin de noblesse." ${ }^{\prime 77}$ Michel is, in effect, an orphan and a loner; he is closed to others, and he admits to using relationships to his personal advantage rather than as a means of developing his own sense of self through those relationships. Michel suffers from a lack of public masculine subjectivity that he can identify with and subject himself to, and this is reflected in the novel's lack of a clear genre, which would otherwise serve to represent as linear and untroubled Michel's path. The vacillating genres in the novel reflect the uncertainty Michel displays in regard to his selfhood, symbolizing the circuitous path his life will take throughout the novel. Without

\footnotetext{
${ }^{76}$ beau idéal - 2. a model of excellence https://www.dictionary.com/browse/beau--ideal

${ }^{77}$ André Gide, L'Immoraliste, (Paris: Gallimard, 1972), 23. (I loved a few friends...but I preferred the friendship to the friends; my devotion to them was great, but it was in need of nobility...).
} 
a predetermined structure in his life, he vacillates between seeking his authentic self and conforming to traditional French masculine standards, yet another instance of uncertainty. His trajectory is not set or balanced upon a standard to which he can fully ascribe.

After the brief introduction of the frame narrative and epistolary twist, the novel behaves like a travel narrative, a bildungsroman and orientalist modernism. Like Michel, the novel does not know what or who it wants to be. Michel is not able to find or construct a model of masculinity that matches his sense of self, as he is at once conventional, bourgeois, academic, and homosexual, which in the novel is associated with existence on the margins and immorality. The multiple genres in the novel are figurative of Michel's search for a masculine model, his desire to find his authentic self, and his inability to live authentically. The novel reflects his inability to "fit in" by failing to adhere to a clear genre.

Thus, the novel's multiple and shifting genres reflect Michel's uncertainty about who he is and what he should do, where he should go. Michel demonstrates a hesitation to fully acknowledge and develop his authentic self as well as comply with traditional values of French Republican masculinity, and Gide renders his narrator explicitly oblivious, again emphasizing uncertainty. Albert Guerard describes L'Immoraliste's shifting genres as the "device of the obtuse or self-deluded narrator as the subject of the story he tells." 78 Michel is portrayed as unconscious in regard to his latent homosexuality and the norms of masculine performance; he is removed from them as well as from keeping track of his own vacillations. However, as Guerard states, employing the device in L'Immoraliste is successful, earning it a "proper place as one of the formal triumphs of

\footnotetext{
${ }^{78}$ Albert J. Guerard, André Gide (Cambridge: Harvard University Press, 1951), 99-118.
} 
the modern novel." ${ }^{\prime 79}$ L'Immoraliste's form indeed mirrors Michel's psychic wandering and search for agency, for the self-understanding that will permit him to be the confident teller of his own story.

The novel begins as a letter written by Michel's unnamed school friend to a certain "D.R. président." ${ }^{80}$ In the first paragraph of the novel, uncertainty takes center stage thematically and stylistically. At the end of Michel's story, the anonymous friend writes an account of the confession Michel has made to his friends following his urgent demand that they travel to meet him in North Africa. To clarify, Président du conseil refers to the Président du conseil des ministres—or, as known today, the Prime Minister of France. (Further, the unnamed letter writer refers to Mr. D.R. Président du Conseil as his brother.) The anonymous friend begins his account of Michel's story with his own feelings of uncertainty:

Tu l'avais demandé; je te l'avais promis; mais à l'instant de l'envoyer, j'hésite encore, et plus je le relis et plus il me paraît affreux. Ah! Que vas-tu pensé de notre ami? D'ailleurs qu'en pensé-je moi-même? ${ }^{81}$

This transition from the letter writer's words to Michel's is so seamless that the reader forgets that Michel was not the writer. In fact, it is another instance of uncertainty executed by Gide's successful use of the frame narrative. This transition further masks Michel's story and inserts a literary veil between the story and the audience. So, while the novel's genre is figurative of Michel's vain search for a model of masculinity and his

\footnotetext{
${ }^{79}$ Guerard, André Gide, 99-118.

${ }^{80}$ Gide, L'Immoraliste, 13.

${ }^{81} \mathrm{Ibid}, 12$. (You asked for it; I promised it to you; but at the moment of sending it, I still hesitate, and the more I reread it, the more it looks awful. Ah! What are you going to think of our friend? Besides, what do I think about it myself?)
} 
inability to adhere to a clear genre, the reader never truly reads Michel's words but his friend's, which can lead us to assume that Michel's ascribed "reticence" was never his. ${ }^{82}$ Michel sent a request for his friends to join him in North Africa with the intention of telling them his story, not hiding his story.

Another instance of uncertainty executed by Gide's frame story is that this inability to find or identify a model of masculinity (he is at once conventional, bourgeois, a member of a cloistered elite, an academic scholar, and a homosexual) appropriate to Michel's interior life is not only his limitation but also that of his listeners: These friends who attend his confession and then, in a sense, smuggle his story and transmit it to both the reader and the authoritative center of the Third Republic, the Prime Minister, hoping to find a conventional career for Michel back in France where he will remain cloaked. Reasons for his request and subsequent confession invite speculation. Knowing that his unnamed friends' brother is the Prime Minister of France, it would be fair to say that Michel has friends in high places. Was Michel seeking absolution in confessing? Perhaps he is vacillating back to conformity, seeking to return to France under the auspices of well-placed friends. The text does not illuminate these issues, and Michel does not entreat these things. It is his unnamed friend and letter writer who asks that his brother, the Prime Minister, find or create a challenging government position equal to Michel:

\footnotetext{
${ }^{82}$ Michael Lucey, Never Say I: Sexuality and the First Person in Colette, Gide, and Proust (Durham: Duke University Press, 2006), 84. "I am pleased that he only barley cracks the egg...I am pleased that he cannot fully shake off the frightful nets of atavism, of education, of habit. ...It is this reticence, Reticence! To which I am attached! If Michel freed himself he would cease to interest me. ...Michel must remain a slave if Gide is to continue to be of interest to us." Lucie Delarue-Mardrus.
} 
Saura-t-on inventer l'emploi de tant d'intelligence et de force-ou refuser à tout cela droit de cité? En quoi Michel peut-il servir l'État? J'avoue que je l'ignore...Il lui faut une occupation. ${ }^{83}$

The writer acts out of an abundance of care and concern for Michel as he fears that Michel could be exiled just as easily as given an invented occupation.

\section{Masculinity Prior to WWI}

Behaviors considered representative of masculinity in the period before WWI included being responsible for marrying, bravery, courage, not complaining ${ }^{84}$, avoiding effeminacy, grooming, gesturing appropriately a high work ethic, and even maintaining a balance between social politeness and warrior tendencies. ${ }^{85}$ Higonnet summarized masculinity as "hardness, courage, or willpower." ${ }^{86}$ The attributes listed discuss behaviors, both personal and cultural, that constitute masculine performance and differentiate it from femininity.

As the discussion suggests, the sexes participated in a highly regulated dichotomous lifestyle in the period leading up to WWI. The heteronormative climate of France levied constraints and expectations on both sexes. On a cultural and social level, the expectation and imposition of marriage affected men and women alike, as Gide's novel shows. With the institution of the Napoleonic Code in 1804, women lost rights to

\footnotetext{
${ }^{83}$ Gide, L'Immoraliste, 7. "Will be able to invent an employ for so much intelligence and strength or deny all of this rights to citizenship? In what manner ca Michel be of service to the State? I admit I do not know...He needs an occupation."

${ }^{84}$ Ibid, 75 .

${ }^{85}$ Lindsay Green-McManus, Performing Masculinity: Control, Manhood, and the Rhetoric of Effeminacy (Berkeley: University of Southern California Press, 2007), 72-75.

${ }^{86}$ Margaret Higonnet, "Authenticity and Art in Trauma Narratives of WWI," Modernism/Modernity, vol. 9, issue $1,2002,93$.
} 
inheritance, property, consent to marry, divorce, minor children, and work. ${ }^{87}$ A young woman was little more than property transferred from her father to the intended groom. The bride-to-be shared the same legal standing as a child. If she should have any wealth or possessions, her access and claim to it ended with marriage and her husband's began. As noted by Judith Surkis, "conjugal love" was necessary to bring an individual to a place of acceptable sociability. ${ }^{88}$ Further, the family unit became symbolic of French society.

Pre-WWI propaganda posters represent both overt and less obvious ways that heteronormativity was propagandized as the ideal state for men and women alike in the late nineteenth and early twentieth centuries, as seen and alluded to in Figures 23, 24, 25 , and 26. Figure 23 depicts a young woman in the foreground who makes direct eye contact with the viewer while seated in what seems to be a garden with pink roses. She is surrounded by relative peace and safety while the young man above her is not. The young soldier poses with his rifle in full uniform. Although his uniform seems intact and he appears well supplied, he stands in the foreground of the ruins of a large home or farmhouse. Further, the sky, as illustrated in the two vignettes, reveals a difference or dichotomy that cannot be overlooked. The young woman has what appear to be a few clouds in her otherwise clear sky; the young soldier has nothing but gray smoke. The dividing line between the two would-be lovers is foliage, ostensibly because the young woman is in a garden and the young man is at the battlefront. Closer inspection reveals that the "foliage" closest to the young man is not all plant life but barbed wire, ruins, and

\footnotetext{
${ }^{87}$ Adrienne Rogers, "Women and the Law," In French Women and the Age of Enlightenment, ed. Samia I. Spencer (Bloomington: Indiana University Press, 1984), 49-63.

${ }^{88}$ Judith Surkis, Sexing the Citizen: Morality and Masculinity in France, 1870-1920 (Ithaca: Cornell University Press, 2006).
} 
barriers. The caption for this scene is "Le Rêve," or The Dream. The audience should understand this as an admirable and desirable state for both men and women: He, the soldier in harm's way, and she waiting patiently, while observing traditional French femininity with her long hair and skirts.

Figure 25 presents another similar vision. The "Demande de Marraine" represents the young soldier who desires a young "godmother" to correspond with, provided she has "great stores of love" to share. ${ }^{89}$ The request, as in Figure 23, employs a young soldier's image but avoids battlefront imagery. However, the young woman in this request is less traditional, with her modern haircut, a bob, and a shorter skirt.

Figures 24 and 26 both present the soldier but from a different perspective. No longer is the soldier searching for a connection; now he is producing heirs, potentially future soldiers. The emphasis is clearly on supplying soldier's needs to protect the family, yet half are in the effaced image. In Figure 24, the imagery is oddly incomplete. We see the more mature poilu figure, as discussed in the introduction, home on leave, holding his young daughter aloft, while the rest of the image is merely penciled in. This juxtaposition renders the woman, so sought after in Figures 23 and 25, an afterthought. The poilu is, as the soldier in Figure 23, well dressed and clean. He appears healthy and concerned for his child. The woman in the background is nursing a small infant, young enough to be the product of a prior successful leave.

Figure 26 takes the family and soldiering propaganda to a new level. This image shows a rifle in the foreground draped with seven babies in carriers and one sitting atop the butt. The caption explains that the repeating rifle is good for repopulation. There is no

\footnotetext{
${ }^{89}$ Figure 25, “Demande de Marraine,” Request for a Godmother.
} 
more family in this image, just a small homestead in the background. The phallic presentation of the rifle and symbolic "bullets," or babies, are a particularly violent image of the family and reproduction. The soldier-father is now no more than the rifle and phallus. He is only important in these two aspects. The mother is no longer even a pencil sketch; she is nonexistent. The only reference left to the mother is the rose in the left lower corner. As the images (Figures 23, 24, 25, and 26) progress, the romantic relationship was reduced by and according to principles of republican citizenship. Marriage was the ideal state and reproduction, or the insurance of inheritance; production of future soldiers and citizens was the ultimate goal.

These highly symbolic images were more than reminders to invest in the war effort, provide moral support to troops, and extoll the virtues of a certain rifle. Standards of republican citizenship such as marriage, family, and civic duty are embedded in these images in such a way as to provide subconscious, and not-so-subconscious, reminders to the viewer. These coded messages were visual expressions of acceptable gender performance.

As Halat stated, if biology were enough to demonstrate manliness, "The call to masculinity would be unnecessary, as any biological man would have sufficient qualifications for the term." ${ }^{\prime 90}$ Such behaviors are, in short, external standards that correspond to outward performances based on no more than biological sex. Indeed, the WWI propaganda images, such as Figures 23 through 26, inform and reinforce acceptable performances for both male and female citizens. In images 23 through 26, the viewer

\footnotetext{
${ }^{90}$ Rebecca Halat, Un homme un vrai: Martial and Alternative Masculinities in French War Literature and Film (Minneapolis: University of Minnesota, 2014), 17.
} 
faces multiple gender-based performance prompts, ${ }^{91}$ but, finally, the conjugal relationship and family are of little consequence. The objective was, instead, children-future citizens - even as the image of the patriarch standing over his family unit symbolized the strength and stability of the Republic.

\section{Michel: A Bildung Project}

Michel's personal story starts in his adolescence, his academic formation, and life in books, studying antiquity and visiting ruins with his father. After losing his mother in his early adolescence, Michel is alone with his father. His knowledge of the world is limited to what he read of antiquity, as he has no interaction with the world apart from his father's library and academic colleagues, with further impact from his susceptible health:

J'étais d'une santé très délicate. Comment l'eussé-je su, ne l'ayant pas mise à l'épreuve? J'avais des rhumes de temps à autre, et les soignais négligemment. La vie trop calme que je menais m'affaiblissait et me préservait à la fois. ${ }^{92}$ With such tricky health, Michel was, no doubt, protected from the larger world and its values and impositions. This highly cerebral adolescence, as he describes, did not prepare him to live without his father acting as a buffer from the expectations of the outside world.

Michel is able to work in many languages, having learned Hebrew, Greek, Persian, and Arabic, as well as dead languages, such as Sanskrit and Latin, before the age

\footnotetext{
${ }^{91}$ First, appropriate relationships are heterosexual. Second, of the partners, the male is active while the female is passive. She waits patiently and loyally while he fights or works. Third, appropriate relationships produce children. Ultimately, the relationship is of little consequence and as the republican family unit develops, the objective was instead reproduction, creating future citizens.

${ }^{92}$ Gide, L'Immoraliste, 12. "I was in very delicate health. How would I have known having never have tested it? I had colds from time to time, and I treated them very negligently. The too calm life that I led had both weakened and preserved me."
} 
of 20 , yet he never speaks. His own story is told by an unnamed third person in a frame narrative. This is the second instance that Michel's words are cloaked. Dissimulation occurs once more, as readers learn that Michel published an essay under his father's name. In Michel's words, he reached the age of twenty-five without going beyond books and ancient ruins, effectively knowing nothing of life. ${ }^{93}$ His cloistered academic world ends as he loses his father, who had set his career in motion and shielded him from real life. Faced with his father's absence, Michel lacks assistance and the shield to which he was accustomed, contributing to his failings in masculine practice. With his adolescence cloistered in books and "ruins," Michel must learn republican citizenship while doing.

Soon after his father's death, Michel takes on — or attempts to - the three most important tenets of traditional French masculinity: being the legal heir and caretaker for his father's estate, marriage, and producing his own heir. Before Michel can move into his own practice of masculinity, his father makes a deathbed request that Michel marry. Sensing his own impending death and possibly his son's nature, Michel's father arranges a marriage of convenience, conceived to keep his son from being alone, thus socializing him and rendering him a citizen in proper standing. ${ }^{94}$ Michel must leave his academic cocoon, at the behest of his dying father, to marry. ${ }^{95}$ This further reinforces Michel's father's deathbed wish as a desperate and final formative act, perhaps one that his father realized he had neglected during Michel's education. Michel takes on the marriage to please his dying father, yet his father's request was not that of a sentimental mind riddled with illness; he was ensuring that Michel would appear appropriate in the face of French

\footnotetext{
${ }^{93}$ Gide, L'Immoraliste, 23.

${ }^{94}$ Ibid, 18.

${ }^{95}$ Ibid., 12.
} 
masculine standards. His father knew that, without marriage, Michel would be subject to the threat of "social abjection" and the "material and symbolic precariousness entailed" therein. ${ }^{96}$ It was not just the desire to socialize his son before dying, but a wish to impose upon Michel "the normative force of conjugality" that marriage was considered. ${ }^{97}$

It is important to note, as mentioned earlier, that heterosexual marriage was considered the motor and manifestation of not only civilization but "moral progress." 98 Being a married man provided Michel with the needed cultural currency to pretend to a position in French society. Furthermore, Michel had to contend with more: He was to reproduce to fulfill the complete French social unit, the family, which involved consummating an otherwise loveless marriage. The marriage is arranged without hassle or romance to Marceline, a young woman whom Michel does not really know:

Je connaissais très peu ma femme et pensais, sans en trop souffrir, qu'elle ne me connaissait pas plus. Je l'avais épousée sans amour, beaucoup pour complaire à mon père, qui mourant, s'inquiétait de me laisser seul. ${ }^{99}$

Michel's father thus attempts to mold his son's masculine performance from his deathbed. Michel acquiesces to make his father's passing more peaceful: "Je ne songeai...qu'à lui rendre sa fin plus douce." ${ }^{\prime 100}$ Read critically, the fact of Michel's marriage occurring as his male role model lay dying provides a multifaceted vision of Michel's masculinity, marriage, and future. Michel recalls the marriage, which prefigures all of his other endeavors to adopt traditional French masculine performance, as a

\footnotetext{
${ }^{96}$ Surkis, Sexing the Citizen.

${ }^{97}$ Ibid.

${ }^{98} \mathrm{Ibid}$.

${ }^{99}$ Gide, L'Immoraliste, 21. (I knew very little of my wife and I thought, without suffering too much, that she did not know me either. I married her without love, mostly to please my dying father who was worried about leaving me alone.)

${ }^{100} \mathrm{Ibid}, 21$. (I only thought... of making his end sweeter.)
} 
mechanical event. Gide describes it as "sans rires, mais non sans grave joie."101 The stages of the ceremony, a short dinner at Marceline's family home and a gathering on the steps of the church as the couple depart in a hired carriage, are without embellishment. Michel tells his friends, as he recalls the past, that only their presence saved the ceremony from the "banale."102

What Michel portrays as the marriage could have been just as easily his father's funeral. More specifically, Michel never discusses his father's death apart from one mention of mourning: "l'indispensable émotion des noces venant sitôt après celle plus réelle de mon deuil." ${ }^{\prime 103}$ Here, Michel finally situates his father's death as preceding the marriage. Michel discusses the emotion of his "deuil" and the wedding in the same sentence, yet he only acknowledges his fatigue: "Ce ne fut que sur le bateau que je pus sentir ma fatigue." ${ }^{104}$ For Michel, the wedding is a perfunctory experience, as suggested by his calling the emotion of the deuil "plus réelle," one that pleased his dying father while inculcating Michel into traditional French masculinity. Further, the process of his becoming "masculine" is inseparable from the funeral for his father. Gide reveals that marriage for Michel signals a transition. Michel lost his father while taking on a wife and now must inherit and adopt the trappings of traditional French masculinity foist upon him by his father's death. Thrust into a world defined by traditional expectations of French men, Michel must improvise his masculine practice to remain relevant.

Michel admits that he begins his adult life postmarriage, knowing nothing of what life could be: “Ainsi j'atteignis vingt-cinq ans, n’ayant presque rien regardé que des

\footnotetext{
${ }^{101}$ Gide, L'Immoraliste, 20. (without laughter but not without serious joy)

102 Ibid, 20.

${ }^{103}$ Ibid., 21. (the essential emotion of the wedding coming soon after that more real of my mourning.)

${ }^{104} \mathrm{Ibid}, 21$. (It was only on the boat that I could feel my fatigue.)
} 
ruines ou des livres, et ne connaissant rien de la vie." ${ }^{105}$ Michel enters into marriage with no knowledge of life: “J'ignorais mes amis, comme je m’ignorais moi-même.” He confesses to having never really paid attention to his friends or himself due to his restricted social life and focus on education. ${ }^{106}$ This is telling, as he admits that he also did not know himself; what he knows of friendship, sentiment, and life are derived from old texts and ruins.

Michel possesses book-learned ideas of nobility, friendship, and faith, as mentioned, and draws from this a model of self. He has no experience with these things; rather, he has rendered them issues of intellect: "Pas un instant ne me survint l'idée que j'eusse pu mener une existence différente ni qu'on pût vivre différemment."107 With this statement, Michel admits to a few things: the hollow nature of his model of self, his naievété about the practices of masculinity that surround him and are expected of him, as well as his ignorance of his authentic self.

Not unlike Michel, Marceline must conform to standards of feminine performance. She must be married and provide an heir while keeping house. Marriage to Michel provides her these opportunities and little more. Michel speaks to his friends of watching her grow up, yet the first time he recognizes her as a distinct being is after their marriage: "Marceline était très jolie. Vous le savez; vous l'avez vue. Je me reprochai de ne m'en être pas d'abord aperçu. ...Pour la première fois je m'étonnai." ${ }^{108}$ To be sure, he notices her, but he is only struck by her beauty and grace; her personality gets no

\footnotetext{
${ }^{105}$ Gide, L'Immoraliste, 20. (So I reached twenty-five, having scarcely looked at anything but ruins or books, and knowing nothing about life.)

${ }^{106}$ Ibid, 12. "I ignored my friends like I ignored myself."

${ }^{107} \mathrm{Ibid}, 24$. (It never occurred to me that I could have lived a different life or that we could live differently.)

${ }^{108} \mathrm{Ibid}, 22$. (Marceline was very pretty. You know it; you saw it. I blamed myself for not noticing it first. ...For the first time I was surprised.)
} 
acknowledgement from him. In addition, Michel shows that he does operate in a more traditional sense; he notices how poor Marceline is and seems to be offended: "Je pris conscience un peu plus nette de ma fortune, mais seulement lors du contrat de mon mariage, et pour m'apercevoir du même coup que Marceline ne m'apportait presque rien." ${ }^{109}$ His offense seems out of place for someone acquiescing to his dying father's wishes. The death of his father and marriage to Marceline seems to have a deeper effect on Michel. His automatic recognition of her beauty and insult at her poverty speak to the germination of something new in him.

Marriage acts as a catalyst in the development of Michel's masculine practice. He leaves a position where no performance is required (his academic cocoon with his father) to a position that requires full investment in the performance and in which all facets of his being are under scrutiny.

\section{Masculinity, Conformity, and Rebellion}

According to historians, the standards of French masculinity are not only out of step with Michel's personal masculine practice but with that of most men. ${ }^{110}$ Masculine standards, as discussed, are understood as culturally informed instructions for performing or being. Michel's unconscious homosexuality factors into his personal struggles with these standards that are out of sync with his person.

Masculine standards weigh heavily on Michel. He evidences a sense of unease deep within, a split between learned heteronormative behaviors and something deeper that evades him and defies naming. Michel, as an unconscious homosexual, only

\footnotetext{
${ }^{109}$ Gide, L'Immoraliste, 12. (I became a little more aware of my fortune, but only during the contract of my marriage, and to notice the same blow that Marceline brought me almost nothing.)

110 Higonnet, Behind the Lines.
} 
recognizes that what he is comfortable with and passionate about is considered immoral and criminal.

Appearing weak was to appear feminine, even in illness. Green-McManus states that in this period, presenting behaviors such as being "limp, tired or lazy is an indication of soft effeminacy." 111 Effeminacy is abhorred, especially for its association to cowardice, something that Michel fears inordinately: "J'ai gardé, je crois, de mon enfance puritaine la haine de tout abandon par faiblesse; je le nomme aussitôt lâcheté."112,113 Michel's response to his own illness fulfills the anxieties expected of 'weak' men. In order to defy his own vulnerabilities, real or imagined, Michel begins to scorn Marceline. He treats the only human with whom he feels a true connection with disdain to realign himself with expectations of masculine behavior. Michel falls ill while on the couple's honeymoon travels. Marceline notices Michel's pallor just before he succumbs, and despite his growing fatigue, he refuses to even appear ill as he starts a conversation with her: “-Tu n'as pas froid, au moins. -Pas trop. Et toi? C'est vrai! Tu es tout pale. -Non." 114 Despite his refusal to be pale, Michel's cough begins that night. He tries to hide his weakness from Marceline, even concocting a story about a bloody nose. As the travel goes on and his illness progresses, he cannot hide, forcing Marceline into a position of power and control to which he cannot abide.

During the nineteenth century, male sexual capability became synonymous with power. ${ }^{115}$ This strict association of male sexual vitality and power meant that a man's

\footnotetext{
${ }^{111}$ Green-McManus, Performing Masculinity, 75.

${ }^{112}$ Nye, Masculinity and Male Codes, 19.

${ }^{113}$ Gide, L'Immoraliste, 17. "I kept, I believe, from my puritanical childhood, the hatred of any abandonment by weakness, I name it immediately cowardice."

${ }^{114}$ Ibid, 17. "At least you're not cold. - Not too much. And you? - It's true! You are all pale. - No."

${ }^{115}$ Nye, Masculinity and Male Codes, 67.
} 
relationships with the opposite sex were directly affected by his perceived sexual vitality. To return their relationship to the proper balance, Michel begins to spurn Marceline as soon as he regains consciousness in Biskra. No matter the state of Michel's masculinity, it is always defined in opposition to Marceline. She acts as the "other," the position of "lack" against which Michel had to prop up and defend his "masculinity." 116 During the worst of his illness, prior to arriving in Biskra, Michel was enchanted with her care:

Entouré de quels soins charmants, protégé, secouru, veillé...de Sousse à Tunis, puis de Tunis à Constantine, Marceline fut admirable. Sa confiance était parfaite; son zèle ne retomba pas un instant. Elle préparait tout, dirigeait les départs et s'assurait des logements. ${ }^{117}$

Michel is aware he would not have survived without his wife or her care, yet within days of regaining consciousness and limited mobility, he begins remarking on her ignorance — she "ne se rendait pas compte que je ne mangeais pas assez"118_ and begins to treat her unkindly:

Mon irritation fut si vive que, la reportant sur Marceline, je me répandis devant elle en paroles immodérées. Je l'accusai; il semblait, à m'entendre, qu'elle eût dû se sentir responsable de la mauvaise qualité de ces mets. ${ }^{119}$

Even the young boys Marceline brings to entertain him are cause for division in Michel's perspective. Michel finds the young boys whom Marceline prefers are calm,

${ }^{116}$ Simone De Beauvoir, Le Deuxième Sexe (Paris: Gallimard Education, 1949).

${ }^{117}$ Gide, L'Immoraliste, 20. "Surrounded by such charming care, protected, rescued, watched over... from Sousse to Tunis, then from Tunis to Constantine, Marceline was admirable. Her confidence was perfect; her zeal did not abate for an instant. She prepared everything, supervised departures and ensured accomodation."

${ }^{118}$ Ibid, 26. "She didn't realize that I was not eating enough"

${ }^{119}$ Ibid, 26. "My irritation was so keen that, transferring it to Marceline, I poured myself out before her in immoderate words. I accused her; it seemed, to hear me, that she should have felt responsible for the terrible quality of the food." 
gentle, and well-behaved, whereas he prefers the boys who are a bit wilder and mischievous, rule breakers and scissor stealers. It is of note that he takes notice of the boys' physicality, noting what he perceives as animality as well as their real nudity prior to their attitudes and characters. This preference for the rebellious aligns with not only scorning Marceline's preferences directly, but with defying weakness and vulnerability. In shunning Marceline and everything she has done or chosen for him, Michel is refusing effeminacy and reasserting that he is not weak.

His inability to further appreciate Marceline is highlighted as her patience, kindness, and long-suffering nature lead him to despise her for what he understands as her conformity, the same defect he senses in traditional masculinity:

De retour près de Marceline, je ne lui cachai point l'ennui que ces fréquentations me causaient. Ils se ressemblent tous, lui disais-je. Chacun fait double emploi. Quand je parle à l'un d'eux, il me semble que je parle à plusieurs. ${ }^{120}$

Not until Michel has embarked on this marriage of convenience do the required practices of masculinity arouse within him a sense of discomfort. Michel cannot name or locate his discomfort, but it manifests as a reflex to reject Marceline, as she represents conventional French culture and conformity. Symptoms of a greater disquiet in his being are his inability to settle into life at La Morinière, his childhood home, or in Paris with his work in academics and social circles:

Dès les premières causeries que nous eûmes, je me vis comme contraint par eux de jouer un faux personnage, de ressembler à celui qu'ils croyaient que j'étais

\footnotetext{
${ }^{120}$ Gide, L'Immoraliste, 104. "When I returned to Marceline, I did not hide from her the boredom that these relationships caused me. They all look alike, I told her. Each one a duplicate. When I speak to one of them, it seems to me that I speak to several."
} 
resté, sous peine de paraître feindre; et, pour plus de commodité, je feignis donc d'avoir les pensées et les goûts qu'on me prêtait. On ne peut à la fois être sincère et le paraitre. ${ }^{121}$

Michel professes to feeling constrained within Parisian society. He confesses to playing a role and not being authentic to himself, instead impersonating what he believes others want to see and know. Marriage acts as a catalyst in the development of his masculine practice. Michel leaves a position where no performance is required (his academic cocoon with his father) to a position that requires full investment in the performance with all facets of his being are under scrutiny. In addition, the marriage acts to disrupt and split Michel's sense of self; he struggles between conformity and anarchy, between Marceline and hedonism.

\section{Michel: Conformity and Hedonism}

The imposition of the masculine ideal upon Michel did not stop with marriage. Despite everything inherent in the position of the married man, standards of masculinity do not stop there. Michel had to contend with much more, as he was to provide an heir, a male child, and manage his inheritance, the family estate La Morinière. At the beginning of Michel's time at La Morinière, when he has assumed the responsibilities of the "heritier" who must manage the family properties, Marceline not-so-coincidentally reveals she is expecting their first child. Throughout the novel, Michel justified his rapport with Marceline with statements such as, "Je l'aimais point... -mais je l'aimais, si

\footnotetext{
${ }^{121}$ Gide, L'Immoraliste., 103. "From the first talks we had, I saw myself as constrained by them to play a false character, to resemble that which they believed that I had stayed, under penalty of appearing to pretend; and, for convenience, I pretended to have the thoughts and the tastes that were lent to me. One cannot be sincere and appear sincere at the same time."
} 
l'on veut entendre par delà la tendresse, une sorte de pitié."122 Upon learning of her pregnancy, his feelings do not change for her; instead, the imperative to protect his potential "heritier" subsumes all thoughts of her.

Under requirements of republican citizenship and French law, only a legitimate male heir could inherit family properties, just as only a man could possess goods and real estate. These legal requirements codified the need for a male child born in wedlock to maintain acquired family goods. As a French man, it is also now Michel's legal and civic duty to provide his own "heritier." The future heir and child are what will finally validate Michel as a model male Republican citizen and eventual patriarch. As Michel meets these pressures with Marceline recently pregnant, his life takes an unexpected turn while residing at La Morinière. Michel has no time to acquire the skills needed to manage people, lands, and the estate's goods, so he turns to the estate's caretaker, Bocage, for information. He meets the caretaker's eldest son, Charles, and finds himself at a loss for words: "Je ne sais plus quel propos nous échangeâmes ce premier soir; occupé de le regarder, je ne trouvais rien à lui dire et lassais Marceline lui parler." ${ }^{23}$ Michel notes that although the boy is 17 , he looks to be no more than 15 , lending an unseemly nature to Michel's burgeoning infatuation. This encounter leads Michel to spend vast amounts of time and effort on Charles. In one of a few homosocial and potentially allegorical experiences, they explore the woods together, and Charles teaches Michel about his own lands: If the land is understood and tended to in an authentic manner, its inherent value will emerge. This rudimentary reference to Michel's latent homosexuality leaves him

\footnotetext{
122 Gide, L'Immoraliste, 19. "If I didn’t love, I say, my fiancée, at least I hadn’t loved any other woman,"

${ }^{123}$ Ibid, 88. "I no longer know what words we exchanged that first evening; busy watching him, I couldn't find anything to say to him and tired of Marceline talking to him."
} 
invigorated. Taking the young man's lead, Michel manages his lands, makes decisions, and acts with confidence: "Je me promenais à cheval, surveillant, dirigeant les travaux, prenant plaisir à commander moi-même, à dominer." ${ }^{124}$

Michel realizes that he yearns for the nonconventional and anti-conformist. Marceline provides not only his tie to mainstream culture but his cover from it. Michel wants for freedom, but he does not seek it outright. Instead, he develops a transient relationship to social mores, to class codes of conduct, and to geography. As a wealthy young man, he must not only adhere to these standards, but must not associate withresist the temptation to seek out—deviants: the criminal, the scandal-ridden and the colonized, or risk ruin to his practice of masculinity, his livelihood, or reputation.

Michel should adhere to social codes that look down on individuals involved in scandal as well as those not of his social class. And yet, while managing his estate, he finds a duality in his character. He follows Charles's lead and, as he describes himself, dominates his lands, yet he finds himself drawn to the actions of delinquents.

This fascination causes him to trail a beautiful transient farm worker, becoming a voyeur and engaging his ire when the listless young man is asked to leave. Marcel transfers his attention to poaching on his own lands and well as seeking out information on a troubled family, the Heurtevents, who work parcels of his land. As a good manager of his family estate, he should employ those who work and are productive and remove those who work not at all or very little. Michel is instead drawn to enjoy the elder Heurtevents indolence: “Ce qui, l'an précédent, m'eût irrité au plus haut point, cette

\footnotetext{
${ }^{124}$ Gide, L'Immoraliste, 97. "I rode on horseback, supervising, directing the works, taking pleasure in giving orders, in dominating."
} 
année me laissait assez calme." 125 Michel enjoys the peace and savage beauty of the woods untouched by man: "Mais ces bois ainsi dévastés étaient beaux, et je m’y promenais avec plaisir, épiant, surveillant le gibier, surprenant les vipères, et, parfois, m'asseyant longuement sur un des troncs couchés." ${ }^{126}$ In lieu of enforcing productivity norms or conforming, Michel revels in the untouched wild woods. This epicurean behavior is at odds with his duties of land management and simultaneously in line with his authentic self. Further illustrating his fascination with the marginalized and decadent, Michel often looks to the example of the young Athalaric, king of the Ostrogoths. The young king died at 18 , a situation attributed to having too early been freed from schooling and made familiar with drink and excess:

La figure du jeune roi Athalaric était ce qui m'y attirait le plus. J'imaginais cet enfant de quinze ans, sourdement excité par les Goths, se révolter contre sa mère Amalasonthe, regimber contre son éducation latine, rejeter la culture comme un cheval entier fait un harnais gênant, et, préférant la société des Goths impolicés à celle du trop sage et vieux Cassiodore, goûter, quelques années, avec de rudes favoris de son âge, une vie violente, voluptueuse et débridée, pour mourir à dixhuit ans, tout gâté, soûlé de débauches. ${ }^{127}$

\footnotetext{
${ }^{125}$ Gide, L'Immoraliste, 104. "That which, last year, would have irritated me to no end, this year leaves me quite calm."

${ }^{126} \mathrm{Ibid}, 104$. "but these woods thus devastated were beautiful, and I wandered there with pleasure, spying, watching the game, surprising the vipers, and sometimes, sitting down for a long time on one of the lying trunks"

${ }^{127} \mathrm{Ibid}, 58$. "The figure of the young king Athalaric was what attracted me the most. I imagined this fifteen-year-old child, secretly excited by the Goths, to revolt against his mother Amalasonthe, to rebound against his Latin education, to reject the culture like a stallion does an annoying harness, and, preferring the society of the uncivilized Goths to that of the too wise and old Cassiodorus, to taste, for a few years, with rough favorites of his age, a violent, voluptuous and unrestrained life, to die at eighteen years old, all spoiled, drunk with debauchery."
} 
Michel's fascination with the young king, as with the Heurtevents, is metonymic for his own desire to break free, to reject conformity and cultural norms of masculine performance, and enjoy a life of his own making. Michel is quickly reminded of his required performance vis-à-vis his infatuation with Athalaric, as Marceline dubs this fascination "sa crise." ${ }^{28}$ Although Marceline lacks malice, she performs the role of heteronormative police, reinforcing Michel's need to see Athalaric's gruesome death as a lesson to remain cloaked and hidden.

\section{Michel's Illness: Conformity and Regeneration}

Michel's illness is metaphoric for his inner health and self-acceptance.

Symbolically, tuberculosis appears and overtakes him on his honeymoon. It is upon diving head-first into a world of traditional expectations - conformity and marriage without his father's protective cocoon that Michel falls ill. Michel's health before marriage was fragile at best, as he spent his life protected by his father in their shared academic world. Marceline, his young, orphan-like wife, attends to his illness and seems complicit in his eventual cure, providing young North African children to amuse him. ${ }^{129}$ Michel does not just suffer from a physical malady; he falls ill due to the constraints of normative culture and social expectations. The strain of conformity has weakened him. Michel understands his discomfort on an instinctual level until discomfort gives way to illness and his illness breaks him. Michel then rejects his wife and develops an impulse for freedom, decadence, and nonconformity to reverse his sure course to death. Michel

\footnotetext{
${ }^{128}$ Gide, L'Immoraliste, 58. (his crisis)
}

${ }^{129}$ Ibid, 32. 
discovers that his cure is to reject normative culture and embrace his inner desires, no matter how they manifest.

Michel begins rejecting traditional culture slowly, if not circuitously. The first indication that he could develop reasonable and non-traditional masculine behaviors is when he begins to speak to Marceline on their honeymoon. He comes to realize that his wife is human, a being worthy of listening to and being listened to; she becomes a true friend:

Nous commençâmes à parler. Ses propos charmants me ravirent. Je m’étais fait, comme j'avais pu, quelques idées sur la sottise des femmes. Près d'elle, ce soir-là, ce fut moi que me parus gauche et stupide. ${ }^{130}$

Michel's first nonconformist act is to reject the popular ideas of women's foolishness and general diminished mental capacity compared to a man's. This evidence of Michel's true self does not last long, as the traditional French masculine ideal would not entertain the capacity of women, including a wife, mother, or daughter, to think on their own. This fleeting glimpse of the real Michel seems to have been too much for him. The dip into less-than-sexist thought also will not last, as Michel begins policing his own "feminine" behaviors at the onset of his illness. As he extinguishes this light, conformity enters and tuberculosis takes over.

Michel's cough begins as he explores Tunis. Rather than accept the care of his wife and newly termed "friend," Marceline, he hides his illness and begins to look at her through a traditional cultural lens, rejecting his earlier appreciation of her as he progresses towards conformity and illness. Michel refuses to allow Marceline to see him

\footnotetext{
${ }^{130}$ Gide, L'Immoraliste, 23. "We started talking. Her charming words delight me. I had, as I could, some ideas on the stupidity of women. Beside her, that evening, it was I who seemed awkward and stupid."
} 
as weak and helpless, perceptions that might effeminize him in accordance with what Lindsay Green McManus, writing about threats to masculinity throughout history, argues: The threat of effeminacy should be countered by a firm masculine manner of movement and stillness. ...Any indication of appearing limp, tired or lazy is an indication of soft effeminacy. ${ }^{131}$

This refusal is born out of the virtues of traditional French masculinity on which Michel places importance. He casts an attitude on Marceline evocative of Simone De Beauvoir's writing. For Michel to be the man that he desires to become, or to pretend to be, he must strip Marceline of her humanity and reduce her to something less than himself. ${ }^{132}$ This regression takes place after he awakens in Biskra, North Africa, where Marceline has taken charge of much of his recovery. Michel fears the effeminate, as noted by his affront to Marceline's leadership as well as the small, insufficient meals she orders. This fear raises another specter: that his nonconformist sense of equality with Marceline is the start of a slippery slope. He must deny his earlier thoughts of her humanity and friendship to perform traditional French masculinity: to conform.

Gide creates a cycle of torture in which Michel's physical health worsens every time he accepts and gives in to the traditional heteronormative culture. He becomes irritated with Marceline's existence, her faith, and her care for him. Marceline, however unwitting, stands in for heteronormative French culture. It is not truly her person that irritates Michel, but what she represents: conformity to a heteronormative world-a world that suppresses his authentic self, imposing artificial codes of masculinity on him

${ }^{131}$ Green-McManus, Performing Masculinity, 75.

${ }^{132}$ De Beauvoir, Le Deuxième Sexe. 
and, ultimately, his health. It is not until Marceline takes the lead and settles them in Biskra that Michel takes his cure in hand and fully rejects Marceline. It is through Marceline, however, that Michel finds his first steps to his cure. She brings home local children to play with and keep her company. Michel also spends his time with these children, finding that they bring an amount of the immoral - lies and theft — that scintillate his spirit. This invigorates Michel, and, eventually, he finds himself cured enough to begin a more robust program of self-rehabilitation.

Michel finds that the further from traditional masculinity he deems his behavior, the better he feels. Michel begins his rehabilitative practice by acknowledging his pale and sickly physique:

Un matin, m’étant mis à nu, je me regardai; la vue de mes trop maigres bras, de mes épaules, que les plus grands efforts ne pouvaient rejeter suffisamment en arrière, mais surtout la blancheur ou plutôt la décoration de ma peau, m'emplit de honte et de larmes. ${ }^{133}$

Michel begins seeking a certain virility by practicing the tenets of the physical culture movement and applying its notions of health and the body to the project of his self-cure:

Je me dévetis lentement. L'aire était presque vif, mais le soleil ardent. J'offris tout mon corps à sa flamme. Je m'assis, me couchai, me tournai. Je sentais moi sous le sol dur. ${ }^{134}$

\footnotetext{
${ }^{133}$ Gide, L'Immoraliste, 66-7. “'One morning, having stripped myself naked, I looked at myself; the sight of my too thin arms, of my shoulders, which the greatest efforts could not throw back enough, but especially the whiteness or rather the decoration of my skin, fills me with shame and tears."

${ }^{134}$ Ibid., 66. "I took my clothes off slowly. The air was sharp, but the sun was fiery. I offered my whole body to its flame. I sat, lay down and turned. I felt myself under the hard ground."
} 
On the rocky outcropping near Ravello, Italy, Michel strips naked and exposes his frail form to the sun, wind, and grasses. This first effort is marked by his frailty and a feeling of being trapped despite his freedom. More specifically, “Je me dévetis lentement" speaks to his illness and weakened state. Gide describes nature, the sharp wind, and the fiery sun in almost negative terms in light of the offering Michel makes. Lastly, Michel feels himself "sous le sol dur," as though he is unable to rise above this state, trapped.

Michel pushes through his illness and sets about a physical cure of his own design. His desire to feel and see, to push his body to accept life again as he rebuilds himself, includes components of physical culture like exercise: "Ainsi me contentais-je pour toute action, tout travail, d'exercices physiques qui, certes impliquaient ma morale changée” and heliotherapy ${ }^{135}$, “je me dévêtis lentement. L'air était presque vif, mais le soleil ardent. J'offrais tout mon corps à sa flamme."136 Similar to Michel's self-directed physical cure, physical culturists, such as Edmond Desbonnet, ran clinics offering a physical cure for what appeared to be late-nineteenth-century masculinity to combat the French man's perceived degeneration. In “Régénération du Snob, ” Figure 2, a gentleman who appears to be of the same social class and delicate health as Michel contemplates his physique in contrast to a sculpture from antiquity. To "cure" his form and rehabilitate his masculinity to a revived ancient ideal, the ideal warrior, he attends a clinic that prescribes Desbonnet's method. His progress is detailed over several months as he advances and completely changes his physique. This evolution far surpasses Michel's, yet

\footnotetext{
${ }^{135}$ Gide, L'Immoraliste, 64. "So I was content for all action, all work, of physical exercises which, certainly implied my changed morals."

${ }^{136}$ Ibid, 67. "I undress slowly. The air was almost crisp, but the sun was burning. I offered my whole body to its flame."
} 
accomplishes an identical goal. The propagandized vision of weak traditional French masculinity must adapt and change to not only regain health, but maintain his validity and survive.

Michel finds that his perspective changes as his version of physical culture and self-cure advances. He no longer finds himself too thin or pale; rather, he now finds something harmonious about his being: "Je me regardai longuement, sans plus de honte aucune, avec joie. Je me trouvais, non pas robuste encore, mais pouvant l'être,

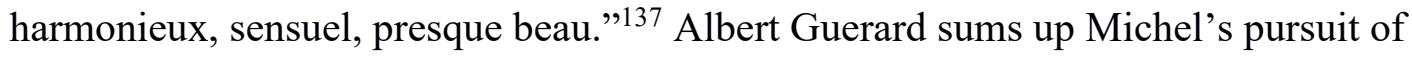
health:

To consider as "right" only what contributes to health is the first phase of his [Michel's] “immoralism." And as health returns, he [Michel] begins to suspect that life has unexplored joys, that he carries within him a precious and unrealized self. He determines to discover this self by a ruthless elimination of everything factitious and acquired. ${ }^{138}$

The self is a palimpsest from which Michel seeks to remove what has been falsely inscribed upon it so that the truth of his original self may be clearly "written." ${ }^{139}$ Michel begins to see himself as liberated, and yet he is still beholden to artifice:

Brusquement, le jour ou je me mis pour la première fois nu sur la roche, cette barbe me gena; c'était comme un dernier vêtement que je n'aurais pu dépouiller...

\footnotetext{
${ }^{137}$ Gide, L'Immoraliste., 69. "I looked at myself for a long time, without any more shame, with joy. I found myself, not yet robust, but capable of being harmonious, sensual, almost beautiful."

${ }^{138}$ Guerard, André Gide, 99-118.

${ }^{139}$ Lucey, Never Say I.
} 
Rentré dans la chambre d'hôtel, je me regardai dans la glace et me déplus; j'avais l'air de ce que j'avais été jusqu'alors: un chartiste. ${ }^{140}$

Michel commits one last act of self-cure in Amalfi, Italy. Removing his final and most literal mask, he shaves his beard: "Sentant sous les ciseaux tomber ma barbe, c'était comme si j'enlevais un masque."141

\section{Propagandized Masculinity}

Gide's depiction of heteronormative French society's restricted vision and practice of masculinity can be further illuminated by heteronormative classifications described and charted by Jean Baptiste Descuret (1795-1872), a French physician and author. His most well-known work was a psychosocial study entitled Médecine des passions, ou les passions considérées dans leurs rapports avec les maladies, les lois et la religion, or the Medicine of the passions; the passions considered in their relation to diseases, laws, and religion. The text, published in 1841, was based on his interactions with thousands of patients in Paris. The text primarily presents the diverse passions and vices of his many patients from a medical, religious, and economic standpoint. ${ }^{142}$

The latter's classification was defined as criminal and socially backward and perverted any practices outside of a narrow scope of sanctioned heteronormativity. ${ }^{143}$

With no room for error, heterosexual masculinity—and femininity—became precarious

\footnotetext{
${ }^{140}$ Gide, L'Immoraliste, 70. "Suddenly, the day I got naked for the first time on the rock, this beard pissed me off; it was like a last piece of clothing that I could not have stripped off. ... Returning to the hotel room, I looked at myself in the mirror and was displeased; I looked like what I had been before: a chartist."

${ }^{141}$ Ibid, 70. "Feeling my beard fall under the scissors, it was like taking off a mask."

${ }^{142}$ Jean Baptiste Félix Descuret, La médecine des passions ou Les passions considérées dans leurs rapports avec les maladies, les lois et la religion, 2e ed. (Paris: Labé, 1844).

${ }^{143}$ Gide, L'Immoraliste, 65-6.
} 
positions to maintain and required relentless performance. To remain free from suspicion, one's performance had to be perfect. Being suspect not only pertained to homosexuality, but to all debauchery and criminality. It is worth noting that Michel spends his time seeking out those he considers immoral. It appears that Michel applies Descuret's judgment and classification system to himself. He pursues those he observes, presumes, or knows to be challenged by vice and criminality. Here, Michel attempts to feel comfortable, to fit in.

Included in the performance of male heteronormativity were marriage, work, and inheritance, all conditions Michel satisfied in the wake of his father's passing. Latenineteenth-century masculinity looked less to the physical manifestation of the man and more to his accomplishment of the aforementioned tasks. There was an emphasis of these civic aspects of masculinity and avoidance of aggression in this period (for example, the duel was increasingly criminalized to prevent male-on-male violence in the name of honor).$^{144}$ The civilian, the man of civic virtues, was to value his duties as a citizen and abstain from violence. Paradoxically, though, his citizenship hinged on the implicit promise to sacrifice himself in armed conflict if the state should ask, thus propagandizing the opposite of the good citizen, the ideal warrior, as France began to see war, as is apparent in the chapter on Celine's Voyage au bout de la nuit. Such threats of war, and thus the warrior-male, were not new creations but were repressed, not unlike Michel. ${ }^{145}$

The propagandized version of masculinity's physical form was accentuated, as visible on the La Baïonnette cover (Figure 21). On the left, the figure of the poilu, discussed in my introduction, is tall, towering over the other man in the image. He has a

\footnotetext{
${ }^{144}$ Nye, Western Masculinities, 418.

145 See Figure 1.
} 
precise posture and his complexion is healthy, with balanced features. He is bearded, or "hairy," as the nickname of the traditional French soldier suggests he should be. To dramatize the "hairiness" of the poilu, the man wears an animal fur strapped over his uniform. The poilu incorporates the fur as a part of the uniform, with his medals proudly pinned upon it rather than hidden under it. Also attached to his person is the helmet of a (presumably) fallen German soldier and a large, prominent rifle. This trophy serves to announce his skill and success on the battlefield, denoting him as a formidable force, while his rifle harkens back to the man's occupation and his dominant status within the image. The poilu's ready, resolute stance and his tattered clothing speak to a fearless and pugnacious nature untroubled by finery. Though the poilu is illustrated as still, even stoic, his potential for action is indicated by his trophy, rifle, and fearlessness.

The figure on the right is his foil, his clear opposite: the civic vision of latenineteenth-century masculinity. Comparable to Michel and his compatriots, this figure represents traditional French masculinity. This man is small in stature and his posture is lacking, owing potentially to a curved or unhealthy spine. His complexion is yellow and pallid and his features are unbalanced, as his nose dominates the rest of his facial features and head. Upon closer inspection, his nose is dripping; coupled with his sallow complexion, his health is now completely in doubt. His clothing is expensive and wellmade, replete with embroidery, tails, ruffles, and gloves. He has the trappings of a wealthy bourgeois gentleman, including an épée at his side. Closer examination of the épée shows that it is bent and otherwise useless, a telling metaphor for the masculinity that carries it. This representative of traditional French masculinity has a weak stance; he 
is drawn trembling, as denoted by the movement shown about his hat. His knees appear bent, further indicating a stance that lacks resolve and vigor.

Finally, there is passivity in this man's actions. He is holding and gesturing to a pamphlet that addresses the subject of the poilu, yet in doing so, demonstrates his weakness and impotence versus the poilu. Moreover, the pamphlet alludes to the lack of physical agency possessed by those who embody traditional French masculinity. Indeed, the latter looked to exterior accomplishments to validate their performance of masculinity: wealth, status, education, marriage, and children. With his education, he can read the pamphlet and "recognize" the virtues of the poilu; with his wealth and status, he might have a position of authority in society from which to tell the poilu what to do. But pretend to the physical agency of the poilu he cannot. He is instead frightened, intimidated by the health, ability, and force that the poilu possesses.

When contrasted to the poilu, the propagandized vision of traditional French masculinity is in decline, and there is little doubt that Michel represents such traditional la baionnette French masculine standards. From the outset, his description is as lacking in health and stature: "Une autre chose que j'ignorais, plus importante encore peut-être, c'est que j'étais d'une santé très délicate." ${ }^{\text {466 }}$ His placid life of academia and studies left him weak: "La vie trop calme que je menais m'affaibilssait."147 Michel's abrupt descent into illness and his self-declared weakness beforehand bring to mind the yellowed complexion, dripping nose, and bent back of the figure of traditional French masculinity in the image. To be sure, late-nineteenth-century standards of masculinity did not require

\footnotetext{
${ }^{146}$ Gide, L'Immoraliste, 20. "Another thing that I didn't know, perhaps more importantly, was that I was in very delicate health."

${ }^{147}$ Ibid., 21. "The too calm life I was leading had made me weak."
} 
a physical component aside from biology. However, threats to France's sovereignty, such as the Franco-Prussian war, created serious insecurity in the French male body. The physical health and prowess of the French man were now of clear importance for France's very existence. Late nineteenth-century masculinity was pushed aside in favor of a more vigorous, warrior-like masculinity. Traditional French masculinity, such as Michel's, was not up to the task of defending France, as shown in the La Baïonnette art. Michel's application of physical culture brings about his health and his vigor and, more importantly, foments his sense that there is another way to be. Michel seeks not to attain the ideal warrior as propagandized (Figures 1 and 2), but to leave behind the weakened traditional French man, as seen in Figure 1. As Guerard suggests, Michel begins to chase that which causes him to manage his health ruthlessly, with no regard to the consequence, including Marceline's death. Michel is desperate to strike a balance between his health, his deeper self, and the world in which he lives, and yet he fails. Although Michel succeeds in regaining his health, enjoying his diverse vices, and ridding himself of "everything factitious and acquired," his success comes at a cost he did not expect. ${ }^{148} \mathrm{He}$ finds himself alone, with no possessions, calling out to friends for help. Before her death, Marceline made a point that, while lost on Michel, is critical:

Ne comprenez-vous pas que notre regard développe, exagère en chacun le point sur lequel il s'attache? et que nous le faisons devenir ce que nous prétendons qu'il est. $^{149}$

\footnotetext{
${ }^{148}$ Guerard, André Gide, 99-118.

${ }^{149}$ Gide, L'Immoraliste, 169. "Do you not understand that our gaze develops, exaggerates in everyone the point on which it is attached? and that we make it become what we claim it is."
} 
Michel sees only what he wants—-his health, his vice, his pleasure—in each person involved in his life. His insistence on his own happiness leads him to look to the past, to reexperience and reclaim the joys of his healing and awakening when no one left in his life can easily offer these things to him. Michel finds that he cannot reclaim the past, as his friend Ménalque put it: "Le souvenir est une invention du malheur." ${ }^{150} \mathrm{He}$ fails at recovering his past joys, but he succeeds in another way: He performs masculinity that defies classification. Michel proves these "opposing" ideas coexist, counter to JBF Descuret's classifications of vice. He represents not only traditional French masculinity but a rehabilitated French masculinity that offers another path: neither the ideal warrior nor the weakened traditional French man. In his nonconformity, Michel challenges and negotiates the two most prevalent masculine performances available to him. He eschews the duties of French civic life and regains his health. Michel prefigures a physical self that will be validated and propagandized through the war effort, although not until late in the effort. ${ }^{151}$

The man in Figure 7 is Claude J. Rouget de L'Isle, a man enlisted in the French Army at the time of the French Revolution. He was, however, not a "poilu," but an engineer, poet, composer (la Marseillaise, among other songs), and author. His image in this liberation loan poster does not appear until 1918, the last year of WWI. He represents a vision of traditional French masculinity that, unlike the representative in Figure 1, is healthy, intellectual, and courageous. This new man is a construction who appears again in Colette's Chéri in the figure of Fred. Fred, like Michel, is not the poilu, nor does he

\footnotetext{
${ }^{150}$ Gide, L'Immoraliste, 172. "memory is an invention of sadness."

${ }^{151}$ See Figure 7.
} 
completely fit the mold of weakened traditional French masculinity. Like Michel, he bridges the gap and returns a war hero, symbolically validated. 
Chapter Two: Colette And Her Muse of MAsculinity: CHÉRI AND LA Fin DE CHÉRI

Sidonie Gabrielle Colette (1873-1954) was a prolific French author, actress, journalist, and mime. She was well known for her Claudine series and Gigi. Colette's two novels that concern this study are Chéri (1920) and Le fin de Chéri (1926), which she published in the middle of her career. Written after WWI, the novels indicate the shift from pre-war to post-war life among a group of courtisanes whose status and way of life is quickly disappearing. Chéri is the vision of bourgeois masculine practice, a representative of the pre-war center. However, as his nickname connotes, his masculine practice is decidedly at odds with propagandized masculine norms that would pervade French society shortly before the war and with his tenure as a soldier. Through Colette's depiction of his practice of masculinity in Chéri and La Fin de Chéri, readers acquire a vision of pre-WWI traditional French masculinity as well as the alterity accepted within it. Colette's deliberate choices in Chéri's description — physique, behavior, and character - tell a distinct story of difference and credible authenticity in the pre- and postWWI periods. In addition, Colette's ensemble of characters in the two novels all present gendered behaviors that do not adhere to traditional and propagandized standards of masculinity or femininity

Chéri concerns the hidden relationship between Belle-Epoque courtisane Léa and Chéri, also known as Fred Peloux. Léa is, at minimum, 24 years Chéri’s senior as well as a competitor and friend of Chéri's mother, Charlotte. At the outset of the novel, the relationship has been ongoing for six years. The relationship is poised for change, however, as Chéri's mother and Marie-Laure, another courtisane, are working out the financial details of Chéri's marriage to Edmée, Marie-Laure's daughter. After their 
marriage, Léa withdraws to the countryside, telling no one. Chéri is depressed by her absence and shocked at the youth and innocence of his young bride. He constantly compares her to Léa, who has been gone for at least three months. After a fight with Edmée, Chéri heads to his friend Desmond's home, staying for three months and paying for drugs and women he neither uses nor enjoys.

Chéri chooses to return to his home with Edmée when he learns that Léa has returned to Paris. As Léa tries to reestablish her life in Paris, she tries to avoid thoughts of Chéri. Chéri, however, cannot stay away. He visits Léa, who lets him into her home, and the couple spends one last night together. The night's passion and commitment fade with the dawn as Chéri looks upon Léa and realizes just how much she has aged. The unresolved issue of their age difference causes a final row between the lovers. Chéri attempts to discuss Léa's age, putting her in her place when she objects. The novel ends when Léa shows Chéri the door, hoping in vain that he will look back as he leaves. Instead, he walks briskly away and breathes deeply, like a man who has just won his freedom.

Le fin de Chéri picks up with Chéri, Léa, Edmée, and Charlotte six years after Chéri. WWI has ended and Chéri has returned from serving, an uninjured hero. He feels out of place in his own home with a wife who has found her voice and identity and a mother who is liberated. While Chéri was away fighting, Edmée ran the home, began nursing work at a hospital, and engaged in infrastructure and charity projects with Charlotte. Chéri finds himself aimless and lost without a war to fight or Léa to distract him. He cannot adapt to the new positions his wife and mother occupy or the role, or lack thereof, he is to play. 
Chéri tries to catch up with Desmond and relive the past but finds that his friends have moved on and desire to focus on the present. Chéri searches to escape from his life but returns to obsessing over Léa. He ventures to see her and finds her overweight, with short gray hair and dressed like an elderly matron. When he leaves, he meets an old acquaintance, the Pal, who offers him her flat so that he might have some alone time. Chéri fills a wall with old photos of Léa and spends countless nights staring at them. Instead of succumbing to the past, Chéri makes one last attempt to connect with Edmée: He asks if she would like to have a child. Edmée is aghast at his question and refuses.

Realizing that every aspect of his former life is over, Chéri visits his mother. Although Charlotte understands her son's anguish, she can do nothing for him. Chéri notices that, for the first time in his life, his mother is tearing up and possibly even sad for him. Chéri retreats to the Pal's flat and the pictures of Léa. He spends a few moments reminiscing about the world in which he used to have a place before ending his life.

The characters Colette develops in each novel detail the shift in French gender norms between the decadence of the fin-de-siècle and the inter-war period. This shift is keenly apparent when examining Chéri, Léa, and Edmée (and, to a lesser extent, Charlotte) across the two works. Each character develops in a nonlinear manner except for Chéri. Chéri's character progresses across the novels while following an unswerving path. Before the war, he glides from interaction to interaction with grace and poise, relying heavily on his masculine privilege to negotiate life. In this same pre-war period, masculine privilege affords him latitude, respect, and agency, no matter his performance of masculinity, which could be described as dandyism, far from the masculine practice 
propagandized prior to and during WWI. Chéri's investment in each of his interactions with others is, at best, superficial and perfunctory.

Chéri is a demimondaine, always cloistered in his mother's eccentric circle of friends who, while monied, are somewhat marginalized from polite French society and function as a sort of makeshift family. Seen through Chéri's eyes, this group calls to mind something along the lines of the Island of Misfit Toys. Composed of delicate men, strong women, and absentee parents, the group allows him every indulgence and provides no real care, discipline, or structure. The group acts as another opportunity for Colette to create the world as it was lived and not idealized, showing no allegiance to traditional gender performances. His upbringing lends to the image of a man-child who flexes his traditional French masculinity (read: superiority) among the mondaine society in which he is raised and indulged. This early sense of self-importance carries over into his dealings with the outside world. Chéri is described in some critical analyses as birdlike ${ }^{152}$ or as a stereotypical misogynist or a queer figure ${ }^{153}$, and he is all these things and more. Chéri enacts his masculinity in ways that would not normally strike the reader as traditionally masculine, yet his behavior is buoyed by his privilege, his mother's money and bourgeois pretentions, his biological gender, and, most importantly, by the women who surround him. His mother, Charlotte, allows him every trespass, and his lover, Léa, aids and abets his feminine proclivities and dandyism despite her desire to inculcate him to traditional French masculine practice. Chéri displays decadent masculinity that is at once in line with traditional patriarchal France and decidedly alternative.

\footnotetext{
${ }^{152}$ Marcelle Biolley-Godino, L'homme objet chez Colette (Paris: Klincksieck, 1972).

${ }^{153}$ Todd Reeser and Lewis Seifert, Entre Hommes: French and Francophone Masculinities in Culture and Theory, 1st ed. (Newark: University of Delaware, 2008), 168.
} 
Much of Chéri's behavior is emblematic of the dandy. Garelick states that the dandy, as a phenomenon, predated the fin-de-siècle and spanned from England to France. Further, the dandy engaged in a performance that went above and beyond that of his gender. Dandyism is itself a performance, the performance of a highly-stylized, painstakingly-constructed self, a solipsistic social icon: "[Dandyism] announced and glorified a self-created, carefully controlled man whose goal was to create an effect, bring about an event, or provoke a reaction in others through the suppression of the natural."154

Chéri's performance of masculinity is indeed carefully manufactured and painstakingly furbished. With attention to his attire, personal grooming, and overall appearance, Chéri crafts his performance as a dandy by avoiding the natural. He seeks luxury and comfort, acquiring it by cutting a well-appointed figure. Biolley-Godino affirms that Chéri's profession "est de n'en pas avoir." 155 His efforts are those of a man who does not care for work in any measure and merely enjoys seeing and being seen. For him, instead of using the "regard de l'autre" to shape an identity that conforms to masculine norms, the "regarde de l'autre" is sought after to validate the effect his grooming and behavior have on those around him.

Colette demonstrates that because Chéri is male, he can easily take on almost any performance without suffering. Chéri transgresses accepted gender performances in silks and suede while demanding his mistress's pearls. As Lawrence Schehr suggests, Chéri performs masculinity for himself as much as for the outside world: "Il se tenait devant un miroir long, appliqué au mur entre les deux fenêtres et contemplait son image de très

\footnotetext{
${ }^{154}$ Rhonda K. Garelick, Rising Star: Dandyism, Gender, and Performance in the Fin-de-siècle (Princeton: Princeton University Press, 1998), 3.

${ }^{155}$ Biolley-Godino, L'homme objet, 50. "is to not have one."
} 
beau et très jeune homme." ${ }^{156}$ In fact, it is exactly this that Colette is highlighting: Chéri's performance of masculinity has no bearing on cultural gender norms.

\section{Belle Epoque Chéri vs. Propagandized Masculinity}

Colette presents Chéri as a traditional French man enacting bourgeois masculinity according to the standards of the pre-war period. Critics have argued that he is homosexual; however, it is only upon comparing his performance of a highly-stylized, vanity-driven, and petulant masculinity—-that of a dandy— to masculinity as propagandized by the war effort that Cheri seems not as a queer figure but as homosexual. The analysis of Cheri as homosexual is attributed to him due to his stylized performance of masculinity. From the perspective of dominant notions of masculinity, Chéri's attention to grooming, his less-than-traditional masculine comportment, and his obsession with his looks all conspire to invite questions about his sexuality. Colette instead offers ambiguity about Chéri's sexuality. The author describes him with terms generally reserved for women and young girls, such as "preening" and "petulant," showing him to be a preening blackbird, an angry nursling, and a swaggering narcissist. From Colette's descriptions, it is unclear whether she means for Chéri to appear as a virile object of desire or an ungracious child. Reeser and Seifert state, "Chéri thus escapes categorization, being neither a 'classical homosexual' nor a 'macho man.' What Colette ultimately portrays is the breakdown of a bourgeois heterosexual masculine ideal." 157

\footnotetext{
${ }^{156}$ Sidonie-Gabrielle Colette, Chéri, trans. Stanley Applebaum (Mineola: Dover Publications, 2013), 1. "He stood in front of a long mirror, placed against the wall between the two windows and contemplated his image of a very handsome and very young man."

${ }^{157}$ Reeser and Seifert, Entre Hommes, 33.
} 
I agree that Chéri could represent the breakdown of the bourgeois heterosexual masculine ideal; however, I believe that was Colette's express intention: not to show the breakdown of such, but instead to demonstrate that, objectively, this ideal never existed. From the beginning, he primps, observes the world around him with disdain, and enacts his masculinity in ways that would be considered queer compared to propagandized wartime French masculinity, but speak to the performativity of the dandy. This behavior also brings to mind the earlier figure of the flâneur, putting oneself together with the express purpose of seeing and not doing: "In making himself (en se faisant) a dandy, a man becomes a piece of boudoir furniture, an extremely ingenious mannequin, who can sit upon a horse or a sofa...but a thinking being...never." ${ }^{158}$ Colette describes Chéri physically as striking, yet fragile, but never in terms of purposeful activity or intellectual prowess and certainly not in terms of work. To this point, Chéri is always dressed impeccably, buttressed by his inheritance, and inspired by the latitude granted by his biological gender and social position within the demi-mondaine society that envelops him. Illustrated by Lea's estimation of Chéri: “Jamais son jeune amant ne l'avait surprise défaite, ni le corsage ouvert, ni en pantoufles dans le jour." 159

Because of his biological sex, Chéri can perform masculinity in any way he pleases and his status is not affected. Although he does not provide, lead, or advise, Chéri's authority, agency, and dominance over women remain highly traditional. Within the novels, what might seem a perceived conflict between his vanity and his traditionally male status vis à vis the women in his life is a "non-dit." For Chéri, "Being a man

\footnotetext{
${ }^{158}$ Garelick, Rising Star, 18.

${ }^{159}$ Colette, Chéri, 16. "Her young lover had never surprised her undone, neither the bodice opened nor in slippers during the day."
} 
depends as much on the sensuality of his masculinity as it does on the gendered aspects of his existence." 160

\section{Colette's/Chéri's Women}

The women in Chéri's life-his wife, mother, and lover-all occupy places of marginality, and all find themselves, at some point, victims of Chéri's calculating nature, his authority due to biology, or his deep-seated vanity. Woman for him is the "other," one to overlook (his mother, Charlotte), conquer (his wife, Edmée), and take for granted (his lover, Léa). Garelick explains,

Decadent dandyism seems to leave no space for the woman. It prizes perpetual, artificial youth and a reified, immobilized self. By virtue of their association with the human life cycle and reproduction, women threaten the dandy's eternal presence with temporality and hence become objects of fear and disdain. ${ }^{161}$

Garelick again invokes the subject of nature in terms of age and reproduction.

Chéri never seems to age; he is referred to in both novels as "Chéri," a moniker gained during his peculiar childhood amongst the demi-mondaine community to which his mother belonged. In contrast to Chéri's seemingly perennial youth, from the opening scene of Chéri, Léa frets over the loss of her looks due to aging. Chéri appears to be surrounded by women: his mother, his lover, his fling, and his bride-to-be.

Interestingly, there are no characters who fill the age gap between Chéri and his mother: Léa is approximately his mother's age, and Edmée is much younger than her husband. I suggest that this age gap, this empty space, is symbolic of the dandy's

\footnotetext{
${ }^{160}$ Reeser and Seifert, Entre Hommes, 165.

${ }^{161}$ Garelick, Rising Star, 5.
} 
immortalized youth and his overall inability to move forward, to cope with decay and mortality. Importantly, the feeling that Chéri is trapped in a place from which he cannot escape is reflective of the changes in gendered practices portrayed by the women around him. The diverse women in Chéri's world age and evolve, yet Chéri seems eternally paused.

The opposing traits of femininity portrayed in Chéri are a severe contrast to Chéri's selfish and childish masculinity. Chéri's wife, Edmée, is the picture of submissiveness and child-like innocence, whereas his lover occupies the opposite end of the gender spectrum. The aging courtesan, Léa, is strikingly dominant in her actions, at times more masculine in her performance than Chéri. The theme of aging dominates much of Léa's inner monologue. She obsesses over her outward appearance and dress, which she needs to attract potential clients. Not unlike the advertising poster, Léa uses herself, her commodified self, to secure her future. A direct comparison is possible between Léa and the advertising poster for France Champagne ${ }^{162}$.

The commodification of the young woman in the poster is much the same as Lea's personal commodification. The poster's composition is specifically to attract a buyer, most likely a young man. The young woman's hair is slightly uncoiffed while her coup de champagne overflows. Not only does the poster suggest that the young woman is interacting with the onlooker via her direct and smiling gaze, but her décolleté is visible without shame as her fan is closed, eschewing modesty. Further, her champagne has left her coup and flooded the foreground of the poster, making a direct connection with the onlooker. Léa, as a courtesan of the same period of the advertising poster who would

\footnotetext{
${ }^{162}$ See Figure 2.
} 
have been similarly dressed and styled, sought her high-end patrons by complementary means. Her availability and performance of femininity would have been on display for potential patrons, not unlike the presentation of the advertising poster.

Léa is in her late forties at the outset of Chéri and is terrifyingly aware of the closing window of her livelihood, as illustrated in many scenes, not unlike this one:

Le "Madame est belle" qui ne lui déplaisait pas. "Belle..." se disait Léa en montant au boudoir. Non. Plus maintenant. A présent il me faut le blanc du linge près du visage, le rose très pâle pour les dessous et les déshabillés. Belle... Peuh...je n'en ai plus guère besoin..." Pourtant, elle ne s'accorda point de sieste dans le boudoir aux soies peintes, après le café et les journaux. Et ce fut avec un visage de bataille qu'elle commanda à son chauffeur: "Chez Madame Peloux." 163 As this scene shows, Léa undertakes a certain subterfuge to maximize her looks using colors, textures, and lighting before she can no longer fight against the advances of aging. Léa's present state of mind is made clear in Colette's word choice of "bataille" to describe her. She chooses to battle the conventions of age and prescribed age-appropriate feminine performances. The natural conclusion is that aging will win this fight, and then what will her performance of femininity matter?

Chéri's mother, Charlotte, is a contemporary of Léa but appears to have settled with little fuss into the conventions of middle-aged French femininity. She was a danseuse herself and potentially a courtesan like Léa, but with Chéri’s birth, seems to

${ }^{163}$ Colette, Chéri, 9. "The "Madame is beautiful" who did not displease him. "Beautiful..." Lea said to herself, going up to the boudoir. No. Not anymore. Now I need the white of the linen near my face, the very pale pink for the underwear and the negligees. Beautiful...Phew...I hardly need it anymore ... "However, she did not take a nap in the boudoir with painted silks, after coffee and newspapers. And it was with a face of battle that she commanded his driver: "Chez Madame Peloux." 
have yielded to a more culturally acceptable performance of femininity. It would be incorrect to compare her to traditional French feminine performances as she is still considered a demi-mondaine, an outsider to mainstream French culture and society. Yet, she is Colette's chosen portrayal of ineffective maternity. Charlotte looks the part yet has no authority over her son and never has:

Chéri connut donc toutes les joies d'une enfance dévergondée. Il recueillit, zézayant encore, les bas racontars de l'office. Il partagea les soupers clandestins de la cuisine. Il eut les bains de lait d'iris dans la baignoire de sa mère, et les débarbouillages hâtifs avec le coin d'une serviette. Il endura l'indigestion de bonbons, et les crampes d'inanition quand on oubliait son dîner. Il s'ennuyait, demi-nu et enrhumé, aux fêtes des Fleurs où Charlotte Peloux l'exhibait, assis dans des roses mouillées. ${ }^{164}$

In this choice, Colette demonstrates that "l'habit ne fait pas le moine" (the robes do not make the monk). Although Charlotte may dress the part of the traditional French mother/woman, she is far from it. She preferred to use her child as a prop, a distraction, and otherwise, something to avoid when faced with difficult decisions regarding him.

Edmée's innocence lasts only until Chéri must leave for war. Although she has no need to maintain pre-war conventions in her life or marriage, Edmée makes a choice to keep her dress and hairstyle as they were before the war. Edmée does not need to update her hair to the popular bob, smoke, or wear men's clothes to enhance her agency or

${ }^{164}$ Colette, Chéri, 15. "Chéri therefore knew all the joys of a wanton childhood. He collected, still lisping, the low tales of the pantry. He shared the clandestine dinners in the kitchen. He had iris milk baths in his mother's bathtub, and hasty cleansings with the corner of a towel. He endured the indigestion of candy, and the cramps of starvation when his dinner was forgotten. He was bored, half-naked and cold, at the Flower festivals where Charlotte Peloux exhibited him, sitting in wet roses." 
authority, as many of her contemporaries would. Edmée shows that a full inversion of the center and margin is not necessary to take or display agency. Colette's choice for Edmée to maintain the trappings of pre-war French femininity once again demonstrates that the outside and the inside do not have to match. Edmée is strong and resilient in the face of a crippling war. She forges her own path and sheds any perception of herself as submissive or dependent. The choice to illustrate a range of femininity within these two novels allows Colette to emphasize the spectrum of gendered performances that populate her text as well as exemplify the variations that exist outside of her novels.

The pre-war gender dichotomy, although ambivalent in practice, is traditional in the enforcement of power structures. Colette's choice to open Chéri with Chéri's claim to Léa's pearl necklace, his petulant demand to wear it, and his whine to possess at least one pearl from it frame the ambivalent nature of gender that permeates the writing. Colette constructs Léa as the maternal, the erotic, and the masculine within these same first few pages. Léa denies Chéri's request for the pearls as he throws a fit, yet she reacts as though his childlike tantrum is normal, even expected.

This opening scene paints an unexpected equivocation of the predictable pre-war gender dichotomy. Chéri’s feminine comportment: lounging on Léa's bed like an Amazon, draping her pearls about his person, pirouetting about her chambers and Léa with her parental, dismissive, masculine stance in refusing him this trinket. On the one hand, in her actions, Léa refuses him the ability to co-opt her femininity and deconstruct her identity by wearing and taking apart her pearls. On the other hand, Colette tactfully employs ambivalence to gendered actions to set the tone for negotiating multifaceted gender identities, as seen in both Chéri and La Fin de Chéri. This does not occur in a 
void. Colette presents a mirror of real life in her works. Colette was known to express fluidity with gendered behaviors and performances (see Figure 4). The choice to open the novel with this particular performance highlights the fluidity with which Chéri can exercise gendered behaviors, in stark contrast to Léa, who must maintain, at all costs, her reputation, which she has built upon a fixed exercise of gendered performance. In short, the young bourgeois man may flirt with any performance he wishes while Léa, even in private, must supervise her own.

Further analysis of the pearls themselves highlights the complexities in Léa's and Chéri's interactions. As a courtesan of high repute, Léa did not receive payment from her callers; rather, they would provide "gifts" of jewelry, homes, carriages, and even horses. The pearls were the lavish "gift" of a former caller, the monetary transaction between the caller and Léa for her physical presence and potential sexual performance. Chéri covets that which Léa must monetize and negotiate, not her pearls, but herself. Léa is pragmatic; she knows she must continue her profession as long as her beauty sustains it to prepare for retirement. Léa cannot deny age and temporality. For this reason, she cannot hand her pearls to Chéri, not even one. She cannot become his alone or she will not survive.

Léa further acknowledges Chéri’s less-than-traditionally masculine physique as well as his lack of coordination with the boxing lesson. Léa arranges a lesson with her dear friend, le Patron, a boxer, to assist Chéri in developing the skills he is lacking. Léa all but admits to her belief in Chéri's masculine deficiency by arranging this lesson, knowing he will struggle and sulk but insisting he needs it to buttress his masculine identity. In this, Léa admits to a fault in Cheri; 
Ah! oui, je me rappelle, je vais faire venir Patron le boxeur, pour entraîner ce petit. Nous avons le temps, Patron d'un côté, moi de l'autre, de bien épater Madame Peloux. ${ }^{165}$

In addition to arranging and overseeing this physical education, she performs the maternal role in Chéri's regard. It is not her role as his secret lover to teach him to be a man, to mother him with structure, scolding, or lessons, yet she does all these things. The boxing lesson itself is a comedy act as well as a tacit admission of his masculine shortcomings, as judged by Léa and Patron. Chéri's efforts to undertake the skills taught are pitiful, and he is again petulant and sulky. Chéri immediately attacks the instructor from a position of class and wealth. With his bitter reaction, he assaults the instructor's social status, denigrating the boxer's physical prowess and specialized skill to appease his own bruised ego and eye. However, his ability to analyze the situation stops there.

A closer look at the boxing lesson shows that it is not unlike the opening scene, when a childish Chéri demands Léa's pearls. His bourgeois privilege and status have left him inept and callous, his argumentative abilities paradoxically stunted by his vanity. Chéri is accustomed to getting his way, which has reduced his capacity for reasoning to demands and petulant fits. With this scene, Colette offers another view of bourgeois French masculinity as inept.

This episode also allows Colette to provide an image of working-class French masculinity to the gendered types she explores. The boxer is tall, broad, and plainspoken; he is the character foil of Chéri. As Chéri's opposite, the boxer's silhouette

\footnotetext{
${ }^{165}$ Colette, Chéri, 23. "Ah! yes, I remember, I'm going to bring Boss the boxer, to train this little one. We have time, Boss on one side, me on the other, to impress Madame Peloux."
} 
evokes the propagandized vision of "le Poilu." ${ }^{66}$ Patron admires Léa, and, in many ways, they are homologous characters. Much like his friend, the boxer does not come from a background of wealth or reputation; both characters represent the working classes. He relies on his body and a set of specialized skills and practical intelligence to earn his living. He must make his way in the world as Léa does, with his body and not money, reputation, or status. They both offer their physicality as currency to survive while sublimating their egos to the wealthy and entitled because the transactions to earn their livings take place with the moneyed classes.

The boxing lesson is a window into Chéri's performance of gender and of his own identity. Cheri's dandyism should be flawless and well-appointed: a master of his emotions, not only superior to others but also more interesting and unique. This is incompatible with weakness or failure, and still, Chéri misses a block during the lesson. Patron lands a jab squarely on Chéri's fine jawline, finding it deceptively delicate rather than firm. Chéri immediately resorts to insulting the boxer on a personal and social status level when he is incapable of following the lesson by accomplishing a simple move. Chéri loses more than his self-control and composure; the veneer of his dandied masculine performance has ruptured. His facade of bourgeois masculine superiority has cracked and his identity is shown to be deficient, as Léa knew it would, much as Colette makes apparent throughout the two novels. Further, analysis of this scene begs the question: Did Léa know that Chéri would be tested by more than her own doubts? Perhaps she realized that a burgeoning conflict, such as WWI, would require a seasoned, less-fracturable Chéri able to depend on something more than his bourgeois upbringing

\footnotetext{
${ }^{166}$ See Figure 21.
} 
and education. It is also possible that she simply organized this lesson out of concern for his masculinity, which she judged deficient. However, I believe it was Colette's choice to have Léa seek this education for Chéri to symbolically catalog Léa's understanding that times are changing and Chéri must be able to adapt if he is to survive.

Between these two examples, the pearl and the boxing lesson, Colette demonstrates that Chéri's bourgeois masculinity, and more so his dandyism, cannot compete in either scenario. These two examples of pre-war traditional French masculinity are outmoded as they are based on status and money that permit a man to be inept, physically and emotionally. Pre-war standards of masculinity might have allowed a young man like Chéri to flourish, yet the harbinger, as Léa correctly deduces, will give rise to standards for men that will disqualify any performance of femininity. Cheri's performance of dandyism and pre-war bourgeois masculinity are doomed with the coming conflict.

\section{Spectrum of Femininity}

Chéri's female characters Edmée and Léa further illustrate the spectrum of prewar gender that Colette presents. Léa strikes a strong, effortless practice of masculinity without injury to her femininity. As a courtesan, she is at once on the precipice of femininity and scandal; thus, her masculine behaviors do not reflect on her practice of femininity. She is set apart from the standards that fall upon the typical French woman. The standards that govern Léa require her hyper-feminine performance toward her potential courters, yet she is free to follow her thoughts, read, write, and manage her own finances. Léa's profession is in decline, as her retirement approaches symbolically with the changes that WWI will require of her and of French society. 
Edmée, Chéri's young wife, represents the opposite end of the gender spectrum: pre-WWI submissive femininity. She is guileless in behavior and agency. Through her arranged marriage to Chéri, she transfers her obedience from her domineering mother to her self-indulgent and vainglorious husband. Although Edmée seems entirely naive and beholden to Chéri, her mother-in-law, Charlotte, notices something about her that serves as a foreshadowing for the state of affairs in Colette's sequel:

Je me demande vraiment, je me demande s'il n'y a pas la, dans l'avenir, un danger pour mon fils. Je crains, ma Léa, je crains qu'elle [Edmée] n'arrive à éteindre trop cette nature si originale. ${ }^{167}$

In the sequel, La Fin de Chéri, the situation is reversed, as feared. Chéri is the returned war veteran who finds himself marginalized, entirely dependent on his formerly acquiescent wife. The margin has become the center. In a comparative analysis of the two novels, it would be easy to cast Chéri's once-diminutive wife and her modern attitude as aggressive and feminist. Similarly, Chéri's turn from spoiled and misogynistic to overlooked, taken-for-granted, conquered, and, finally, suicidal could indicate symptoms of war trauma. The New Woman, as represented by Edmée in La Fin de Chéri, examines the wartime transfer of power and gender identity that took place in post-war France.

In La Fin de Chéri, literary figures such as Chéri illustrate the difficulties many returning veterans faced when confronted with a newly modernized society. The nameless narrator in Henri Barbusse's Le Feu faces the same crisis of belonging. He and his fellow soldiers have the sensation that they, when faced with civilization, are, as

${ }^{167}$ Colette, Chéri, 123. "I really wonder, I wonder if there is not, in the future, a danger for my son. I fear, my Léa, I fear that she [Edmée] will be able to extinguish this original nature too much..." 
Chéri says of himself, "tout aussi à part," 168 no longer seeing a place for themselves in the society they have fought for and no longer seeing that this society has need of them. ${ }^{169} \mathrm{In}$ the essay "Soldier's Heart," Gilbert she discusses the wartime power transfer that Colette illustrates between Chéri and Edmée. Gilbert states that the men of WWI were "increasingly alienated from their pre-war selves," while for France's women, the war "offered a revolution in economic expectations, a release of passionate energies, and a (re)vision of social and aesthetic dreams." ${ }^{170}$ The modernized society, born out of war, was shaped by the New Woman, who worked outside of the home, cut her hair, and was independent.

I suggest that Edmée acts not as a woman seeking to subvert traditional French society by means of burgeoning feminism. Through the liberty, responsibility, and independence the war at once gave and demanded of her, she represents the newly shifted center. Her actions suggest that she is not broaching traditionally masculine-dominated areas of French culture/society with the intent to subvert these institutions. Rather, Edmée fits into Inter-War France's female social fantasy with her work as a heroic, angel nurse. Rather than disruptive, Edmée's behavior is in line with the new normal. Edmée does not seek authority, agency, or to supplant Chéri. Instead, she evolves, moving forward in her personal development while Chéri stagnates in his pre-WWI behavior.

\footnotetext{
${ }^{168}$ Colette, La Fin De Chéri. (All just as separate)

${ }^{169}$ Henri Barbusse, Feu (Folio Plus Classique) French ed. (Paris: Gallimard Education, 2007).

${ }^{170}$ Sandra M. Gilbert, "Soldier's Heart: Literary Men, Literary Women, and the Great War," Signs, 8 (1983), 422-50.
} 


\section{The Margin and the Center}

As La Fin de Chéri shows, the margin is now the maladjusted returning soldier, the former bourgeois gentleman and dandy who has no place in post-war French society. Chéri seeks to return to his position of pre-war dominance: to the way things were. Yet, he is unable to function within his marriage due to the power shift that has occurred between himself and Edmée. She

has not only taken on new working and sexual identities, and is in financial control of the household, but also seems to Chéri to be selfishly indifferent to his anguish, and is unable, or unwilling, to understand when he attempts to express his feelings of disaffection and isolation. ${ }^{171}$

The war-weary man who returned to re-occupy the center finds himself displaced, lost, taken for granted, and dependent on the formerly childlike wife he left behind. Chéri is now the other, the feminized.

Chéri, in particular, presents not only the veteran disillusioned by the society and home life to which he has returned, but also the veteran suffering from neurasthenia, or shell-shock. Veterans with emotional traumas faced social ostracization simply for being war veterans as well as a complete emasculation when diagnosed with or treated for hysteria, a traditionally feminine malady. As a traditionally feminine problem, the only solutions were traditionally feminine treatments. ${ }^{172}$

Chéri is furthermore haunted by the death of his fellow soldier, Pierquin, compelled to repeat Pierquin's death in his head when speaking and dreaming. It is not

\footnotetext{
${ }^{171}$ Allison Fell, "Life after Léa: War and Trauma in Collette's Fin de Chéri," French Studies LIX, no. 4 (2005), 495-507.

${ }^{172}$ Brandon Moblo, "Failed Men: The Postwar Crisis of Masculinity in France 1918-1930, Student Summer Scholars 7 (2008).
} 
the experience of Pierquin's death that haunts Chéri, but the peace and nothingness Pierquin had achieved. Chéri longs for that same state; he seeks to repeat his wartime traumas. In Beyond the Pleasure Principle, Freud attempted to justify veteran's compulsions. For Freud, the subject who is "locked in a state of compulsive repetition, [he/she] is possessed by the past and faces a future of impasses." ${ }^{173}$ Freud explained thanatos, the death drive, as an urge to return to a blissful state of desire-free passivity. The compulsions to repeat and relive wartime traumas were attempts by the veteran to “"master' or 'bind' painful experiences retrospectively." ${ }^{174}$ Chéri is frozen in a pattern of compulsive repetition, reliving, retelling, and re-experiencing Pierquin's death. He makes efforts to see Léa, hoping to revisit their relationship, yet she has moved on much like the war has ended. Time has dispatched the past and taken Chéri with it.

Chéri and his wife, Edmée, show an unexpected consequence of the war: the shift of the center and the margin in gender relations. Faced with a wife upon whom he is dependent, a society that has rejected him, a past upon which he is fixated, and a compulsion to seek the nothingness of Pierquin's death, Chéri commits suicide. I argue that Chéri's suicide amid photos of a past that no longer exists is a metaphor for the death of pre-war dandyism and bourgeois French masculine practice. Similarly, those who could not cope with the evolution of French society induced by the war itself were left in the margins. The new world had no room for them. Collette frames pre-war dandyism and bourgeois French masculinity as having a choice in the face of this changing world: adapt or die. Chéri does not show a similar resiliency or adaptability. His formation in a rigid social structure allows him no flexibility of mind or spirit to adapt to his new, post-

\footnotetext{
${ }^{173}$ Fell, Life after Léa, 495-507.

${ }^{174}$ Ibid.
} 
war reality. The New Woman, a product of her environment—of survival—was an adaptation. Her arrival at the center, even for a brief period, speaks not to feminism but to the social need for the New Woman in the face of daunting circumstances. 
ChaPter Three: The ANTI-Hero AND THE REJECTION OF SOLDIERING AS MASCULINITY

IN CÉLINE’S VOYAGE AU BOUT DE LA NUIT

Louis Ferdinand Celine contributed his experiences and personal spin on interwar novels with Voyage au bout de la nuit, published in 1932. In the first chapter, his antihero, Ferdinand Bardamu, becomes entangled in the pomp and circumstance of a WWI military parade. In a propaganda-fueled state of mind, he joins the frenzy and marches off with the other soldiers. Unlike Gide's Michel, Bardamu finds himself drawn subconsciously to confront standards of French hegemonic masculinity. In a rash decision, informed primarily by alcohol and the cultural standards of masculinity he has internalized, Bardamu makes what can only be seen as a deluded choice: He enlists in the war effort. He leaves his civilian life as a medical student and, in a sense, begins his life of flight. Bardamu embarks on a circular trajectory that will take him across three continents.

Céline describes Bardamu's trajectory as a soldier. First, he falls victim to propaganda-fueled recruitment, a military parade of pomp and circumstance, abounding with standards of traditional French masculinity that ensnares his subconsciously malecoded daredevil sensibilities. The cultural ideal of the soldier, of what it means to be a soldier, as well as the definition of what is considered a "real" man, traps him in reluctant service. Second, he observes that so-called heroism has only put him in danger and requires that he kill Germans, other men who have never personally harmed him; a soldier's job is to take orders.

American Lt. Colonel David Grossman explains in his book On Killing, "The id wields Thanatos like a club and screams at the ego to kill. The superego appears to have 
been neutralized, for authority and society say that now it is good to do what has always been bad." ${ }^{\prime 175}$ The successful soldier can take orders, kill on command, and take normally forbidden actions by suppressing his ego. Therefore, the successful soldier is a good man, whereas a soldier who cannot take orders to kill and follow through is not a man. Masculinity in the interwar period was highly tied to soldiering performance, as Céline's novel shows. During WWI, this soldiering performance echoed across multiple propaganda posters.

Figures 1, 2, 8, and 9 present soldiers in varying situations, from battle and leave to enlistment. Closer consideration of each reveals the soldiering standards against which Bardamu is measured. The common thread among all four propaganda posters is the performance of masculinity, specifically soldiering masculinity, represented by its imagery. In Figure 1, the soldier leaps from a trench, calling to his comrades, "On les aura!” (They will get them!). The young man seems almost happy to fulfill his duty, killing Germans he does not know, a notion that renders Bardamu physically ill. Figure 2 is an enlistment call for French-Canadian men, pictured here as strong, happy, and welcoming to those who will join them. This propaganda poster clearly shows that although England may need their physical help, the men bear a deeper burden. The men represent the progeny of heroes of old: "les Compagnons de Dollard, des soldats de Montcalm, et de Lévis, les fils des vainqueurs de Châteauguay et les frères des heroes de St. Julien et de Festubert." ${ }^{\prime 16}$ This call to their ancestral, almost totemic, fearless lineages leaves room for nothing but the heroic soldiering of men. If masculinity is a myth, no

\footnotetext{
${ }^{175}$ Dave Grossman, On Killing: The Psychological Cost of Learning to Kill in War and Society Unabridged (Boston: Little, Brown \& Company, 2009), 37.

176 "The companions of Dollard, the soldiers of Montcalm, and of Lévis, the sons of the vanquishers of Châteauguay and the brothers of the heroes of St. Julien and Festubert."
} 
more than a socially and culturally informed performance, this poster re-emphasizes on the mythologizing of masculine heroism, creating a paradox by calling on mythos to reinforce the modern myth of masculine performance.

Figure 8 enforces other aspects of accepted masculine performance: heterosexuality, matrimony, and fatherhood. Analyzing this image presents two more standards of masculine performance, protection and sacrifice. The soldier depicted is strong and uniformed, shown to be a father and husband. His young daughter embraces him tightly while he faces away from the viewer and toward his family. The soldier's body becomes a physical barrier between his wife and two children and the individual viewing the poster. This image makes the very real assertion that only by the soldier's body, his fight, and potential sacrifice would his cherished ones, and even France, be safe. Again, Bardamu falls short in this aspect. His failed relationships with Lola, Musyne, and Molly provide no matrimony or progeny, as he was quick to leave each one before a sacrifice was required.

Figure 9 presents the ultimate vision of the French soldier, the Poilu, or hairy one. The Poilu is tall, strong, and physically imposing. He wears a tattered uniform covered with animal furs and smokes a pipe, with medals affixed to his chest and a war trophy, a German helmet, lashed to his belt. Bardamu's battlefield experiences center around when he can possibly escape and remove himself from the madness he finds in war. He erroneously receives a medal for heroism during a desertion attempt. In truth, Bardamu accomplished none of the propagandized masculine performances. He failed at such culturally and socially informed performances as a soldier and should thus logically fail as a man. Indeed, Céline created an anti-hero defined by his failure: first as a soldier, and 
then his inability to adopt accepted practices of masculinity. The character of Bardamu was one meant to fail in accepted endeavors of masculinity. He represents Céline's protest against warfare, further understood as his protest against traditional French masculinity. Bardamu ultimately finds the French ideal of the heroic soldier/man, who lays his life on the line at the request of the nation, to be hollow and itself a propagandized foolishness. However, his ego will eventually belie his propensity for cowardice.

As stated earlier, Judith Butler's theory of performativity states that "gender proves to be performance - that is, constituting the identity it is purported to be. In this sense, gender is always a doing, though not a doing by a subject who might be said to pre-exist the deed." ${ }^{177}$ In this explanation, gender is not what or who people are but what they do. Because there is no natural connection between sexuality, gender, and sex, biology is not destiny; thus, it is impossible to be a sex or a gender. Instead, every social/cultural conception of male/female is illusory, an act. ${ }^{178}$ The gendered categories of male and female are then social constructions, arbitrary categories produced by cultures that influence how individuals are "written." Cultural norms influence each category and how it relates to another category or even has power over categories. Bardamu seems aware of the game of pretend in which he is involved aboard a passenger ship taking him to Africa. In this instance, Bardamu performs masculinity correctly, to a calculated effect:

Capitaine! lui répondis-je avec toute la voix convaincue dont j'étais capable dans le moment, quelle extraordinaire erreur vous alliez commettre! Vous! Moi!

${ }^{177}$ Butler, Gender Trouble, 25.
${ }^{178}$ Ibid. 
Comment me prêter à moi, les sentiments d'une semblable perfidie? C'est trop d'injustice en vérité! J'en ferais capitaine une maladie! Comment? Moi hier encore défenseur de notre chère patrie! Moi, dont le sang s'est mêlé au vôtre pendant des années au cours d'inoubliables batailles! De quelle injustice alliezvous m'accabler capitaine! ${ }^{179}$

When tormented by the other passengers and treated as a sort of "bouc emissaire," or scapegoat, for imagined trespasses, Bardamu claims innocence from imagined crimes aboard the Amiral Bragueton. His survival depends on playing to the myth of masculinity, building up the hero. Bardamu makes full use of this tactic, keeping danger at bay, preying on the passengers' vanity: 'Il n'y a pas d'homme non plus qui ne soit pas avant tout vaniteux." ${ }^{180}$ In playing upon their arrogance, he invokes heroes of modernity: Là où les plus magnifiques soldats de notre race se sont couverts d'une gloire éternelle. Les Mangin! les Faidherbe, les Gallieni! ${ }^{181}$

Bardamu recalls Figure 2, the enlistment call to French-Canadians, by using the names of vaunted heroes to assuage the patriotic anxieties of his fellow passengers. Whereas Figure 2 calls upon heroes of old who have passed into legend and myth with few to recall their true natures, Bardamu uses the names of French military men who are considered heroic yet whose troubled conduct is not forgotten. I believe this is a deliberate statement on the absurdity of heroism by Céline. The names Bardamu invokes

${ }^{179}$ Céline, Voyage au bout, 134. "Captain! I replied with all the convinced voice I could do at the moment, what an extraordinary mistake you were going to commit! You! Me! How can I lend myself to the feelings of such perfidy? It's too much injustice really! I would make of it, Captain, a disease! How? 'Or' What? Me, who, yesterday, was still a defender of our dear fatherland! Me, whose blood has mixed with yours for years in unforgettable battles! What injustice were you going to overwhelm me, Captain!"

${ }^{180}$ Ibid, 137. "There is no man who isn't above all, conceited."

${ }^{181}$ Ibid, 134. "Where the most magnificent soldiers of our race have covered themselves with eternal glory. The Mangins! Faidherbe, Gallieni!" 
are all French military commanders and colonial administrators. These are men who attained glory for France while subjugating native populations, with one even earning the nickname "the Butcher" (Mangin). Ironically and absurdly, Bardamu ensures peace and nonviolence for himself by invoking figures of great violence.

When the horrors of battle prove too much, Bardamu plans to escape the battlefield, deciding the only valid heroism is that of self-preservation. His escape plans begin as soon as he engages in battle. His desire for self-preservation is irreconcilable with standards of masculinity. Every French male born since the Revolution was automatically a soldier, thus when asked, the French man was to rise to the occasion and fight or give his life for the Republic. To refuse was considered un-masculine, antiheroic, and ultimately an act of cowardice. Within the first 14 pages of the novel, Bardamu ponders desertion 14 times, as he realizes that "this madness" will never end and cannot be rationalized, "La guerre en somme c'était tout ce qu'on ne comprenait pas." 182 Bardamu seeks to apply logic to the devastation, death, and meaninglessness he faces in battle. As an academic, a medical student, he desires balanced actions and consequences, evidence and conclusions, things the war cannot provide. Bardamu concludes that there is no explaining who dies, why the country is obliterated, and what good it will do the world at large. Instead, he acknowledges the absurdity of war and the fallacy of the hero.

Traumatized and seeking a way out, he meets Leon Robinson and the pair hatch a plan to desert together. The plan fails as Bardamu is reassigned and then injured. $\mathrm{He}$ returns to Paris to convalesce and treat his wounds. Ludicrously, Bardamu receives a

\footnotetext{
${ }^{182}$ Céline, Voyage au bout, 10. "War is, in summary, all that cannot be understood."
} 
medal for injuries incurred during his botched escape attempt. The absurdity Bardamu associated with killing innocent strangers appears again in the absurdity of receiving a medal for trying to escape. The ridiculousness of his "heroism" is further compounded when Lola, the young American nurse he meets while healing, encourages him to head back into battle. Bardamu encounters similar difficulty with Musyne, a French pianist who loses interest in him when he refuses to reengage with the military.

Instead, Bardamu runs to Africa and encounters his deserter friend, Robinson. Africa is far from the utopian free state of nature Bardamu imagines and even further from the wealthy colonist's paradise to which his employer alluded. Rather than finding man in a natural state, free of the decay that Bardamu associates with culture and modernity as epitomized by the war, he finds the same misery, exploitation, and death he chose to avoid in embattled France.

From Africa, Bardamu heads to America. He takes a factory position in Detroit and experiences his first deep emotional connection with Molly, a sex worker, about whom he says:

Je l'aimais bien, sûrement, mais j'aimais encore mieux mon vice, cette envie de m'enfuir de partout, à la recherche de je ne sais quoi, par un sot orgueil sans doute, par conviction d'une espèce de supériorité. ${ }^{183}$

Molly's work brings her into contact with the same decay that Bardamu claims to flee_-as he states, his “desire to flee from everywhere." Molly has fled conventional feminine life and performs femininity to her own standards. Bardamu sees no ill in this

${ }^{183}$ Céline, Voyage au bout, 261. "I liked her, surely, but I liked my vice even better, this desire to run away from everywhere, in search of I don't know what, by a stupid pride no doubt, by conviction of a kind of superiority." 
profession and no vice in Molly as he will later see in sex workers in his medical practice. Perhaps Molly is exempt due to her flight from convention as a self-made woman. Despite the appeal of the unified labor force (an attraction that holds due to Bardamu's vague communist/fascist sympathies) and the love of his life, Bardamu leaves Detroit. He finds, again, death and despair in the mechanization of Detroit's factory life:

C'est pas la honte qui leur fait baisser la tête. On cède au bruit comme on cède à la guerre. On se laisse aller aux machines avec les trois idées qui restent à vaciller tout en haut derrière le front de la tête. C'est fini. Partout ce qu'on regarde, tout ce que la main touche, c'est dur à présent. Et tout ce dont on arrive à se souvenir encore un peu est raidi aussi comme du fer et n'a plus de goût dans la pensée. ${ }^{184}$ When factory life brings Bardamu down, Molly's love and wealth are not enough to hold him steady. In fact, her wealth compared to his meager wages exposes an unexpected traditional facet of his masculinity. Bardamu works to hold himself against the grain of the average man, the hero or warrior. He is a self-declared "lâche," or coward: an anti-hero. However, as evidenced in his feelings over Molly's generosity, he has not cut all ties with an ego based in more traditional masculine practices and performances:

Elle [Molly] possédait d'amples ressources, cette amie, puisqu'elle se faisait dans les cent dollars par jour en maison, tandis que moi, chez Ford, j'en gagnais à

\footnotetext{
${ }^{184}$ Céline, Voyage au bout, 255. "It's not shame that lowers your head. We give in to noise as we give in to war. We let ourselves go to the machines with the last three ideas that remain left to wobble high up behind the forehead. It's finished. Wherever you look, whatever your hand touches, it's hard now. And everything that we manage to remember a little is also stiffened like iron and no longer has a taste in thought."
} 
peine six. ...J'avais même honte de tant de mal qu'elle se donnait pour me conserver. ${ }^{185}$

Bardamu feels he is already broken, set on a path to misery by his earlier experiences with the war, Lola, and Musyne ${ }^{186}$ :

On devient rapidement vieux et de façon irrémédiable encore. On s'en aperçoit à la manière qu'on a prise d'aimer son malheur malgré soi. C'est la nature qui est plus forte que vous, voilà tout. ${ }^{187}$

He is more attached and dedicated to his miserable disposition and self-loathing than to Molly's love:

Mais il me semblait que je commençais alors à tricher avec mon fameux destin, avec ma raison d'être comme je l'appelais, et je cessai dès lors brusquement de lui [Molly] raconter tout ce que je pensais. ${ }^{188}$

However, the explanation is not so simple; he is potentially also bothered by appearances. As her boyfriend, a kept man whom Molly takes care to dress well, Bardamu worries about being seen as her pimp:

Cette Molly, toute de même quelle femme! Quelle généreuse! Quelle carnation! Quelle plénitude de jeunesse! Un festin de désirs. Et je redevenais inquiet. Maquereau? Que je me pensais. ${ }^{189}$

${ }^{185}$ Céline, Voyage au bout, 168. "She [Molly] had ample resources, this friend, since she was making a hundred dollars a day at the house, while I, at Ford, earned barely six. ...I was even ashamed of how much trouble she was going through to keep me."

${ }^{186}$ Ibid., 171.

${ }^{187} \mathrm{Ibid}, 259$. "One becomes rapidly old and in an inexorable way. One notices this in the way that one is taken with loving their own misery in spite of oneself. Nature is stronger than you, that's all."

${ }^{188}$ Ibid, 260. "But it seemed to me that I was starting to cheat on my famous destiny, with my reason for being as I called it, and I suddenly stopped telling her [Molly] everything I thought."

${ }^{189}$ Ibid, 175. "This Molly, what a woman! How generous! What a complexion! What fullness of youth! A feast of desires. And I became worried again. Pimp...? I thought of myself." 
I analyze this in relation to the one aspect of his relationship with Molly that he admits bothers him: her wealth versus his poverty. ${ }^{190}$ He would have to be truly emancipated from standards of traditional masculinity to accept Molly’s generosity unvexed. Bardamu is ashamed to make less than Molly, and no amount of love or gifts will assuage his ego. He is unable to go a day without thinking about how it must seem to others for him to be a "kept man" or, potentially, a "pimp." I suggest that not only does Bardamu prefer misery to company, but he is set in traditional modes of French masculine thought, behavior, and external perception. Despite Molly’s unconditional love, wealth, and desire for his happiness, he cannot remain in the relationship. Her femininity and the imbalance of traditional gender roles lead Bardamu to continue his flight. Molly is the epitome of a liberated woman with agency and success. She is the dominant partner in the relationship; thus, Bardamu becomes passive, marginalized, and feminized. His only agency in this imbalanced and nontraditional equation is to leave. Although this rebalances the equation, it also addresses what Bardamu considers his "fameux destin" that calls him to vagabondage: "Je l'aimais bien, sûrement, mais j'aimais encore mieux mon vice, cette envie de m'enfuir de partout."191

Up to this point, Bardamu's movement has been away from what no longer holds hope for him of a world free of modern decay and human misery. He comes full circle on his last flight to Paris to finish his earlier medical studies, eventually opening a clinic in a poor neighborhood. With this final escape, Bardamu accepts his fate: He must look upon the death and decay of the world, the absurdity he has tried to escape since the war, as it will follow him if he tries to escape again. To be sure, Bardamu chooses his profession

\footnotetext{
${ }^{190}$ Céline, Voyage au bout, 168.

${ }^{191}$ Ibid, 260. "I loved her, surely, but not more than I loved my vice, this desire to flee from everywhere."
} 
despite it bringing him into proximity with the certainty of human decay and misery and perhaps the only things he can reconcile as true.

The practice of medicine is the choice to confront and fight human misery and death itself. This implies understanding human misery as a multifaceted assailant occurring in the biological, physical, socioeconomic, and cultural realms. Instead of confronting this facet of his work, Bardamu seems to disassociate his humanity from that of his patients, applying normalizing discourses about gender to them. It is possible he dissociates, not unlike a soldier on the battlefield or a veteran suffering from various PTSD complications, which he. More troubling is the possibility that instead of dissociating, he sees his patients as contributors to their problems; he has potentially given up his humanity while trying to escape the world's decay. While engaging in an artifice of the modern world he claims to hate, he dehumanizes those who seek his assistance.

Bardamu blames his patients for their miseries, regardless of circumstances, viewing them through the lens of modern cultural decay to which he was once so sensitive. For example, he decides that a sex worker he helps through one in a series of abortions is not a victim; rather, she must be a lustful proponent to her pathology, something he never ascribed to Molly. Bardamu did not completely reject modernity or the ideological underpinnings of it. His attitudes in dealing with the young woman convey popular pseudo-scientific notions of the time, such as degeneration and the decaying French race and the reactionary declaration that shorter skirts lead to infertility. The absurdity of the situation is not lost on Bardamu, who insists that the young woman go to the hospital to save her life, but her parents refuse to save their reputation. He 
proclaims, “Quelle honte! L'hôpital! Quelle honte, Docteur! À nous! Il ne nous manquait plus que cela! C'est un comble!"'192

The absurdity continues when Bardamu sexualizes her while she hemorrhages in her bed:

Ses belles cuisses longues et veloutées...sont quelque chose de tendrement volontaire et de precisement gracieux dans les mouvements qui compte les femmes bien balancées sexuellment. ${ }^{193}$

With his actions, he strips her of her humanity, leaving only the physical form afflicted by her sex: "Ses goûts pour les coïts comme peu de femelles en ont."194,195 In Bardamu's perspective, Molly is not at the mercy of a culture or system that privileges masculine wage-earning, reputation, and life over a specific cultural/moral perspective; she is simply a beast burdened by biology. The young woman's life should not be less important than her parents' reputation, yet his thoughts and actions are contradictory. He removes her agency by treating her like a sheep; she cannot act, speak, or feel independent of her sexuality and, in Bardamu's view, her biology. Bardamu sees only violence and misery in the world and, by his thoughts and actions, enacts violence on those with whom he comes into contact, stripping them of their agency and humanity.

Reflecting on Bardamu's relationship with Molly shows none of these contradictory thoughts toward her, her profession as a sex worker, or her biology.

\footnotetext{
${ }^{192}$ Céline, Voyage au bout, 295. "The shame! The hospital! The shame, doctor! For us! That's all we're missing! It's just too much!"

${ }^{193}$ Ibid, 259. "Her beautiful long and velvety thighs ... are something tenderly, voluntary and precisely graceful in the movements that count women as well balanced sexually."

${ }^{194}$ Ibid., 259. "Her taste for sex as few women have."

${ }^{195}$ Sex here is to be understood as her biological sex; Bardamu relates this to the prevalent notions in the period that women were lustier, with vicious sexual appetites that would devour a man's virility.
} 
However, this relationship occurred before Bardamu's return to France and the completion of his medical studies.

\section{Life, Death, and the Absurd}

As Bardamu describes, the French army might have trained him to kill, but they did not succeed in training him to enjoy killing: "On avait même fait tout pour me donner le goût"196 In contrast to other soldiers who seem to enjoy killing, he presumes the French army should have spent more time initiating him to the practice:

Certains soldats bien doués, à ce que j'avais entendu conter, éprouvaient quand ils se mêlaient aux combats, une sorte de griserie et même une vive volupté. Dès que pour ma part j'essayais d'imaginer une volupté de cet ordre bien spécial, je m'en rendais malade pendant huit jours au moins. Je me sentais si incapable de tuer quelqu'un, qu'il valait décidément mieux que j'y renonce et que j'en finisse tout de suite. Non que l'expérience m'eût manqué, on avait même tout fait pour me donner le goût, mais le don me faisait défaut. Il m'aurait fallu peut-être une plus lente initiation. ${ }^{197}$ (See Figure 30)

What becomes apparent about Bardamu is not that he cannot kill or that he finds it morally objectionable, but that he becomes physically ill when considering killing as a desirable act. This quote reveals two things. First, according to the law, a French man is considered a soldier from birth; he is under immense pressure to be accepted as "bon

\footnotetext{
${ }^{196}$ Céline, Voyage au bout, 91. "They did everything to get me to like it."

${ }^{197} \mathrm{Ibid}, 91$. "Some very gifted soldiers, from what I have heard, experienced when they joined the fighting, a sort of intoxication and even a lively pleasure. As soon as I tried to imagine the pleasure of this very special order, I made myself sick for at least eight days. I felt so incapable of killing someone, that it was definitely better that I give it up and finish it right away. Not that I had missed the experience, they had even done everything to give me the taste, but the gift was lacking. Maybe I should have had a slower initiation."
} 
pour le service" (see Introduction) and to perform French masculinity while soldiering. Second, the military is not only teaching the new soldiers to kill, according to Bardamu but engendering a sense of passion in their commission of duties while presenting it as patriotism. Céline's description of Bardamu prior to his enlistment engenders a portrait of a young pre-war Frenchman who is not a dandy, as we see with Chéri, nor working class (he is a medical student) and yet not especially suited for physical labor or hardship. Céline's portrait of Bardamu is that of a young man enacting pre-war French masculinity with no particular desire to prove his patriotism by any means other than sarcasm. What he learns is that, although legally considered a soldier since birth and having potentially already faced the Conseil de Revision (see Introduction), he is not prepared. Céline illustrates that a young man with a greater than average education is no more prepared to face war than any other young man.

I suggest that Céline's statement on pre-war masculinity is analogous to Colette's: Pre-war masculinity faces the choice to adapt or die. For Colette, Chéri will elect to die and leave a world that no longer has room for him. For Céline, the world of man requires choices composed of absurdity. Bardamu will run to evade these choices until he finds there is no space left for him that is untinged by absurdity. Both authors produce and expound upon very different performances of pre-war French masculine practice with similar outcomes. Although the character's practices contrast with one another, the results of their participation in WWI are complementary. Chéri and Bardamu leave their respective service heroic yet disenchanted, disillusioned, and trapped in a moral dilemma that appears to be hidden from those who surround them. Only Molly seems to offer any grace for Bardamu's particular inclination or understanding of his torment. 
A government propaganda effort so focused on the war itself leaves no reprieve for the soldiers' post-war experience. The sheer brutality of the war and the advent of mechanized warfare left more soldiers dead than in past European wars and just as many traumatized to the point of what was then called hysteria, shell-shock, and, today, PTSD. These results can explain how the war and its absurdity affected Bardamu. He was unable to find any logic in or rationalize the war effort: "La guerre en somme c'était tout ce qu'on ne comprenait pas." 198 His disassociation and dehumanization of others, coupled with his frequent flights, speak to shell-shock or PTSD.

Bardamu appears committed to his dehumanized and disassociated pursuit of the absurd until the death of Bébert, whom he considers an innocent child. Bardamu undertakes Bébert's care with determination incongruous to his being. Bébert captivates Bardamu with his joy and optimism: "Sur sa face livide dansotait cet infini petit sourire d'affection pure que je n'ai jamais pu oublier. Une gaieté pour l'univers." ${ }^{199}$ It is this innocence that Bardamu sets out to save, and when he cannot, he capitulates to the misery that surrounds him.

This is not the first unfortunate situation Bardamu encounters in his work; however, it is the first that causes him to revert from his acquiescence to the world's misery and decay to his former wartime lament: that there is no fairness, no mercy, and no logic in this world. From this point, Bardamu's perspective is no longer that of “misery happens, disassociate and forge on." He willingly becomes mired in a murder

\footnotetext{
198 Céline, Voyage au bout, 10. (War is, in summary, all that cannot be understood.)

199 Ibid., 275. "On his pale face danced that infinite little smile of pure affection that I could never forget. Cheerfulness for the universe."
} 
scheme that requires his complicit and willing participation. The agency necessary to take part in this scheme and commit murder is a reversal of his former modus operandi.

Bardamu deviates course for a fourth time, coming full circle in embracing his own agency. He began as a willing participant in the war, volunteering his service. Once he is embroiled in the war and its inescapable death, destruction, and decay, his status as an active participant quickly transitioned to active flight, running from what he judged to be a world tainted with decay and death. Once back in France, from his perch as a doctor, he passively discerns and involves himself in the world's decay. This final course, though, ultimately restores Bardamu as an active participant following the death of Bébert. Rather than pursue illusions of masculinity, flee death and decay, or simply observe and judge the outcomes, he now actively pursues a path that causes death and destruction.

Bardamu switches from being a passive witness of the world's madness to an active participant. Bardamu has stayed just out of range from much of this same madness and decay but to involve himself at this point suggests that Céline views these outcomes as inescapable. With Bardamu's training as a doctor, he just as likely could have used his specialized skills for good as an active participant in correcting some of the world's madness. However, for this to have been the outcome, that masculinity would have to be authentic, not in crisis; masculinity would have to be a means through which subjects enact something more than the death and decay that Bardamu witnessed in the war, an experience instigating his flight of escape and searching around the globe.

Céline purposefully presents a vision of interwar masculinity in Bardamu that is not up to the standards of pre-war French masculinity. The character revels in rejecting 
pre-war French masculinity and attempts, across continents and hemispheres, to find a place where he can avoid decay and destruction and feel at ease with humanity and himself. Bardamu uses each new location on his global trajectory as an escape from the prior one.

Beaujour ${ }^{200}$ argues that Bardamu's actions present him as "a passive actor" in his own life. However, as my analysis shows, Bardamu actively chooses to leave each location and embark on every new stage of his life. His movements are deliberate. Bardamu's initial departure to the military, beginning his cycle of flight, is a direct result of his cultural "inebriation," drunk on wine and the propagandized masculinity of the military parade. He mocks the culture that would sacrifice volunteers to the warring agenda of elites, yet jumps headlong to join the military on a dare to prove himself correct. The propaganda of the military parade and the hero myth convince him of his eventual vindication and celebration. His opening debate with his friend, Arthur, summarizes the underlying theme of the novel: that masculinity is a scam and the hero is a myth created to consecrate the death and destruction from which man cannot escape:

Haineux et dociles, violés, volés, étripés et couillons toujours, il nous valaient bien! Tu peux le dire! Nous ne changeons pas! Ni de chaussettes, ni de maîtres, ni d'opinions, ou bien si tard que ça n'en vaut plus la peine. On est né fidèles, on en crève nous autres! Soldats gratuits, héros pour tout le monde et singes parlants, mots qui souffrent, on est nous les mignons du Roi Misère. C'est lui qui nous

\footnotetext{
${ }^{200}$ Michel Beaujour. “Céline, artiste du laid,” The French Review 38 no. 2 (1964), 180-90. http://jstor.org/stable/385212
} 
possède! Quand on est pas sages, il serre. ...On a ses doigts autour du cou, toujours, ça gêne pour parler, faut faire bien attention si on tient à pouvoir manger. ...Pour des riens, il vous étrangle...C’est pas une vie! ${ }^{201}$

Bardamu's speech comes within the first five pages of the novel, delivered while watching the military parade with Arthur, thus foreshadowing the life about which he will soon embark. He refers to men, the "on" in the above quote, in general as mistreated, passive, and unable to change their socks, let alone opinions and masters. He declares that men are born faithful to ideas of propagandized masculinity and the hero myth and will suffer for it as soldiers, who are no more than talking monkeys. The "faithfulness" to which he refers may be better understood as guilelessness. The innocence of the general French population is apparent in Arthur and Bardamu as they discuss the benefits and drawbacks of "doing their part" for the war effort. Bardamu does enlist as a "faithful" citizen; he voluntarily becomes a soldier but feels he is supposed to behave as a talking monkey, as if he could to perform tasks, such as murdering Germans, on command without remorse. Of course, this analysis of what men are can extend to his friend Arthur, who does not enlist. The expectation is still that Arthur is a faithful citizen if not a soldier, and he will still likely suffer for decisions his government makes that impact or even end his life.

${ }^{201}$ Céline, Voyage au bout, 5. "Hateful and obedient, raped, stolen, gutted and yet creeps, they were worth us! You can say it! We are not changing! No socks, no masters, no opinions, or so late that it is no longer worth it. We were born faithful, we die! Free soldiers, heroes for everyone and talking monkeys, words that suffer, we are the cute of King Misery. He's the one who owns us! When we are not wise, he squeezes ...We have his fingers around his neck, always, it gets in the way of speaking, you have to be very careful if you want to be able to eat. ...For nothing, he strangles you. ...This is not a life!" 


\section{La Lâcheté}

Bardamu is a self-declared "lâche." In cultural and historical terms, lâche (coward) is the worst insult to French masculinity. ${ }^{202}$ However, Bardamu does not view his behavior as a lache to be unacceptable; he redefines the word from an insult into one of praise: "Serais-je donc le seul lâche sur la terre? pensais-je. Et avec quel effroi." ${ }^{203}$ To be lâche for Bardamu is to see clearly the absurdity of the war. However, on the heels of WWI, lâche, or cowardice, is an especially painful attack on a masculinity considered to be in decline and crisis-laden. Bardamu recognizes that his practice of masculinity clashes with cultural expectations, and he deserts the war, but not because he is ashamed. Rather, cultural expectations of heroism as being able to withstand violence and killing are precisely what Bardamu believes causes violence and warfare: "Serais-je donc le seul lâche sur la terre? pensais-je. Et avec quel effroi! ...Perdu parmi deux millions de fous héroïques et déchaînés et armés jusqu'aux cheveux?"204 Here, Bardamu laments that he could possibly be the last of the lâches. Through his character's reaction to war, Céline intimates that having more lâches and fewer fous heroiques would not be a terrible situation. This reversal of meaning and cultural significance renders lâche a desirable term. Now, the lâche are the only ones brave enough to circumvent armed conflict and cultivate life while the fous heroiques, as the term indicates, foolishly seek violence and its consequence: death.

Much like Bardamu's departure for the war-which occurs on a lark, as a joke or a dare - he only performs pre-war French masculinity up to and in the service of his entry

\footnotetext{
202 See Figure 33.

${ }^{203}$ Céline, Voyage au bout, 12. "So will I be the only coward on earth? I thought. And with what dread!"

${ }^{204}$ Ibid, 12. "So will I be the only coward on earth? I thought. And with what dread! ...Lost among two million heroic madmen, unleashed and armed to the teeth?"
} 
into the conflict. Bardamu follows the military display freely by joining the military parade. He does so mostly to prove Arthur wrong, feeling pride in his lampoon of heroism — until the gates close behind him and he is trapped: “J'allais m'en aller. Mais trop tard! Ils avaient refermé la porte en douce derrière nous les civils. On était faits, commes des rats. ${ }^{.205}$ Céline's description of this scene is telling. He depicts Bardamu gleefully joining the parade as long as people are witness to his participation. Bardamu desires to be seen, and seen specifically as a hero. For Bardamu, heroism and masculinity are performances that require an audience. But as soon as the spectators ("les patriotes") begin to dissipate, Bardamu slowly realizes what lies behind the performance:

Il y en avait des patriotes! Et puis il s'est mis à y en avoir moins des patriotes. ...La pluie est tombée, et puis encore de moins en moins et puis plus du tout d'encouragements, plus un seul, sur la route. Nous n'étions donc plus rien qu'entre nous? Les uns derrière les autres? ...En résumé, que je me suis dit alors, quand j'ai vu comment ça tournait, c'est plus drôle! C'est tout à recommencer! "J'allais m'en aller. Mais trop tard! Ils avaient refermé la porte en douce derrière nous les civils. On était faits, commes des rats." 206

Bardamu wants le regard de l'autre to see in him the hero he mimes, thus validating him in that role. He has never intended to enlist, merely to go along with the pomp and circumstance as long as it provided what his ego sought. This scene exposes that, for Céline, heroism only exists in le regarde de l'autre; it is only a performance for

${ }^{205}$ Céline, Voyage au bout., 6. "I was going to get out. But too late! They had already quietly closed the gate behind us civilians. We were trapped, like rats."

${ }^{206}$ Ibid, 6. "There were lovely patriots! And then there started to be fewer lovely patriots. ...The rain fell, and then less and less spectators and then even less encouragement, then not even one, on the road. So we were nothing but ourselves? One behind the other? ...In summary, what I said to myself then, when I saw how it turned out, it's no longer funny! Let's start it all again! I was going to leave. But too late! They had quietly closed the door behind us the civilians. We were trapped, like rats." 
others. This reappears later in the novel when, during a botched desertion attempt, Bardamu is wounded and returns to Paris, only to be glorified as a hero. The incongruity of the deserter's commendation for bravery is not lost on Bardamu; it further reinforces his opinion of the absurdity of war and his desire to avoid such absurdity at all costs.

Bardamu's sustained performance of pre-war masculinity offers no respite from the trauma of battle, nor does it protect any of those who participate in it. Masculine performance ultimately fails Bardamu and leads him into a dysphoric state of mind. Bardamu thus sets out on a journey in search of hope. Each flight takes him to a new physical location with new cultures and different challenges and presupposes a fresh start that Bardamu will always, however, understand as false. His flights represent a series of rejections of traditional masculine behavior.

Bardamu is already suspicious of pre-war masculine behavior, specifically the hero myth. Céline's character does not seek to fill the shoes of the men or soldiers who have gone before. Instead, Bardamu holds in contempt all those who, as he does, march willingly off to war or support the hero myth: the pre-war masculine behavior that called upon the French man to willingly and enthusiastically sacrifice himself on the battlefield. This is his assessment before volunteering. The hero that Céline describes in Bardamu's words (see Footnote 18) holds no value for Bardamu, even before completing his hasty enlistment.

Alors on a marché longtemps. Y en avait plus qu'il y en avait encore des rues, et puis dedans des civils et leurs femmes qui nous poussaient des encouragements, et 
qui lançaient des fleurs des terasses, devant les gares, des pleines eglises. Il y en avait des patriotes! Et puis il s'est mise a y en avoir moins de patriotes. ${ }^{207}$

A little rain is all it takes to discourage the supporters of the supposed heroes. As soon as the rain begins, the civilians' encouragement of the soldiers evaporates. No longer convenient to cheer the hero and soldier, he is easily left behind, forgotten. The hero only exists when seen and when it is convenient to see him. Céline seems to ask: Once the streets are empty, once there are no more cheers or flowers, are there still heroes? When the crowd disappears, Bardamu has entered the collective unconscious with his fellow recruits and becomes an abstraction of war.

The parade of soldiers and recruits only exists as long as they are available to be seen. Thus, the function of the propaganda poster: to recall the soldier's plight to civilians who could not see them. The posters provide a visual testimonial to the myth of the hero and soldier, the Frenchman's duty. Additionally, the posters endorse war and soldiering as a national good. Much like the propaganda image of the soldiers (see Figures 31, 34, and 35), the parade Bardamu joins is in full regalia. In addition, like the poster, the colonel is on horseback and the procession is led by a band. ${ }^{208}$ Céline seems to deliberately reference such posters and their disinformation. There is the necessity of $l e$ regard in the perception of the hero while pointing to the fallacy in doing so when Bardamu rails against the idea of war and duty (see Footnote 18) prior to his enlistment, yet he falls victim to the same propaganda. Bardamu's life appears to serve as a warning

\footnotetext{
207 Céline, Voyage au bout, 7. "So we walked a long time. There were more spectators than there were streets, and from inside civilians and their wives who urged us on, and who threw flowers from the terraces, in front of the stations, from full churches. There were lovely patriots! And then there started to be fewer lovely patriots."

${ }^{208}$ See Figures 31, 34, and 35.
} 
for those willing to follow the advice of the propaganda poster. However, the posters stop short of reality in the trenches and the frontline. Were the truth displayed on the same posters, surely the civilian population would not support warfare, as evidenced in Bardamu's relationships with Lola and Musyne. The two women have reason to understand the brutality of the war, as both encountered and served wounded soldiers. Bardamu explains:

Les femmes surtout demandaient du spectacle et elles étaient impitoyables, les garces, pour les amateurs déconcertés. La guerre, sans conteste, porte aux ovaires, elles en exigeaient des héros, et ceux qui ne l'étaient pas du tout devaient se présenter comme tels ou bien s'apprêter à subir le plus ignominieux des destins. ${ }^{209}$ Accordingly, both women push Bardamu to return to battle without having a deeper understanding than the propaganda posters would advise:

Musyne désirait fort aussi, comme Lola, que je retourne au front dare-dare et que j'y reste et comme j'avais l'air de tarder à m'y rendre, elle se décida à brusquer les choses, ce qui pourtant n'était pas dans sa manière. ${ }^{210}$

Neither woman demonstrates understanding for a young soldier they see as capable of completing his heroic duty by returning to battle. As Bardamu notes, it was out of character for Musyne to be "brusque" about anything. Rather than show patience or understanding, she abandons Bardamu for Argentinian soldiers who demonstrate masculinity and fit the hero myth she and Lola seem to prefer.

\footnotetext{
${ }^{209}$ Céline, Voyage au bout, 100. "Women especially asked for entertainment and they were merciless, bitches, for disconcerted amateurs. The war, undoubtedly, carries to the ovaries, they demanded heroes, and those who weren't at all had to introduce themselves as such or prepare to undergo the most ignominious of destinies."

${ }^{210} \mathrm{Ibid}, 90$. "Musyne also wanted, very much, like Lola, for me to return to front double-time and that I stay there and since I seemed to be late in getting there, she decided to rush things, which however wasn't her way."
} 
After Bardamu's experience in war, he sees parades, propaganda, and heroism as folly. As he watches many young men braver than him fall, he survives the war by running and hiding. He punctures the propagandized hero myth by describing the unimaginable death toll of war and dehumanization of the soldier. For Bardamu, the necessary result of this equation is the destruction of the hero myth and the adoption of the lâche. Accepting this label is an active and complete rejection of French cultural masculine norms. Finally, the rejection of the hero is also a rejection of traditional French masculinity. For Bardamu, it is not that the hero will die; it is that the hero must die while the lâche will survive. If the hero does not die, both literally and symbolically, then war, death, and destruction will win.

\section{Fight or Flight}

Until Bardamu's departure for the military, he was not consciously aware of his role in the gendered dialectic of WWI France. In his statements to Arthur prior to enlisting, Bardamu presumes the existence of a powerful hierarchy, which disregards his personal being and welfare. Bardamu plays out what he supposes happens during combat: The "masters," or the men with money and power, entertain women while ordering soldiers, telling them “c'est la guerre!" and discussing unnamed countries:

On est en bas dans les cales à souffler de la gueule, puants, suintants des rouspignolles, et puis voilà! En haut sur le pont, au frais, il y a les maîtres et qui s'en font pas, avec des belles femmes roses et gonflées de parfums sur les genoux. On nous fait monter sur le pont. Alors, ils mettent leurs chapeaux - 7 - haut de forme et puis ils nous en mettent un bon coup de la gueule comme ça: "Bandes de charognes, c'est la guerre! qu'ils font. On va les aborder, les saligauds qui sont 
sur la patrie $\mathrm{n}^{\circ} 2$ et on va leur faire sauter la caisse! Allez! Allez! Y a de tout ce qu'il faut à bord! Tous en chœur! Gueulez voir d'abord un bon coup et que ça tremble: Vive la Patrie ${ }^{\circ} 1$ ! Qu'on vous entende de loin! Celui qui gueulera le plus fort, il aura la médaille et la dragée du bon Jésus! Nom de Dieu! Et puis ceux qui ne voudront pas crever sur mer, ils pourront toujours aller crever sur terre où c'est fait bien plus vite encore qu'ici! $!^{211}$

Céline is voicing the commands of those who are in control of the soldiers, those who participate in reproducing the heroic masculine "norm." In reproducing the gendered, or heroic masculine, identities, Céline is involved in violence against male bodies, with the soldiers forced to internalize this specific performance by yelling. The author does this farcically, telling the soldiers that whoever yells the loudest will get a medal and an almond dragée shaped like crucified Jesus. I believe Céline uses this imagery to highlight the absurdity of the situation. Yelling is far from an act of heroism, yet the soldiers receive a medal, an honor, for doing so.

The almond dragée is another element of the absurd that Céline has added to this scene. Incongruous within this context, almond dragées are traditional for weddings, births, and other celebrations. More than this, the candy is not a plain almond dragée but one shaped like crucified Jesus, lending a decidedly religious tone to a scene of violence. Céline seems to intimate that training soldiers is not an entirely secular event but one

${ }^{211}$ Céline, Voyage au bout, 6. "We are down in the stalls breathing from our mouths, stinky, soaking to the balls, and then that's it! Up on the deck, cool, there are the masters and who do not worry, with beautiful pink women, swollen with perfumes, on their knees. We are put on the bridge. So they put their hats -7-top hats and then they kick us up like this: "Bands of carrion, it's war! that they do. We will approach them, the bastards who are from nation $\mathrm{n}^{\circ} 2$ and we will blow them up! Come on! Come on! There's everything you need on board! All together! Shout, give it a good shot and see that it trembles: Long live nation $\mathrm{n}^{\circ} 1$ ! Let us hear you from afar! Whoever shouts loudest, he will have the medal and the almond dragées of good Jesus! For God's sake! And then those who will not want to die on sea, they can always go to die on land where it is done much faster." 
tainted by religious fervor, thus "blessing" the practice as something almost spiritual. Not only would the soldier to yell the loudest be honored with a medal, but he would be "blessed" with the Jesus dragée.

Céline leaves Bardamu's sarcastic speech not tied to any one country. I suggest there are two reasons for this. First, Céline is suggesting that the standards to which soldiers must meet are the same, no matter the location or culture. Second, in leaving these nations nameless, Céline declares that Bardamu has no desire to advocate for the victory or defeat of any particular nation. An open-ended speech such as this could be applicable at any time or place with the same results.

\section{Hallucinations: The Galley Ship and Bardamu}

Later, when Bardamu sails by galley ship from the fictional African colony of San Tapeta to the Eastern Coast of the United States, he hallucinates that he has been purchased by the captain and is on a slave ship. The slave ship is an allegorical representation of social powers that condemn men to the hold like himself as prisoners or the enslaved. This hallucination evokes the beginning of the novel and Bardamu's first speech to Arthur (see Footnote 38). Men are incapable of independent thought or action and suffer for their blind faith while allowing those in power to manipulate and control them. Those considered the masters reside on the deck with beautiful, young women on their laps, recalling advertising posters that commodified young women, placing them in the possession of whoever bought the item for sale. ${ }^{212}$ The masculinity of the "masters" is not in question; they receive freedom from battle, women, and power. Those who suffer

\footnotetext{
${ }^{212}$ See Figures 2 and 4.
} 
below deck are only brought out to fight, suffering under the rule of the masters until sacrificed to the war effort. Céline voices the masters' words, those who watch and encourage the lowly men to fight each other like dogs for a few scraps - medals and trophies - thus enacting violence on the "prisoners," or men. As Bardamu states, the one who wails or yells the loudest will get the medal, reiterating the absurdity of war and the method by which power works to produce soldierism and heroism.

This speech to Arthur does more than establish Céline's opinions on warfare and the human condition: It portends Bardamu's destiny. In his hallucination, Bardamu suffers in a galley, rowing, with nothing to his name:

Mais enfin on est tous assis sur une grande galère, on rame tous à tour de bras, tu peux pas venir me dire le contraire! ...Assis sur des clous même à tirer tout nous autres! Et qu'est-ce qu'on en a? Rien! Des coups de trique seulement, des misères, des bobards et puis des vacheries encore. ${ }^{213}$

Bardamu leaves behind the small store he ran in Topo when he can no longer control it, unable to recover from his illness. How Bardamu ends up on a ship bound for the United States is impossible to know. His fever-addled mind makes no sense of events after leaving Topo, yet there is logic in his actions. While he hallucinates being enslaved and rowing aboard a galley ship, he accomplishes his earlier goal of getting as far from his failed store as possible.

The semantic choices here bring about images of enslaved peoples involved in the Atlantic slave trade between Africa and North America: individuals in "une grande

\footnotetext{
${ }^{213}$ Céline, Voyage au bout, 6. "But finally we are all seated in a large galley, we are all rowing, you can't come and tell me the opposite! ... Sitting on nails even pulling all of us! And what do we have? Nothing! Only strokes of the cudgel, miseries, bastards and then tricks again."
} 
galère," who suffer from "Des coups de trique." Danielle Racelle-Latin contends that the use of ships in Voyage au bout de la nuit is a metaphor:

Force est de remarquer toutefois que cette galère anachronique répond moins à l'intention de dénoncer le colonialisme comme un vestige scandaleux de l'Ancien Régime que de stigmatiser l'asservissement d'une Europe moderne, démocratisée, face au jeune impérialisme Américain. ${ }^{214}$

Others have argued that the galley ship is a part of an elaborate hallucination.

\section{Michael Tilby proposes:}

The reader has earlier realized that his [Bardamu's] claim to be a galerien is a fabrication. In this passage the suggestions of fever and madness point towards the conclusion that his account is coloured by a hallucinatory tendency. ${ }^{215}$ I agree with Racelle-Latin and Tilby that the ship is not only a metaphor for Europe coming into contact with a young imperialist America, but that this passage in the galley ship is a hallucination. Bardamu makes no secret of his scorn for capitalism's debasement of the average man. As mentioned by Nicholas Hewitt, this scorn "is translated throughout the novel into a strong anti-democratic stance, by which bourgeois democracy is viewed as a mere fraud." 216 Thus, his perspective is that the common man is therefore enslaved not only by capitalism but modernity in general, the brightest beacon of which is America.

${ }^{214}$ Danielle Racelle-Latin, "Symbole et métaphore idéologique dans Voyage au bout de la nuit," Australian Journal of French Studies 13, 93. "It must be noted, however, that this anachronistic galley responds less to the intention of denouncing colonialism as a scandalous vestige of the Ancien Regime than to stigmatizing the enslavement of modern, democratized Europe in the face of young American imperialism."

${ }^{215}$ Michael Tilby, "Celine and the Anarchical Text: Bardamu Recounts his First Glimpse of New York," in The Art of Reading, Essays in Memory of Dorothy Gabe Coleman, Phillip Ford et al. ed. (Cambridge: Cambridge French Colloquia, 1998), 181).

${ }^{216}$ Hewitt, Nicholas, The Golden Age of Louis-Ferdinand Céline (Oxford: Berg Publishers, 1987), 61. 
Viewed in terms of capitalism, one cannot ignore the similarities in this trajectory to that of the enslaved populations of West Africa brought to America. Although not experiencing a complete hallucination, Bardamu does travel by ship, which is visible in the bay after the voyage; the deeper meaning, to him, was that of absurdity. He felt sent to America by the colonial government, which was, in effect, acting as his master. The government sent him away ostensibly for his own good, not based on his desires. This trip and the galere that carried him signify Bardamu's loss of agency and freedom, which he ties to his status as a poor person. Earlier, when first sent to Africa, he muses:

On m'avait donc embarqué la-dessus, pour que j'essaye de me refaire aux Colonies. Ils y tenaient ceux qui me voulait du bien, à ce que je fasse fortune. Je n'avais envie moi que de m'en aller, mais comme on doit toujours avoir l'air utile quand on est pas riche et comme d'autre part je n'en finissais pas avec mes études, ça ne pouvait pas durer. ${ }^{217}$

Because Bardamu is a man, he must be useful, and those who would be his masters want "du bien" for him. As he has not yet finished his medical studies, he has seemingly no choice but to pretend to agree with the demands and expectations of prewar French masculinity. This requires a career "on doit avoir l'air utile," or usefulness, which, according to pre-war French masculinity, would also lead to his future wealth: "’̀̀ ce que je fasse fortune." Bardamu comes close to making a direct comparison between standards of pre-war French masculinity and enslavement. The absurdity in the parallels

\footnotetext{
${ }^{217}$ Céline, Voyage au bout, 111. "I was put on the ship so I could try to get back to the Colonies. They kept those who wished me well, so that I would make a fortune. I only wanted to go away, but since once always has to seem useful when one isn't rich and on the other hand since I wasn't finishing my studies, it couldn't last."
} 
that Bardamu sees in his modern condition and the historical traffic of enslaved Africans drives his hallucinatory description of his sea voyage to New York.

Although a semiautobiographical account of Céline's participation as a soldier in WWI, the novel also served as a pulpit from which to share his feelings about war. War and violence, however, are not the only themes Céline discusses in this text. Through Bardamu's efforts, flights, and ponderings, the author also reflects on culture, colonialism, and gender. Céline has, much like Colette, created a character who is unable to use what he learned in his training in pre-war French masculinity to survive in a changed and modern world.

\section{CONCLUSION}

WWI created disruptions at every level of French life. Deep-seated anxieties over gender came to light as the nation grappled with war, upending the traditional divisions

of gender. Masculinity, in particular, was seen as fragile, having been weakened by prior defeat and what was seen as years of excess. This necessary gender swap coincided most clearly with the outbreak of war but also amid nationalistic fears of defeat. This fear was fixed upon the Frenchman, not on his abilities or skills, but his very nature and perceived weaknesses. As the only citizens and eligible soldiers, the men carried the weight of not only the defense of the nation but the future of French masculinity.

The propaganda poster transitioned from advertising with lovely young women to promote a different kind of normative agenda, replacing the women with soldiers in uniform, depicted either on the battlefield or on leave with family. The propaganda had a few goals, the first being to cause the audience to consume ideas rather than goods. The second goal was to make viewers identify with the nation's status, appealing to their 
sense of duty or patriotism. Finally, the third goal was to alter the viewing public's behavior to accommodate wartime needs. The propaganda poster was a means to convince viewers of the legitimacy of the imagery, engaging the viewer's sympathy, anger, and sense of duty while mobilizing donations and service.

With fears of weakness in the background, the propaganda poster employed heteronormative and matrimonormative imagery. This imagery called upon men to fight and women to await the men's return. ${ }^{218}$ This rather simplistic portrait proved to be a fiction of the era. The most basic of wartime needs transposed gender roles in work and home environments. The propagandized call to duty did not include a similar call for women to stay home or to wait. Instead, the war relied on women to work-and not just work, but to assume men's jobs. Women working outside the home in what were traditionally men's jobs added another layer to the insecurity over French masculinity. This is just one example of changes that the war demanded of the French population.

War propaganda pushed a specific vision of French society that was both heteronormative and matrimonormative. Figures 23 and 25 show the expectation for a heterosexual relationship. In addition, the theme of the male fighting while the female waits for him is apparent. As the war effort continued, the messages did not change; instead, they refocused, continuously targeting masculine performances. In Figures 10 and 11 , gendered performances clearly illustrate the expectation that masculinity was warrior-like, composed in the face of danger, leaping out of trenches to confront enemies. This warrior-man was to selflessly confront danger, marry, and reproduce while

\footnotetext{
${ }^{218}$ See Figure 23.
} 
supporting his family. The images and ideas disseminated from the posters left little room for alterity in gendered performances.

The novels discussed in this study, Chéri, La Fin de Chéri, Voyage au bout de la nuit, and L'Immoraliste, stand in opposition to the propaganda posters (read: French society's inadequate offerings). The gendered performances in these four novels allow for alternative and divergent gender performances. The WWI propaganda poster left no room for deviation, whereas the novels centered around the lives of individuals who did not conform to the heteronormative and matrimonormative society surrounding them. In presenting self-determined gender performances, Colette, Céline, and Gide call the WWI propaganda poster and its subjects into question. At the same time, the literary space created by these authors is in itself the presentation of a "norm." The three novelists countered the propagandized norms with examples of success, failure, heterosexuality, homosexuality, men, and women. The result is that the normative standards encountered, no doubt by the authors themselves as French citizens and soldiers during WWI, were shown to be fiction.

Throughout this study, it is apparent that these authors not only sought to counter the messages transmitted by the propaganda poster, but to create space for selfdetermined gendered performances. Michel, Gide's protagonist, struggles to recognize his authentic self. He must battle the standardized forces of French culture, both heteronormative and matrimonormative, to identify a performance and expression of self that liberates him. Ultimately, however, Michel finds he cannot be liberated. No culturally approved performance of masculinity is available to which he can adhere, and his own creation indirectly, or perhaps directly, causes his wife's death. 
Much like Gide, Colette provides a view of pre-WWI gender performance through Léa, Chéri, Charlotte, and Edmée. Colette’s protagonist, Chéri, is a study on preWWI masculinity, with heteronormative and matrimonormative standards applied to his life. Unlike Gide, Colette follows Chéri with La Fin de Chéri, which treats the eponymous character's return from the war as heroic. Seeking to return to his pre-WWI practice of masculinity, Chéri finds his pre-war world no longer exists; as such, his practice of masculinity is no longer relevant. Colette's characters embody genders from female masculinity to traditional femininity and masculinity, as well as performances that cover the gender spectrum. Edmée, Chéri’s formerly compliant and docile young wife, has developed a feminine practice that leaves her husband feckless and adrift. Charlotte, Chéri's mother, has adopted male styles of dress and cropped her hair short. She is no longer recognizable as a woman to Chéri. These formerly marginalized characters have not only altered their performance of femininity and female masculinity, but have relocated their practice from the margins of society.

Céline provides a vision of lâche masculinity in Bardamu, who appears to perform traditional French masculinity until he volunteers for the military, where he realizes he is a coward. He labels himself as such, as he would prefer to live and hide from the violence than be a heroic fool who dies. Through his flight across countries and continents, he stays true to his cowardice, pulling away from work, commitments, and love, fleeing the decay and death he sees in the world. Bardamu flirts with conformity much like Michel in L'Immoraliste. Rather than pretending to comply with heteronormativity as Michel would, Bardamu conforms by dedicating his faith and effort 
to curing a young child. This final attempt to right the world fails, showing Bardamu once again that the world is rotten and his cowardice justified.

Each novel presents marginalized characters who shift their position, both in terms of the gender spectrum and the center versus the margin of society. The characters who affect these relocations are those with divergent and alternative gender performances. Beginning at the margins and lacking agency, characters such as Edmée and Charlotte move to the center or to a place of normativity and agency, leaving characters such as Chéri displaced and impotent. Chéri, the heretofore bourgeois gentilhomme and wealthy man, is without purpose. His wartime heroism no longer matters, nor does his life and agency prior to the war; he finds himself at the margins. Feeling disenfranchised, Chéri ends his life surrounded by images of a past that cannot be recreated.

Michel finds himself in a contrary position. He must retain his position at the center, yet he finds his authentic self analogous to those socially considered in the margins: the colonized, the poor, and the morally corrupt. His effort to maintain his position at the center leads to cloaking, as he hides his homosexuality.

The four novels complement one another in their treatment of alterity. Each author presented facets of life as lived in pre-WWI and WWI France, revealing a complicated and intricate vision of gendered practices and performances while soundly disrupting the heteronormative and matrimonormative messages of the propaganda posters. The parallelism of these works does more than create a scandal or a fictional account of the war: It creates space for alterity and divergence. 


\section{FIGURES}

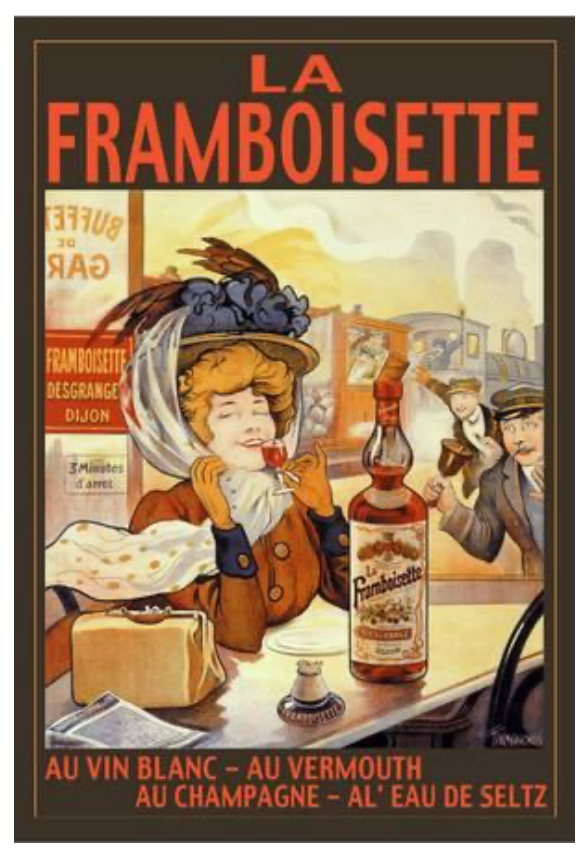

Figure 1

La framboisette

Francisco Tamagno (1905)

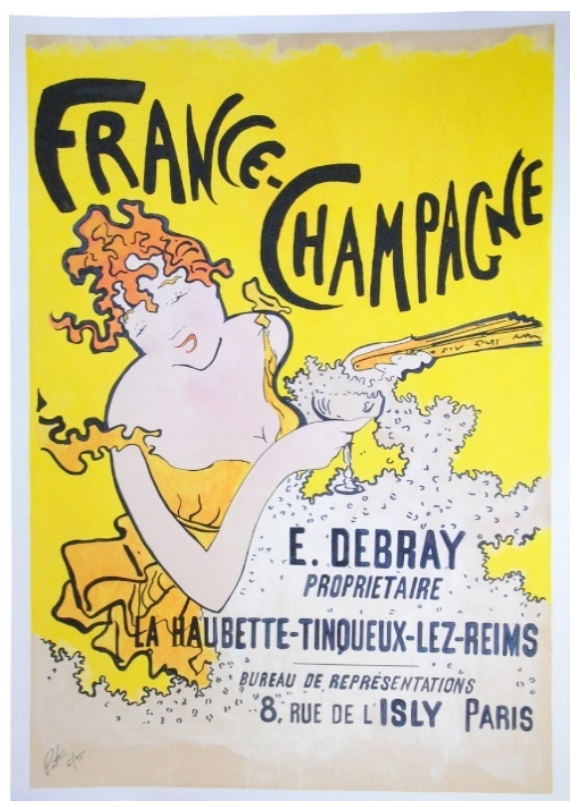

Figure 2

France-Champagne

Pierre Bonnard (1891) 


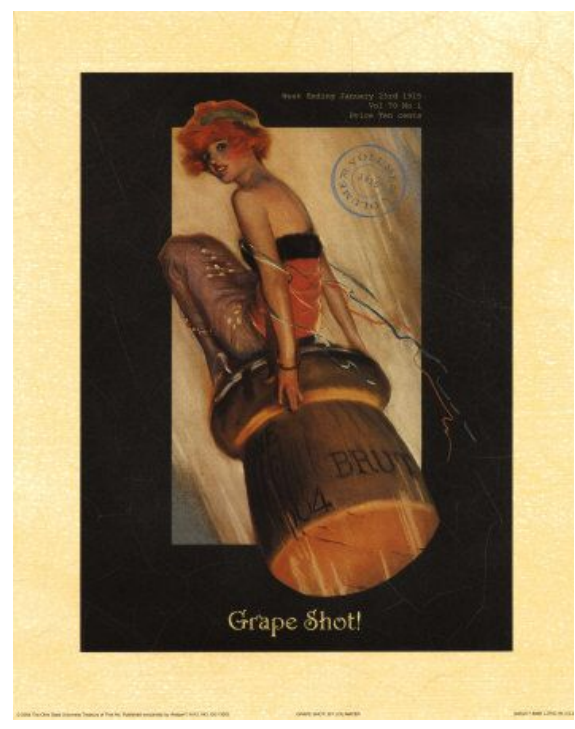

Figure 3

Grape Shot Brut

Lou Mayer (1915)

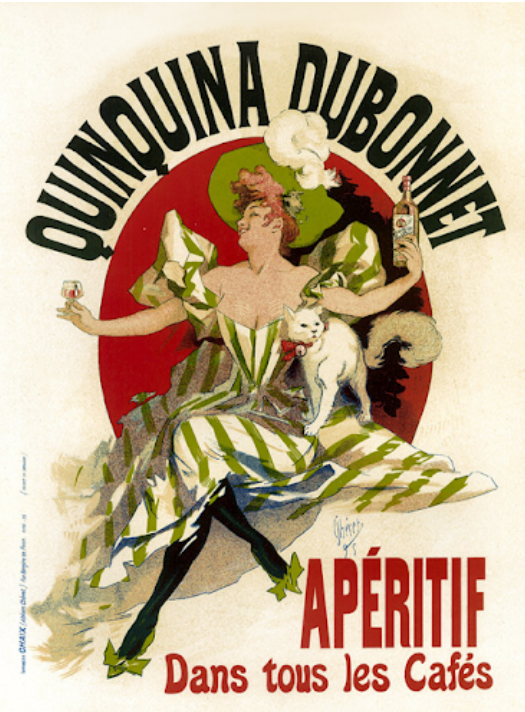

Figure 4

Quinquina Dubonnet Aperitif Jules Chèret (1895) 


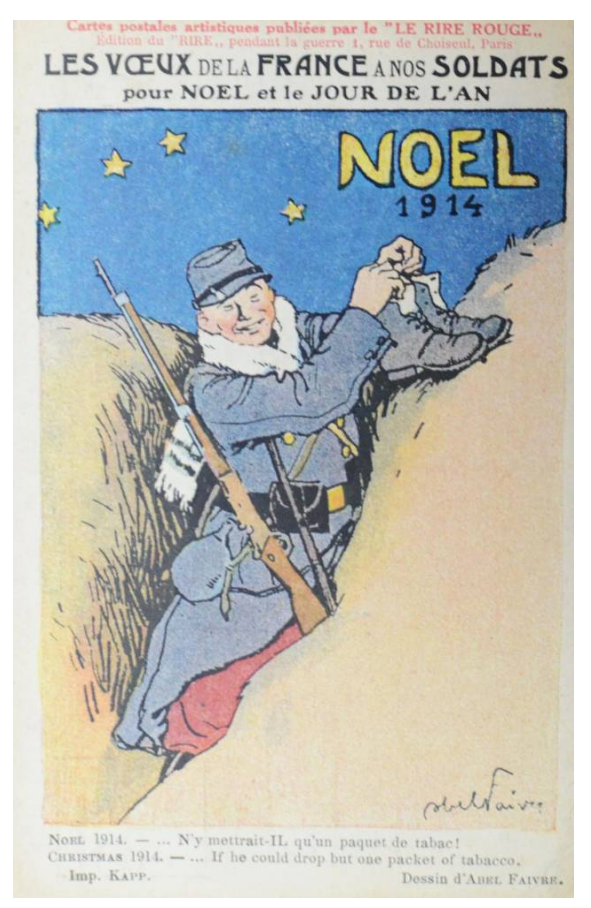

\section{Figure 5}

Postcard published by "Le Rire Rouge" for

Christmas 1914.

The wishes of France for her soldiers for

Christmas and New Years. Christmas 1914. If he could only drop but one packet of tobacco.

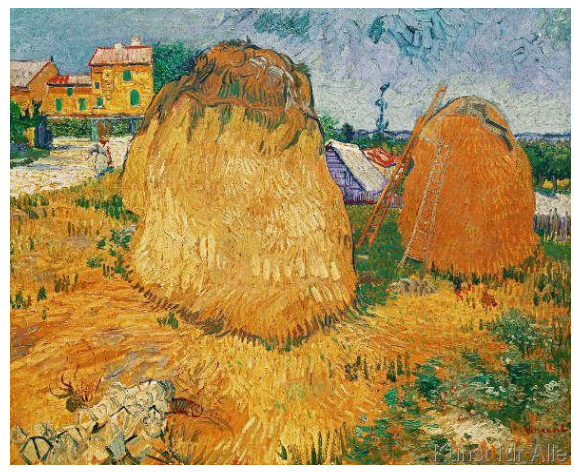

Figure 6

Haystacks in Provence

Van Gogh (1888)

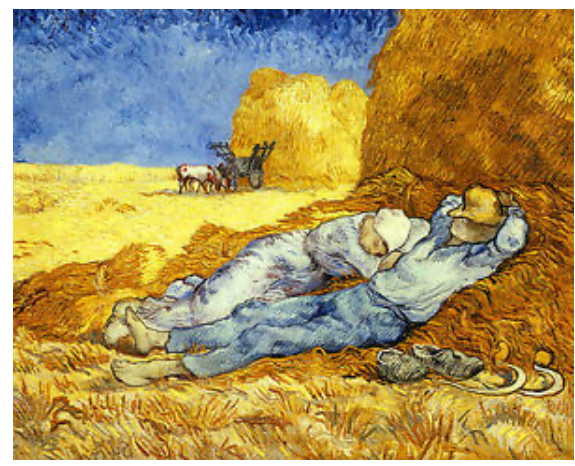

Figure 7

The Nap

Van Gogh (1889) 


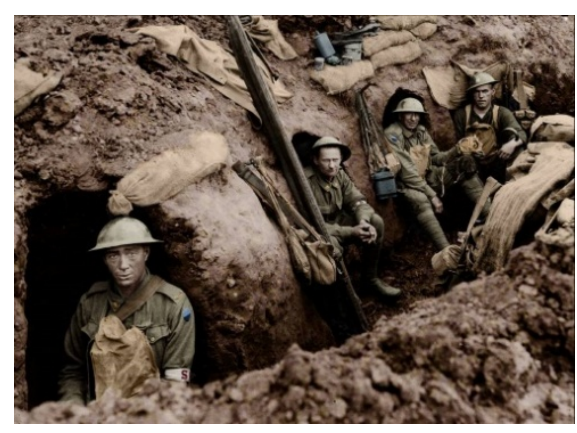

Figure 8

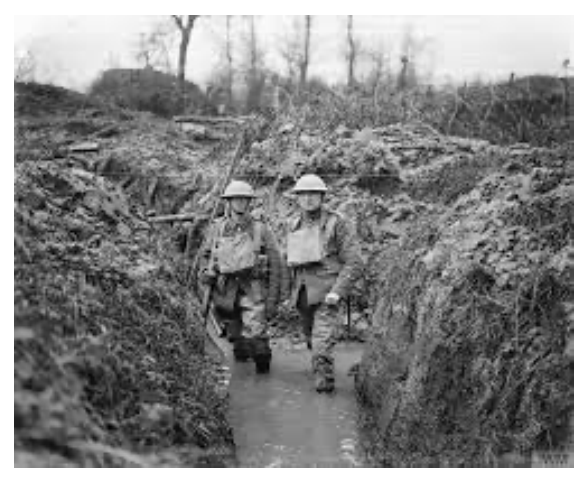

Figure 9

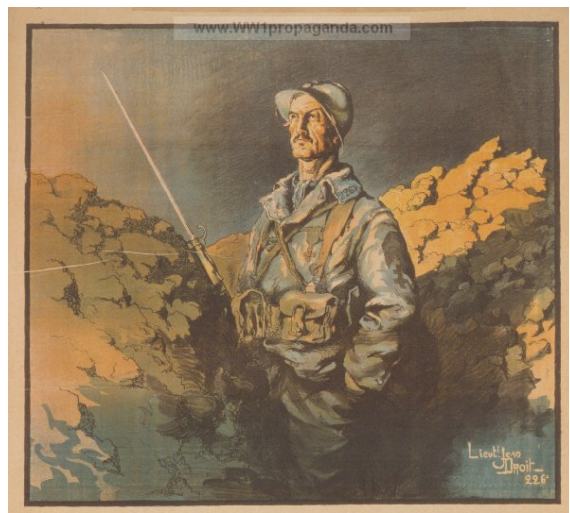

Figure 10

"The sunrise illuminates the trench where the standing soldier dreams of victory and his home. So that he can assure one and return to the other. Subscribe to the 3rd National Defense Loan." (1917)

DEBOUT DANS LA TRANCHÉE QUE L'AURORE ÉCLAIRE, LE SOLDAT RËVE Á LA VICTOIRE ET A SON FOYER. POUR OU'IL PUISSE ASSURER L'UNE ET RETROUVER L'AUTRE. SOUSCRIVEZ 


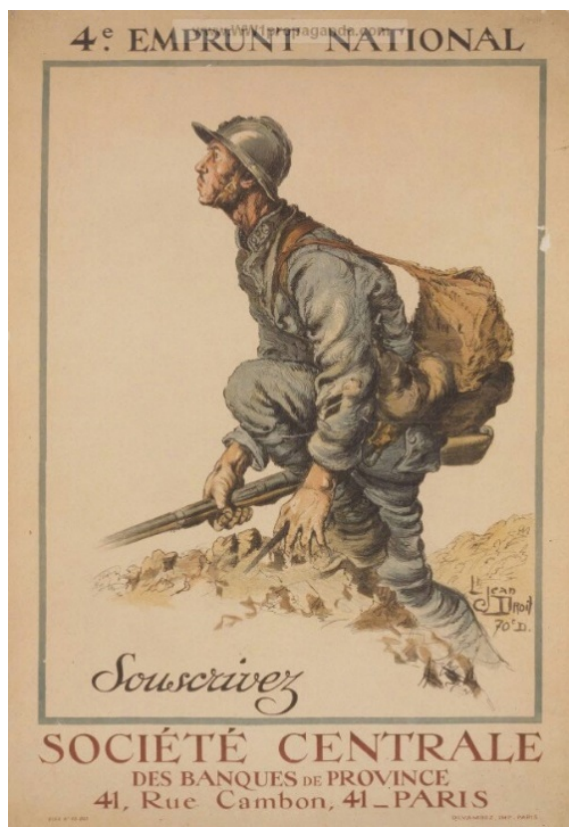

\section{Figure 11}

4th National Loan/Subscribe/Central Society of Banks of Province (1918)

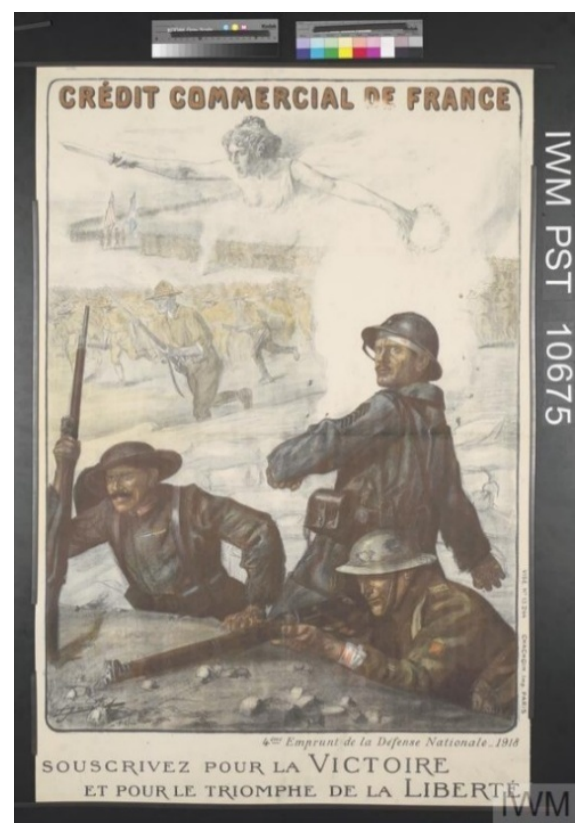

Figure 12

Commercial Credit of France/Subscribe for Victory and for the Triumph of Liberty - 4th

National Defense Loan (1918) 


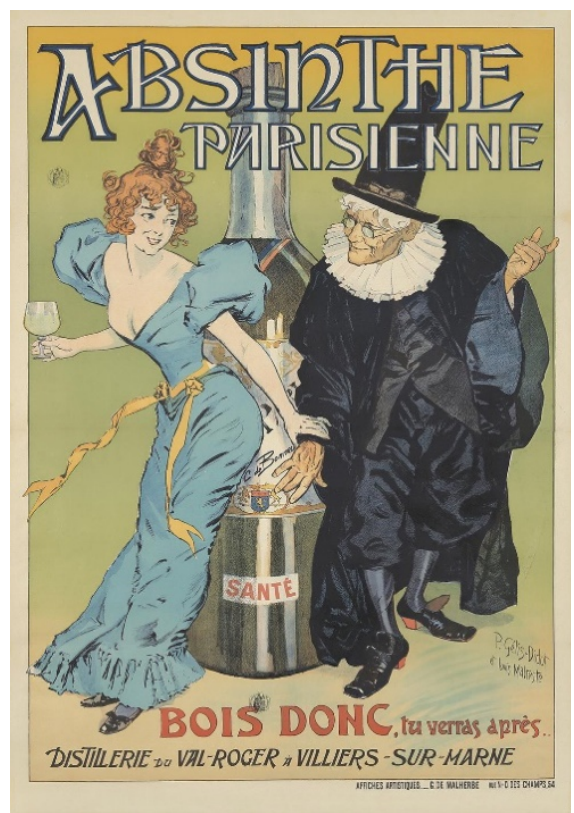

Figure 13

Absinthe Parisienne/“Drink Then, You Will See After"

Giles-Didot \& Malteste (1896)

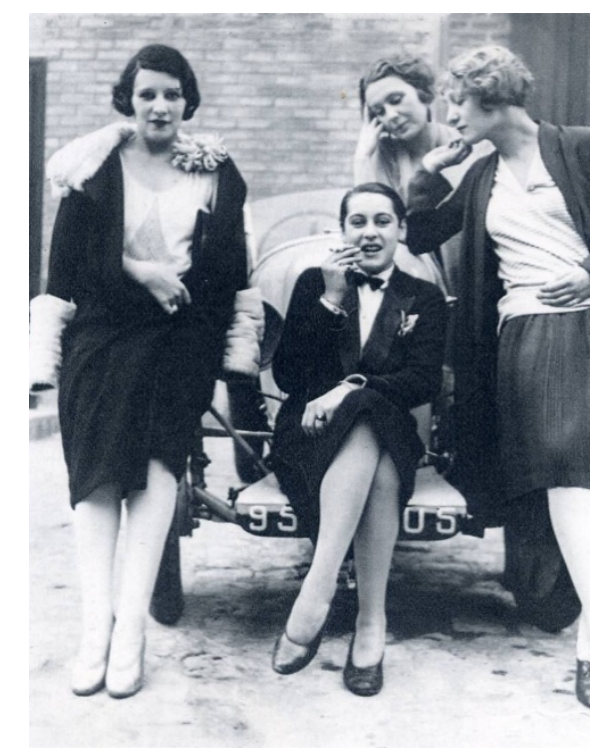

Figure 14 

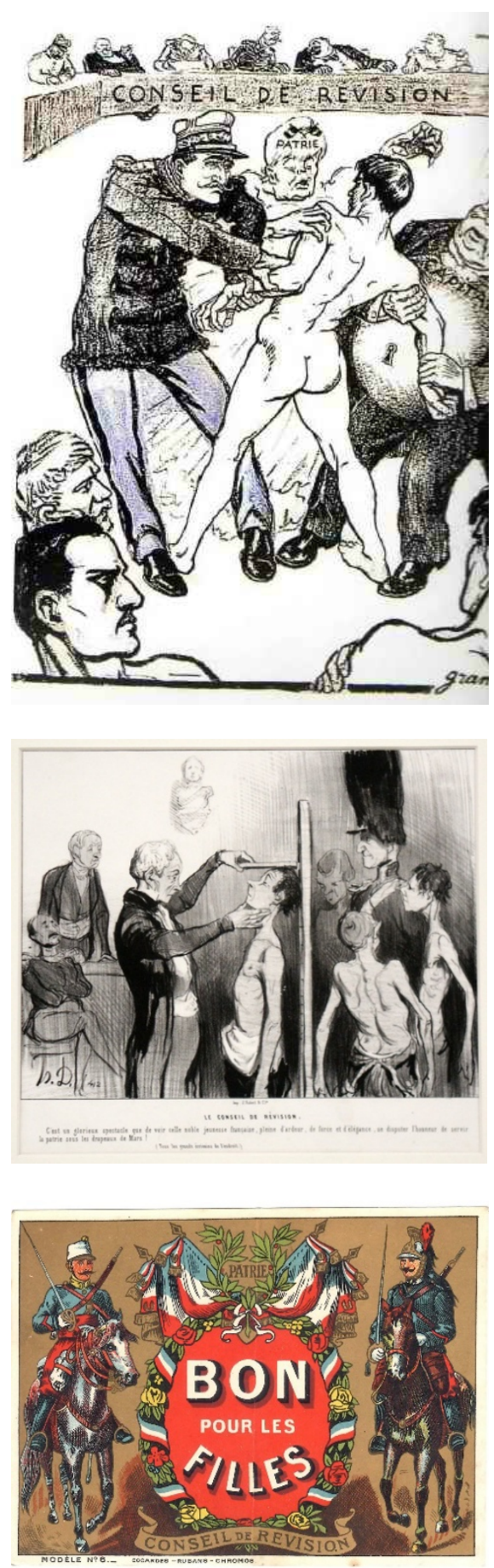

Figure 15

Conseil de Révision

Anti-conseil de révision cartoon.

Figure 16

Le conseil de révision/"The review board" Honoré Daumier (1842)

Figure 17

Bon pour les Filles/“Good for Women" 

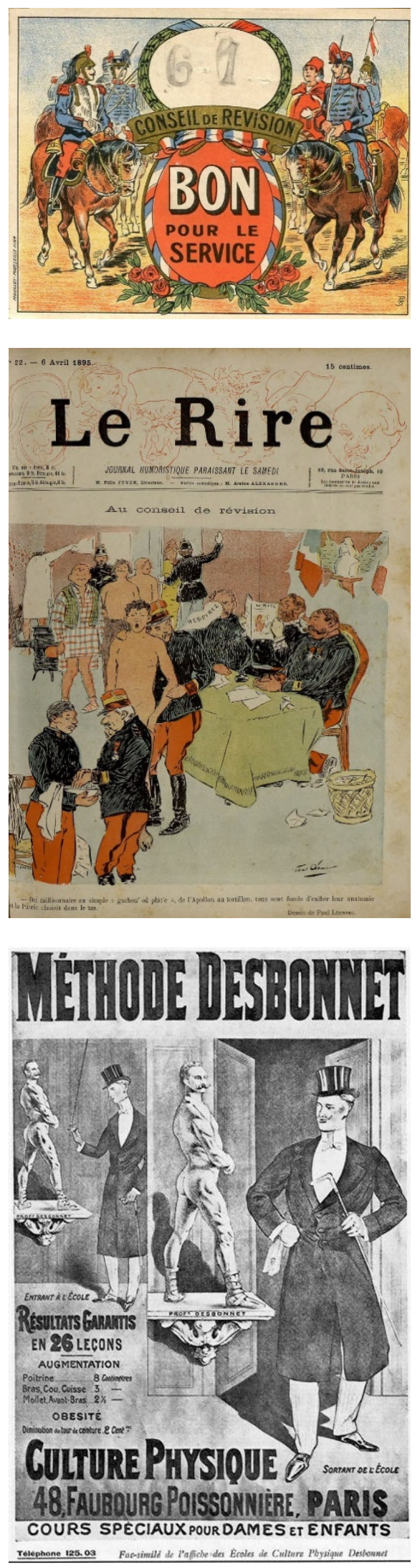

Figure 18

Bon pour les Service/“Good for Service”

Figure 19

Le Rire/"At the Review Board"

Paul Leonnec (1895)

Figure 20

Méthode Desbonnet/Results Guaranteed in 26 Lessons (1904) 

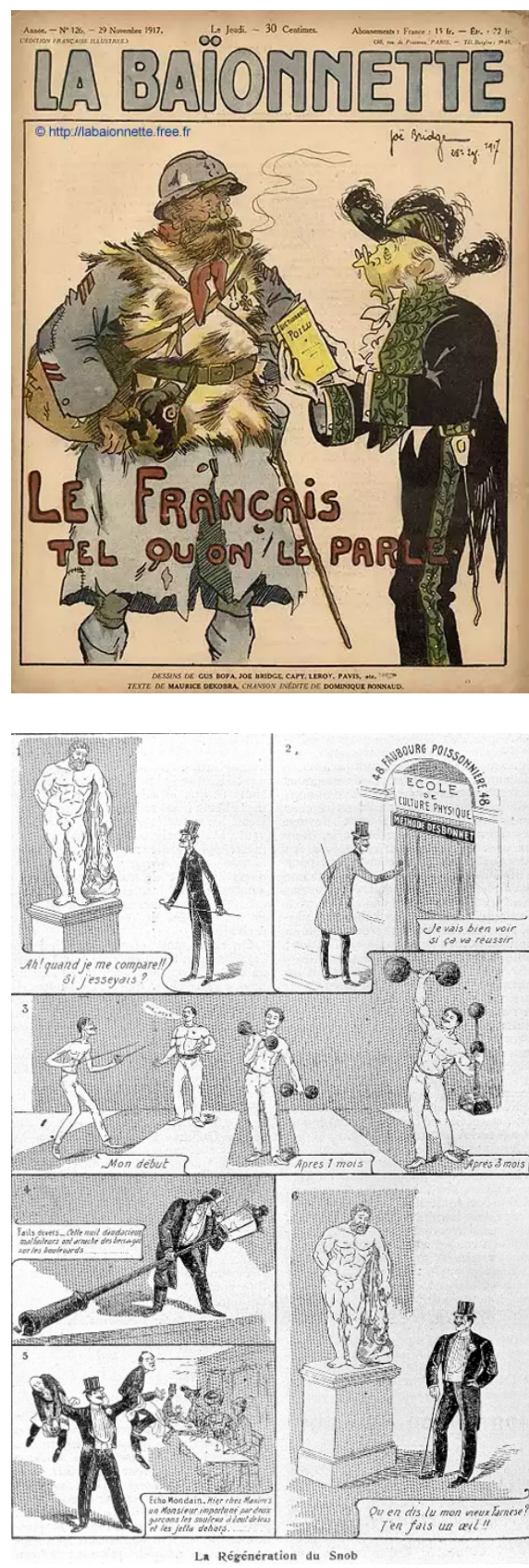

Figure 21

La Baïonnette, 29, November (1917)

Figure 22

La Culture Physique (1904)

"Régénération du Snob"

La Culture Physique, 1904, satire.

Credit: Wellcome Collection. Attribution 4.0 International (CC BY 4.0) 

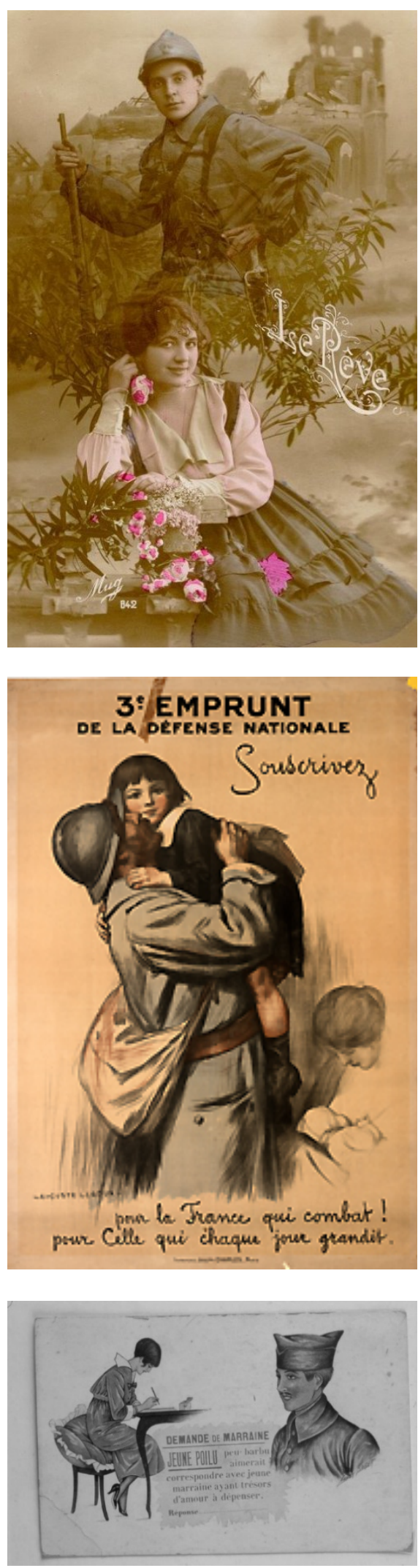

Figure 23

Le Rêve/The Dream

Nug 342 (1916)

Figure 24

"Third National Defense Loan - Subscribe!"

"For France who fights! For each little one who grows each day!

Auguste Laroux (1917)

Figure 25

"Request for Godmother - Young Soldier, hardly bearded would like to correspond with a young godmother possessing treasures of love to share Respond"

Xavier Sager (1915) 

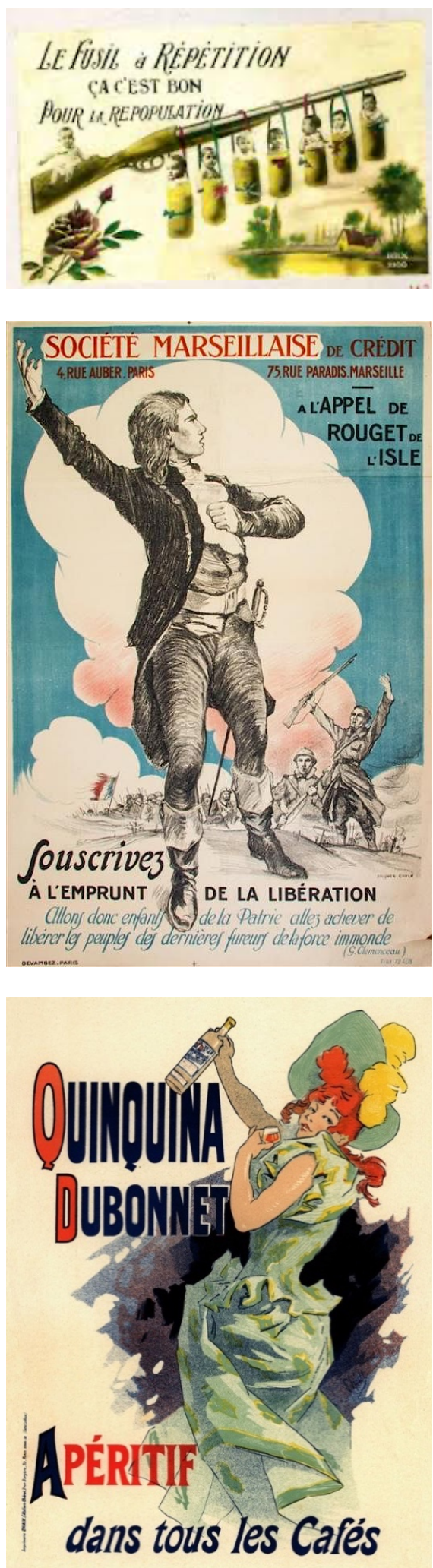

Figure 26

"The repeating rifle, it's good for repopulation" Rex 2100 (1915)

Ville de Paris - Bibliothèque Marguerite Durand

Figure 27

"Société Marseillaise de Crédit"

"At the call of Rouget de L'isle - Subscribe to the Liberation Loan"

1918

Carlu, Jacques, Artist. Société Marseillaise de Crédit. Souscrivez á l'Emprunt de la Libération. [Paris: Devambez] Photograph.

Retrieved from the Library of Congress

Figure 28

La rouquine

Jules Cheret (1895)

Quinquina Dubonnet Apériti/In Every Café 

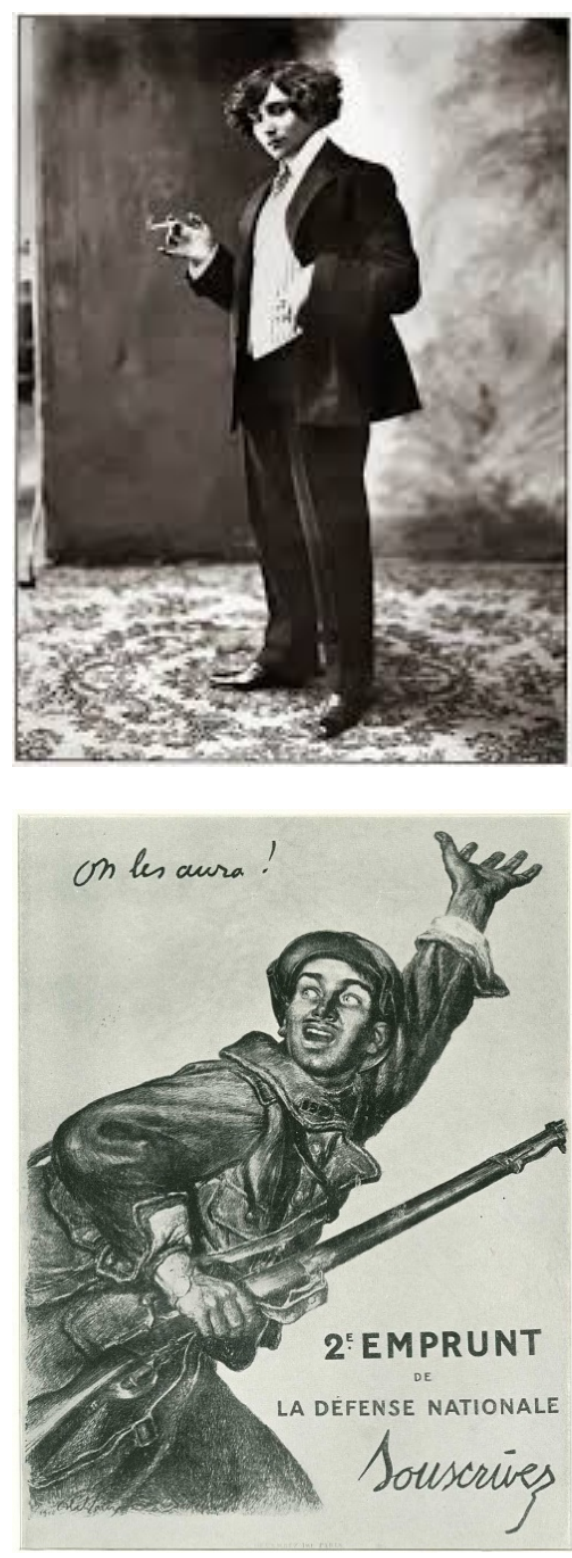

Figure 29

Sidonie Gabrielle Colette

photographed by Henri Manuel (c. 1909)
Figure 30

"We will get them!'/2nd Loan for National Defense/Subscribe

Jules Able Faivre (1916)

The propaganda artists' imagining of the enthusiastic soldier running into battle and seemingly enjoying the pursuit and idea of attacking and killing the enemy is evoked in this quote from Celine. The soldier portrayed is bright eyed and without concern for his own safety as he is upright out of the trench's protection. 


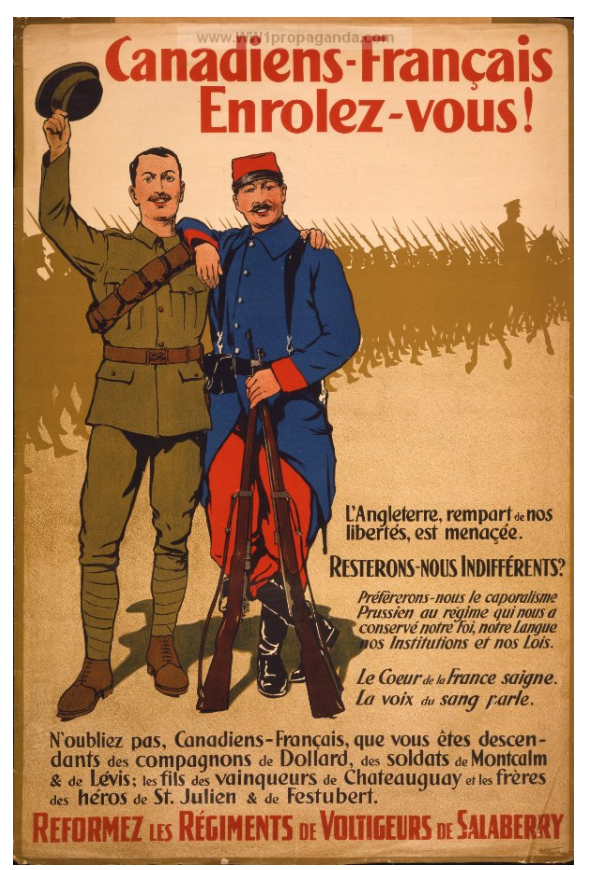

Figure 31

"French Canadians Enlist!

England, rampart of our liberty, is menaced. Will we stay indifferent?"

AH. Hider (1915)

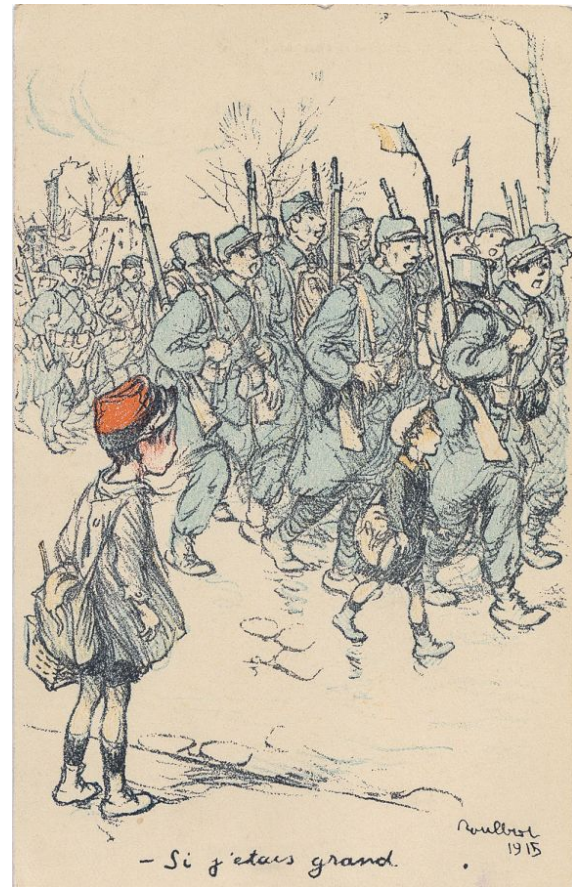

Figure 32

"If only I was bigger."

Boulbot (1915) 


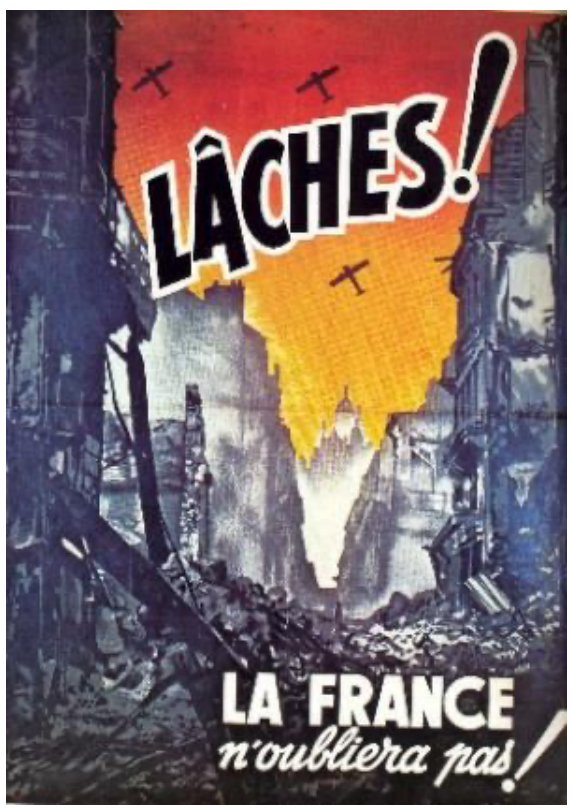

Figure 33

"Cowards! France will not forget!"

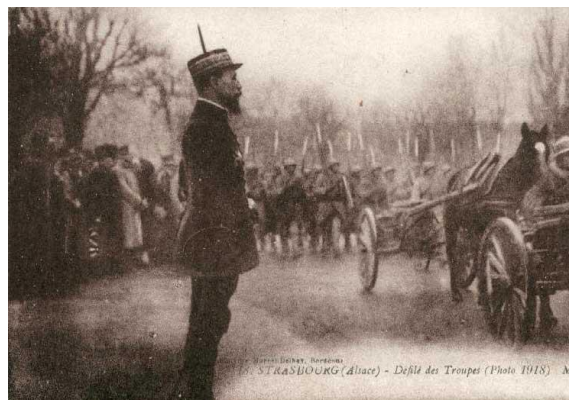

Figure 34

M.D.

Parade of troops (1918)

Strasbourg (Alsace)

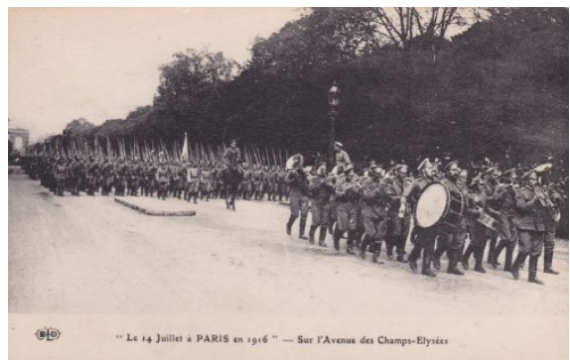

Figure 35

"July 14th in Paris, 1916, on Avenue Champs Elysees" 


\section{BIBLIOGRAPHY}

\section{WORKS CITED}

Barbusse, Henri. Feu (Folio Plus Classique). French ed., Gallimard Education, 2007.

Beaujour, Michel. "Céline, artiste du laid,” The French Review 38 no. 2 (1964), 180-90.

Bederman, Gail. Manliness and Civilization: A Cultural History of Gender and Race in the United States, 1880-1917. University of Chicago Press, 1996.

Berger, John. Ways of Seeing: Based on the BBC Television Series. 1st ed., Penguin Books, 1990.

Biolley-Godino, Marcelle. L'homme objet chez Colette. Klincksieck, 1972.

Butler, Judith. Gender Trouble: Feminism and the Subversion of Identity. 1st ed., Routledge, 2006.

Céline, Louis-Ferdinand. Voyage au Bout de la Nuit. French ed., Assimil Gmbh, 2000.

Clayson, Hollis. Painted Love: Prostitution in French Art of the Impressionist Era. Yale University Press, 2003.

Colette, Sidonie-Gabrielle. Chéri. Translated by Stanley Applebaum, Dover Publications, 2013.

---. La Fin De Chéri. French ed., Flammarion, 1993.

Connell, R. W., and James W. Messerschmidt. "Hegemonic Masculinity.” Gender \& Society, vol. 19, no. 6, 2005, pp. 829-59.

Dalby, Louise Elliot. The Great War and Women's Liberation. Skidmore College Faculty Research Lecture, 1970. Saratoga Springs, NY.

De Beauvoir, Simone, Le Deuxième Sexe [The Second Sex], Gallimard Education, 1949. 
Dean, Carolyn J. The Frail Social Body: Pornography, Homosexuality, and Other Fantasies in Interwar France. University of California Press, 2000.

Descuret, Jean Baptiste Félix. La médecine des passions ou Les passions considérées dans leurs rapports avec les maladies, les lois et la religion. 2nd ed., Labé, 1844.

Fell, Allison. "Life after Léa: War and Trauma in Colette's Fin de Chéri." French Studies, vol. LIX, no. 4, 2005, pp. 495-507.

Fletcher, Anthony. “'Sticking it Out': Fear and Shell Shock," in Life, Death, and Growing Up on the Western Front. Yale University Press, 2013.

Fussell, Paul. The Great War and Modern Memory. Sterling Publishing Company, 1975. Garelick, Rhonda K. Rising Star: Dandyism, Gender, and Performance in the Fin-desiècle. Princeton University Press, 1998.

Gide, André. L'Immoraliste. Gallimard, 1972.

Gilbert, Sandra M. "Soldier's Heart: Literary Men, Literary Women, and the Great War." Signs: Journal of Women in Culture and Society, vol. 8, no. 3, 1983, pp. 422-50.

Green-McManus, Lindsay. Performing Masculinity: Control, Manhood, and the Rhetoric of Effeminacy. University of Southern California Press, 2007.

Grossman, Dave. On Killing: The Psychological Cost of Learning to Kill in War and Society. Little, Brown \& Company, 2009.

Guerard, Albert. André Gide. Harvard University Press, 1951.

Halat, Rebecca. Un homme un vrai: Martial and Alternative Masculinities in French War Literature and Film. University of Minnesota, 2014.

Halberstam, Jack, Female Masculinity. Duke University Press, 1998.

Hewitt, Nicholas. The Golden Age of Louis-Ferdinand Céline. Berg Publishers, 1987. 
Higonnet, Margaret, “Authenticity and Art in Trauma Narratives of World War I." Modernism/Modernity, vol. 9, issue 1, 2002, 91-107.

---. Behind the Lines: Gender and the Two World Wars. 1st ed., Yale University, 1987.

Lucey, Michael. Never Say I: Sexuality and the First Person in Colette, Gide, and Proust. Duke University Press Books, 2006.

Margueritte, Victor. La Garçonne. Flammarion, Paris, 1922.

Moblo, Brandon. "Failed Men: The Postwar Crisis of Masculinity in France 1918-1930." Student Summer Scholars, 2008.

Nye, Robert A. Masculinity and Male Codes of Honor in Modern France. University of California Press, 1998.

Pick, Daniel. Faces of Degeneration: A European Disorder, c.1848-c.1918. Reprint, Cambridge University Press, 1993.

Quinlan, Sean. The Great Nation in Decline: Sex, Modernity and Health Crises in Revolutionary France c.1750-1850. 1st ed., Routledge, 2016.

Racelle-Latin, Danielle. "Symbole et métaphore idéologique dans Voyage au bout de la nuit”, Australian Journal of French Studies, vol. 13, 1976, pp. 88-96.

Rai, Prathiba. "Review: Ways of Seeing." The Oxford Culture Review, 2017.

Reeser, Todd, and Lewis Seifert. Entre Hommes: French and Francophone Masculinities in Culture and Theory. 1st ed., Univ of Delaware Press, 2008.

Reynolds, Siân. France Between the Wars: Gender and Politics. Routledge, 1996.

Ridel, Charles, "Propaganda at Home (France)," International Encyclopedia of the First World War 1914-1918, A Global War - A Global Project. 
Roberts, Mary Louise. Civilization Without Sexes: Reconstructing Gender in Postwar France, 1917-1927. 1st ed., University of Chicago Press, 1994.

---. “Samson \& Delilah Revisited: The Politics of Women's Fashion in 1920's France.” The American Historical Review, vol. 98, no. 3, 1993, pp. 657-84.

Rogers, Adrienne. "Women and the Law." French Women and the Age of Enlightenment, edited by Samia I. Spencer, Indiana University Press, 1984.

Roth, Marty. "Advertising/Pornography/Art: The French Drink Poster.” The Journal of Popular Culture, vol. 48, no. 5, 2015, pp. 921-47.

Smith, Leonard. France and the Great War 1914-1918. Cambridge University Press, 2003.

Stanley, Adam C. Modernizing Tradition: Gender and Consumerism in Interwar France and Germany. LSU Press, 2008.

Surkis, Judith. Sexing the Citizen: Morality and Masculinity in France, 1870-1920. Reprint, Cornell University Press, 2011.

Tilby, Michael. "Céline and the Anachical Text: Bardamu Recounts His First Glimpse of New York." The Art of Reading: Essays in Memory of Dorothy Gabe Coleman, edited by Phillip Ford, Cambridge French Colloquia, 1998, pp. 173-82.

Tumblety, Joan. Remaking the Male Body: Masculinity and the Uses of Physical Culture in Interwar and Vichy France. 1st ed., Oxford University Press, 2012.

Weber, Eugen. France, Fin de Siècle. Harvard University Press, 1986.

Winter, Jay. Sites of Memory, Sites of Mourning: The Great War in European Cultural History. Cambridge University Press, 1998. 


\section{WORKS CONSULTED}

Coetzee, Frans, and Marilyn Shevin-Coetzee. Authority, Identity and the Social History of the Great War. 1st ed., Berghahn Books, 1995.

Fagley, Robert. Bachelors, Bastards, and Nomadic Masculinity: Illegitimacy in Guy de Maupassant and Andre Gide. Unabridged ed., Cambridge Scholars Publishing, 2014.

Frantzen, Allen. Bloody Good: Chivalry, Sacrifice, and the Great War. 1st ed., University of Chicago Press, 2003.

Hadlock, Philip G. "What Is a Coward? According to Céline's 'Voyage au bout de la nuit.”' Romance Notes, vol. 46, no. 2, 2006, pp. 235-42.

Halat, Rebecca. Un homme, un vrai: Martial and Alternative Masculinities in French War Literature and Film. Dissertation, University of Minnesota, 2014.

Iskin, Ruth E. (2003). Father Time, Speed, and the Temporality of Posters Around 1900. KronoScope. vol. 3, pp. 27-50.

Maher, Eamon. War and Rebellion in the Work of Louis-Ferdinand Célineand Sebastian Barry. War of the Words: Literary Rebellion in France and Ireland, edited by Eamon Maher and Eugene O’Brien, Rennes, TIR, 2010.

Meyers, Mark. "Feminizing Fascist Men: Crowd Psychology, Gender, and Sexuality in French Anti-Fascism, 1929-1945." French Historical Studies, vol. 29, no. 1, 2006, pp. 109-42.

Nye, Robert A. "Western Masculinities in War and Peace." The American Historical Review, vol. 112, no. 2, 2007, pp 417-38. 
Roberts, Mary Louise. Disruptive Acts: The New Woman in Fin-de-Siecle France. 1st ed., University of Chicago Press, 2005.

Rolland, Romain, et al. "Barbusse and the War Against War," Books Abroad, vol. 10, no. 1, 1936, pp. 2-4.

Salih, Sara, and Judith Butler. The Judith Butler Reader. 1st ed., Wiley-Blackwell, 2004. 
VITA

\section{Courtney L Webster}

webstercour@umsystem.edu

Courtney L Webster was born in Tulsa, Oklahoma, on February 22, 1978. They attended schools in both Oklahoma and Missouri before graduating from David H Hickman High School in 1996. The following year was spent in France as a Rotary Scholar. They graduated from Stephens College in Columbia, Missouri, in 2001 with a Bachelor of Arts in International Affairs and Politics. They worked for the United States Department of State until beginning a Master of Arts in Language Teaching at the University of Missouri-Columbia, completed in 2006. They completed a Ph.D. in French Literature in May 2021, dissertation title Propaganda, Masculinity, and the French Interwar Novel. 